\title{
Estudo clínico da eficácia da acupuntura no tratamento da discopatia intervertebral tóraco-lombar em cães
}

Dissertação apresentada ao Programa de Pósgraduação em Clínica Cirúrgica Veterinária da Faculdade de Medicina Veterinária e Zootecnia da Universidade de São Paulo para obtenção do título de Mestre em Medicina Veterinária

\section{Departamento:}

Cirurgia

Área de concentração:

Clínica Cirúrgica Veterinária

Orientador:

Prof $^{a}$ Dra. Júlia Maria Matera 
Autorizo a reprodução parcial ou total desta obra, para fins acadêmicos, desde que citada a fonte.

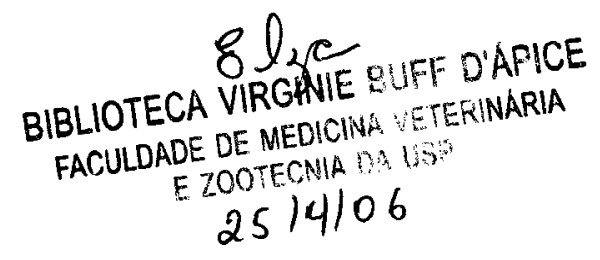

DADOS INTERNACIONAIS DE CATALOGAÇÃO-NA-PUBLICAÇÃO

(Biblioteca Virginie Buff D'Ápice da Faculdade de Medicina Veterinária e Zootecnia da Universidade de São Paulo)

\footnotetext{
T.1677 Hayashi, Ayne Murata

FMVZ Estudo clínico da eficácia da acupuntura no tratamento da discopatia intervertebral toráco-lombar em cães / Ayne Murata Hayashi.-- São Paulo : A. M. Hayashi, 2006.

$105 \mathrm{f}$ : : il.

Dissertação (mestrado) - Universidade de São Paulo. Faculdade de Medicina Veterinária e Zootecnia. Departamento de Cirurgia, 2006.

Programa de Pós-graduação: Clinica Cirúrgica Veterinária. Área de concentração: Clínica Cirúrgica Veterinária.

Orientador: Profa. Dra. Júlia Maria Matera.

1. Acupuntura. 2. Discopatia intervertebral. 3. Cães 4. Reabilitação. 5. Medicina tradicional chinesa. I. Título.
} 


\section{UNIVERSIDADE DE SÃO PAULO \\ Faculdade de Medicina Veterinária e Zootecnia}

Cidade Universitária "Armando de Salles Oliveira"

\section{Comissão de Bioética}

\section{CERTIFICADO}

Certificamos que o Projeto intitulado "Avaliação dos efeitos da acupuntura (estimulação sensorial) em cães com discopatia toraco-lombar", protocolo n636/2005, utilizando 40 cães, sob a responsabilidade da Prof ${ }^{\mathrm{a}} \mathrm{Dr}^{\mathrm{a}}$ Júlia Maria Matera, está de acordo com os princípios éticos de experimentação animal da Comissão de Bioética da Faculdade de Medicina Veterinária e Zootecnia da Universidade de São Paulo e foi aprovado "ad referendun".

(We certify that the Research "Valuation of the effects of acupuncture (sensory stimulation) in dogs with thoracolumbar disk disease", protocol number 636/2005, utilizing 40 dogs, under the responsibility of Profa Draúlia Maria Matera, agree with Ethical Principles in Animal Research adopted by Bioethic Commission of the Faculty of Veterinary Medicine and Zootechny of University of São Paulo and was approved "ad referendun", meeting).

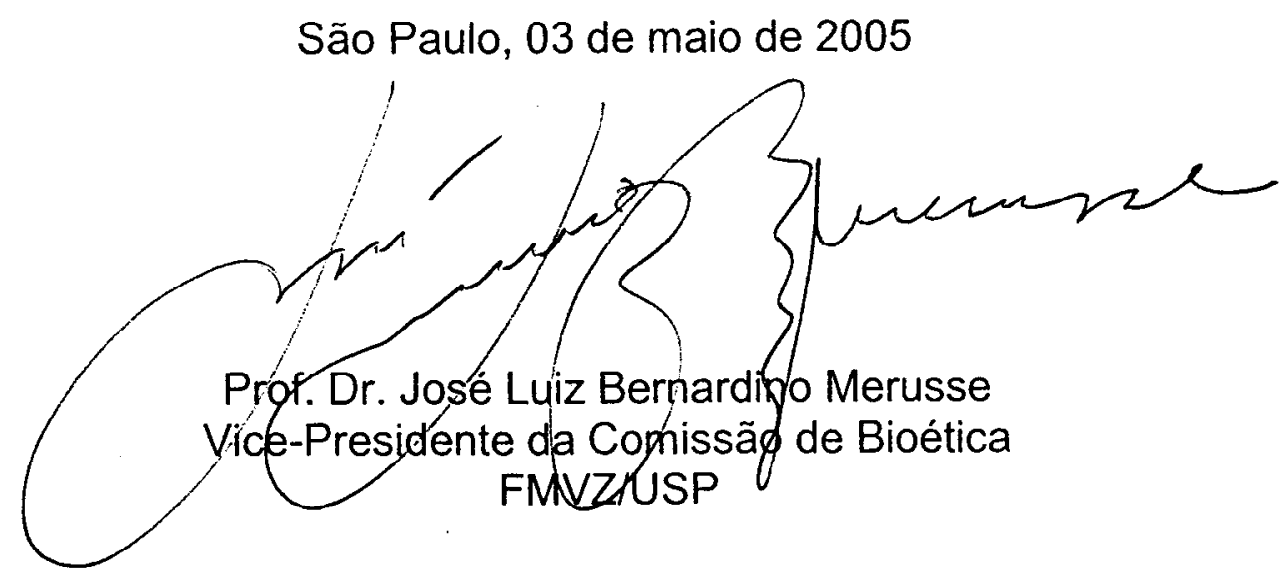




\section{FOLHA DE AVALIAÇÃO}

Nome: HAYASHI, Ayne Murata

Título: Estudo clínico da eficácia da acupuntura no tratamento da discopatia intervertebral tóraco-lombar em cães

Dissertação apresentada ao Programa de Pósgraduação em Clínica Cirúrgica Veterinária da Faculdade de Medicina e Zootecnia da Universidade de São Paulo para obtenção do título de Mestre em Medicina Veterinária

Data:

Banca Examinadora

Prof. Dr.

Assinatura:

Instituição:

Julgamento:

Prof. Dr.

Instituição:

Assinatura:

Julgamento:

Prof. Dr.

Instituição:

Assinatura:

Julgamento: 


\section{方無古令要期乎治 理無中西影求其㝠 噼建余題泗圈}

"It matters not whether medicine is old or new, so long as it brings about a cure. It matters not whether theories are eastern or western, so long as they prove to be true." Jen-Hsou Lin 


\section{DEDICATÓRIA}

Ao meu filho Renan e meu marido Wagner, devo esta conquista a vocês, pelo apoio, paciência e compreensão, pelos meus períodos de ausência, mas que sempre levei-os no meu coração!

A minha orientadora, Prof ${ }^{\text {a }}$ Júlia Maria Matera por ter confiado em meu trabalho e ter aberto esta grande oportunidade mesmo após se passarem muitos anos. Seus Ensinamentos, sua Dedicação, e seus Conselhos foram e serão sempre muito importantes para mim!

Obrigada por tudo! 


\section{AGRADECIMENTOS}

A minha mãe Edona, pelo suporte psicológico e administrativo em casa, sem você não conseguiria "cuidar" de tudo! Aos meus familiares que deram apoio e compreensão.

À Coordenação de Aperfeiçoamento de Pessoal de Nível Superior (CAPES) pelo financiamento da bolsa durante a realização deste projeto.

Ao Professor Paulo Sérgio de Morais Barros pelos sábios conselhos e apoio.

À Angélica Cecília Tatarunas pelas palavras amigas e conselhos nas horas difíceis.

À Professora Ana Carolina Fonseca Pinto pela paciência e ensinamentos das tomografias computadorizadas.

Ao Professor Stelio Pacca Loureiro Luna da FMVZ/UNESP - Botucatu, por esclarecer as dúvidas e pelos conselhos, sempre gentil e solícito.

Aos professores Ângelo João Stopiglia, Cássio Ricardo Auada Ferrigno, Denise Tabachi Fantoni, Marco Antonio Gioso, Sílvia Renata Gaido Cortopassi, Aline Ambrósio pela convivência e aprendizado.

A todos os professores da FMVZ/USP que retornei a conviver após longa data.

A todos os meus "Mestres" da MTC, amigos e colegas praticantes da acupuntura.

A todos os amigos e companheiros de pós-graduação e "futuros" colegas da pósgraduação, cujo apoio, convivência, aprendizado e incentivo ajudaram a superar as dificuldades.

Às médicas veterinárias do Serviço de Cirurgia de Pequenos Animais, FMVZ/USP, Andressa Gianotti Campos, Patrícia Ferreira de Castro, Sandra Rosner, Tatiana Soares e Viviane Sanchez Galeazzi pelo companheirismo, apoio e aprendizado. Obrigada pela ajuda neste estudo clínico!

A todos os veterinários (as) e residentes do HOVET, pelo auxílio no projeto.

Aos queridos e prestativos enfermeiros Cledson Lélis dos Santos, Jesus dos Anjos Vieira, Otávio Rodrigues dos Santos, Maurício Pavão de Oliveira, José Miron Oliveira da Silva. A todos os funcionários do HOVET pela ajuda e convivência. À Neuzinha pela alegre convivência.

A todos os amigos e colegas veterinários que incentivam e confiam no meu trabalho.

Ao secretário da pós-graduação, Belarmino Ney Pereira, pelo esforço e apoio para solucionar nossos problemas burocráticos.

Aos funcionários da biblioteca da FMVZ/USP pela ajuda na execução deste trabalho.

Aos funcionários da secretaria de pós-graduação pelo auxílio e atenção prestados. 


\section{RESUMO}

HAYASHI, A. M. Estudo clínico da eficácia da acupuntura no tratamento da discopatia intervertebral tóraco-lombar em cães. [Clinical study of the effectiveness of acupuncture in the treatment of thoracolumbar intervertebral disk disease in dogs]. 2006. $105 \mathrm{f}$. Dissertação (Mestrado em Medicina Veterinária) - Faculdade de Medicina Veterinária e Zootecnia, Universidade de São Paulo, São Paulo, 2006.

Acupuntura tem sido integrada no tratamento da discopatia intervertebral tóraco-lombar em cães com intuito de analgesia e reabilitação motora e sensorial. Faltam estudos clínicos controlados comparando acupuntura associada ao tratamento médico não cirúrgico. Foram avaliados 61 cães portadores de afecção degenerativa do disco intervertebral tóraco-lombar durante o período de março de 2005 a fevereiro de 2006. Destes 61 animais, 50 foram incluídos no estudo, 26 cães no grupo com acupuntura e 24 cães no grupo sem acupuntura. As avaliações da melhora do estado neurológico foram realizadas através de uma escala funcional numérica em 4 momentos: primeira avaliação, $7^{\circ}$ dia de avaliação, $14^{\circ}$ dia de avaliação e último retorno. Para análise estatística, nível de significância de 5\%, utilizou-se o Teste de Mann Whitney para amostras independentes e o Teste de Friedman para amostras dependentes, seguido do Teste de Wilcoxon para comparações das amostras dentro do mesmo grupo. Os valores das medianas do escore total na $1^{\mathrm{a}}$ avaliação permitiu comparação entre graus de lesão (1 a 5) subdivididos em graus 1-2 (Md 21 e 20); graus 3-4 (Md 11 e 9) e grau 5 (Md 2). O tempo de retorno a locomoção de animais sem capacidade de locomoção e presença de dor profunda (graus 3-4) foi comparado entre os grupos com $(n=10)$ e sem acupuntura $(n=6)$ através do Teste T-Student, sendo os cães que receberam acupuntura

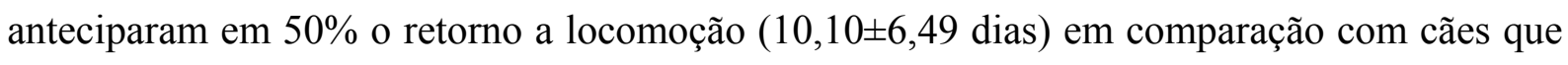
não receberam acupuntura $(20,83 \pm 11,99$ dias $)$ com diferença significativa $(p<0,034)$. Apresentaram médias superiores e com diferença significativa no escore total da escala funcional numérica na $7^{\mathrm{a}}$ e $14^{\mathrm{a}}$ avaliações $(\mathrm{p}<0,039$ e $\mathrm{p}<0,020)$ em relação ao grupo que não recebeu acupuntura, representando um estado neurológico superior. A taxa de sucesso em cães com graus 3-4 no retorno a locomoção foi de $100 \%$ e $66 \%$, respectivamente grupo com acupuntura e sem acupuntura, sendo a diferença significativa $(\mathrm{p}<0,047)$. Os cães de graus $1-2$ não apresentaram diferença significativa, sendo a taxa de sucesso em ambos os grupos de 100\%. Os cães de grau 5 tiveram taxa de sucesso no retorno a locomoção de $50 \%$ e 12,5\%, respectivamente grupo com acupuntura e sem acupuntura, não apresentando diferença 
significativa $(\mathrm{p}>0,124)$. Conclui-se que acupuntura pode ser aplicada associada ao tratamento médico em cães com discopatia tóraco-lombar, antecipando o retorno à locomoção e a melhora na evolução neurológica em cães apresentando percepção à dor profunda intacta e sem capacidade de locomoção.

Palavras-chave: Acupuntura. Discopatia intervertebral. Reabilitação. Cães. Medicina tradicional chinesa. 


\begin{abstract}
HAYASHI, A. M. Clinical study of the effectiveness of acupuncture in the treatment of thoracolumbar intervertebral disk disease in dogs. [Estudo clínico da eficácia da acupuntura no tratamento da discopatia intervertebral tóraco-lombar em cães]. 2006. $105 \mathrm{f}$. Dissertação (Mestrado em Medicina Veterinária) - Faculdade de Medicina Veterinária e Zootecnia, Universidade de São Paulo, São Paulo, 2006.
\end{abstract}

Acupuncture has been combined in the treatment of thoracolumbar disk disease in dogs with the purpose of analgesia, motor and sensorial rehabilitation. There is a lack of clinical controlled studies comparing acupuncture integrated with medical and non surgical treatment. 61 dogs with thoracolumbar disk disease were evaluated from March 2005 to February 2006. Among these 61 animals, 50 were included in the study: 26 dogs in the group with acupuncture and $24 \mathrm{dogs}$ in the group without acupuncture. The evaluations of the neurological improvement were done through a numerical functional scale in 4 moments: first, seventh, fourteenth evaluations and the last visit. For the statistical analysis, significant level of 5\%, Mann Whitney test for independent variables, Friedman test for dependent variables comparisons, followed by Wilcoxon test for dependent variables in the same group, were utilized. The median values of the total scores in the first visit permitted comparisons within lesion levels (1 to 5) divided in levels 1-2 (Md 21 and 20); levels 3-4 (Md 11 and 9) and level 5 (Md 2). The time of return of ambulation in dogs without ambulation and intact deep pain perception (levels 3-4) were compared with acupuncture group $(n=10)$ and without acupuncture group $(n=6)$ through Student $T$ test, where dogs that received acupuncture anticipated in $50 \%$ the locomotion return $(10,10 \pm 6,49$ days $)$ in comparison of dogs that didn't received acupuncture $(20,83 \pm 11,99$ days $)$ with significant difference $(p<0,034)$. These dogs showed superior means and significant difference in the total score from the numerical functional scale in the seventh and fourteeth visits $(p<0,039$ and $p<0,020)$ in relation to the group that didn't received acupuncture, showing superior neurological state. The success rate of dogs with levels 3-4 in the return of ambulation were $100 \%$ and $66 \%$, respectively acupuncture group and without acupuncture, with significant difference $(\mathrm{p}<0,047)$. The dogs with levels 1-2 didn't show difference, so that the success rate in both groups were $100 \%$. The dogs with level 5 had success rate in the return of ambulation of $50 \%$ and $12,5 \%$, respectively acupuncture group $(n=6)$ and without acupuncture $(n=8)$, but without significant difference $(\mathrm{p}>0,124)$. It was concluded that acupuncture can be applied to the medical treatment in dogs with thoracolumbar disk disease, with anticipation of the return of ambulation and the 
improvement of neurological state in animals showing intact deep pain perception and without ambulation.

Key words: Acupuncture. Intervertebral disk disease. Rehabilitation. Dogs. Chinese traditional medicine. 


\section{LISTA DE FIGURAS}

Figura 1 - Cão $\mathrm{n}^{\mathrm{o}} 14 \mathrm{em}$ decúbito lateral esquerdo recebendo tratamento com eletroacupuntura percutânea nos acupontos E36 e R3/B60 nos membros pélvicos e acupuntura clássica no acuponto ID3 nos membros torácicos FMVZ/USP - São Paulo, 2006

Figura 2 - Aparelho de eletroestimulação - FMVZ/USP - São Paulo, 2006 64

Figura 3 - Agulhas de acupuntura de diferentes tamanhos e bastão da erva Artemísia vulgaris - FMVZ/USP - São Paulo, 2006

Figura 4 - Localização dos acupontos utilizados no presente estudo - FMVZ/USP São Paulo, 2006.

Figura 5 - Cão $\mathrm{n}^{\mathrm{o}} 22$ com aspecto de sonolência durante sessão de acupuntura FMVZ/USP - São Paulo, 2006

Figura 6 - Medianas do escore funcional no momento 0 da escala funcional numérica em relação aos graus de lesão tóraco-lombar dos 62 casos analisados FMVZ/USP- São Paulo, 2006. 


\section{LISTA DE TABELAS}

Tabela 1 - Porcentagem das raças de cães - FMVZ/USP - São Paulo, 2006.

Tabela 2 - Porcentagem da localização radiográfica da extrusão do disco intervertebral - FMVZ/USP - São Paulo, 2006.

Tabela 3 - Porcentagem da localização das lesões múltiplas radiográficas FMVZ/USP - São Paulo, 2006

Tabela 4 - Porcentagem dos graus de lesão tóraco-lombar dos 62 animais do estudo FMVZ/USP - São Paulo, 2006...

Tabela 5 - Dados demográficos em relação aos tratamentos com e sem acupuntura FMVZ/USP - São Paulo, 2006

Tabela 6 - Tempo de evolução clínica em relação aos graus de lesão tóraco-lombar FMVZ/USP - São Paulo, 2006......

Tabela 7 - Tempo médio de retorno à locomoção e evolução clínica do grupo grau 3 e 4 - FMVZ/USP - São Paulo, 2006.

Tabela 8 - Média do escore funcional nos diferentes momentos em relação aos grupos tratamento com e sem acupuntura - FMVZ/USP - São Paulo. 2006

Tabela 9 - Comparação pareada dos momentos e valores de $\mathrm{p}$ em relação aos grupos com e sem acupuntura - FMVZ/USP - São Paulo, 2006

Tabela 10 - Média do escore funcional nos diferentes momentos em cães com grau $1 \mathrm{e}$ 2 em relação aos grupos tratamento com e sem acupuntura - FMVZ/USP

- São Paulo, 2006.

Tabela 11 - Comparação pareada dos momentos e valores de p em relação aos cães com graus 1 e 2 nos grupos com sem acupuntura - FMVZ/USP - São Paulo, 2006.....

Tabela 12 - Média do escore funcional nos diferentes momentos em cães com grau $3 \mathrm{e}$ 4 em relação aos grupos tratamento com acupuntura e sem acupuntura FMVZ/USP - São Paulo, 2006

Tabela 13 - Comparação pareada dos momentos e valores de p em relação aos cães com graus 1 e 2 nos grupos com e sem acupuntura - FMVZ/USP - São Paulo, 2006. 
Tabela 14 - Média do escore funcional nos diferentes momentos em cães com grau 5 em relação aos grupos tratamento com e sem acupuntura - FMVZ/USP São Paulo, 2006

Tabela 15 - Comparação pareada dos momentos e valores de $\mathrm{p}$ em relação aos cães com grau 5 nos grupos com e sem acupuntura - FMVZ/USP - São Paulo, 2006

Tabela 16 - Taxa de sucesso de tratamentos com e sem acupuntura nos diferentes graus de lesão tóraco-lombar - FMVZ/USP - São Paulo, 2006

Tabela 17 - Níveis de recuperação da micção, propriocepção e locomoção dos 50 animais do estudo - FMVZ/USP - São Paulo, 2006

Tabela 18 - Número de sessões para retorno da propriocepção, locomoção e total de sessões nos 26 cães do tratamento com acupuntura - FMVZ/USP - São Paulo, 2006 


\section{LISTA DE ABREVIATURAS E SIGLAS}

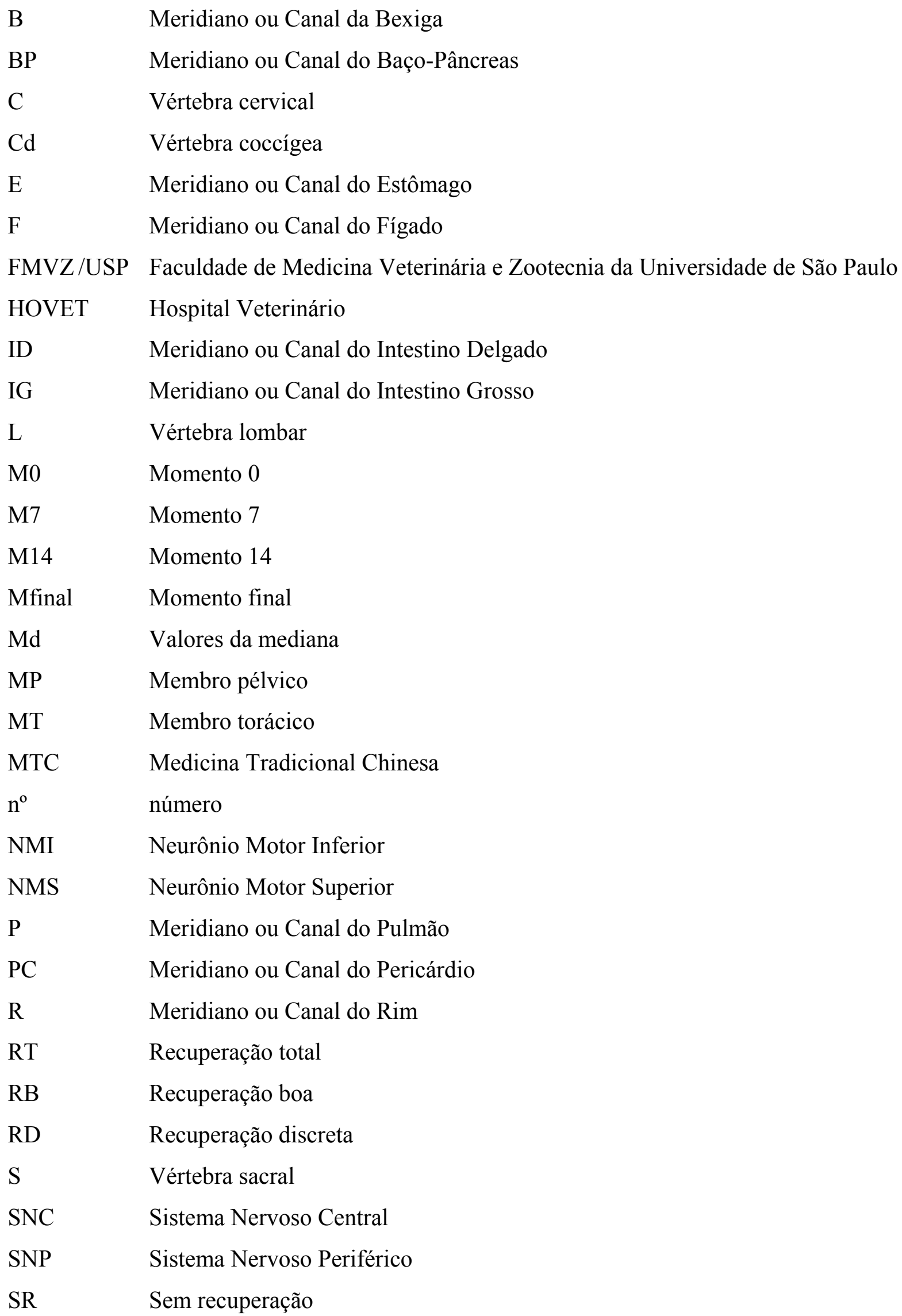


TA Meridiano ou Canal do Triplo Aquecedor

VB Meridiano ou Canal da Vesícula Biliar

VG Meridiano ou Canal do Vaso Governador 


\section{LISTA DE SÍMBOLOS}

$\begin{array}{ll}\text { W } & \text { watts } \\ \mu \mathrm{V} & \text { micro volts } \\ \mathrm{Hz} & \text { hertz } \\ \beta & \text { beta } \\ \% & \text { porcentagem } \\ \mathrm{p} & \text { valor da estatística } \mathrm{p} \text { ou } \mathrm{p} \text {-valor } \\ = & \text { igual } \\ > & \text { maior } \\ < & \text { menor }\end{array}$




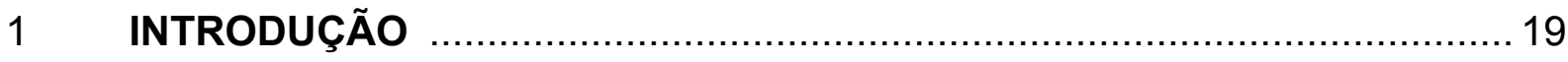

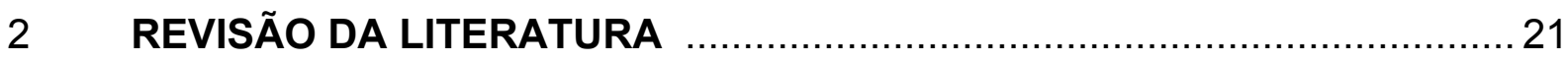

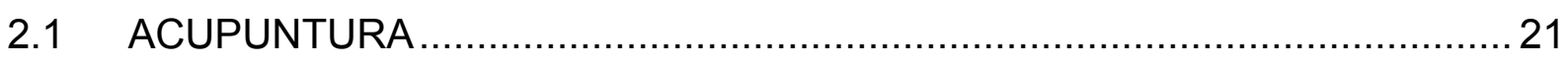

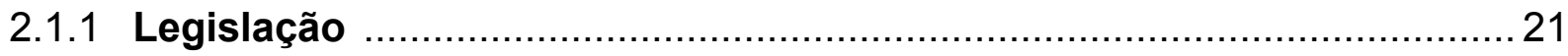

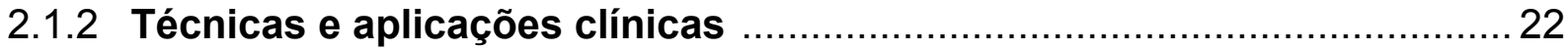

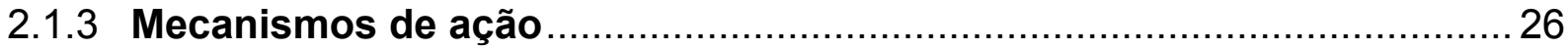

2.2 AFECÇÃO DEGENERATIVA DO DISCO INTERVERTEBRAL ................... 30

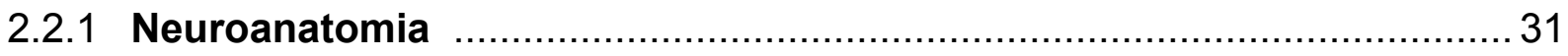

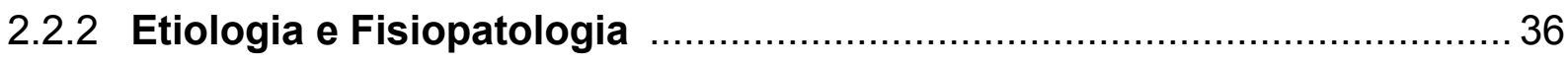

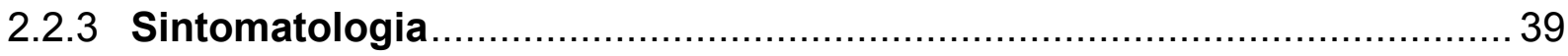

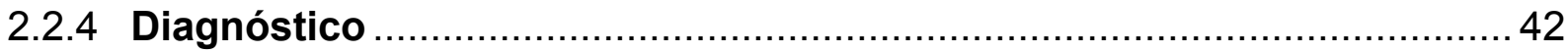

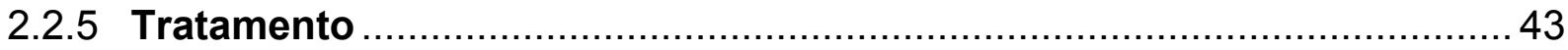

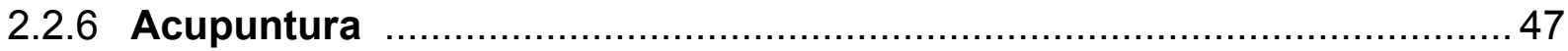

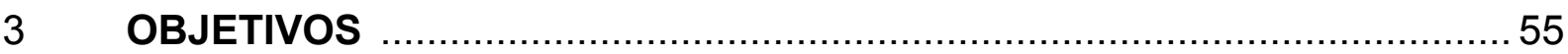

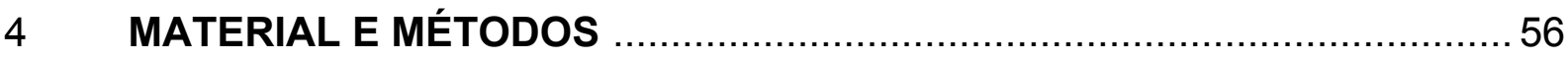

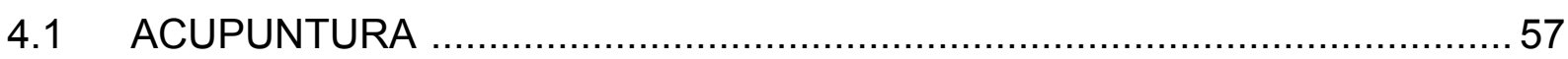

4.2 AVALIAÇÕES DOS PARÂMETROS DE EVOLUÇÃO CLÍNICA DOS

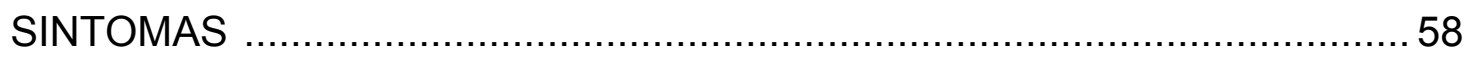

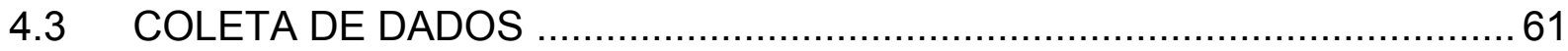

4.4 MOMENTOS DE AVALIAÇÃO PARA ANÁLISE DOS TRATAMENTOS COM ACUPUNTURA E SEM ACUPUNTURA .................................... 61

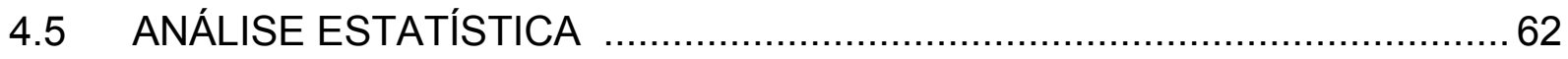

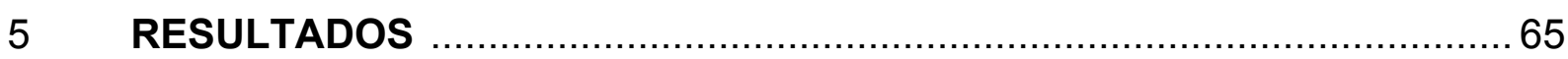

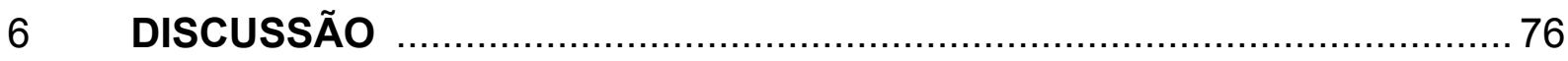

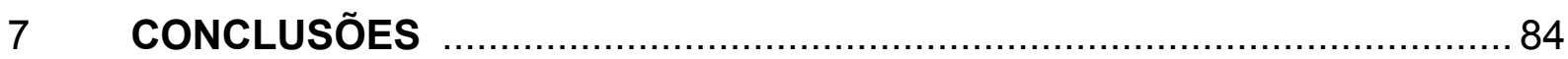

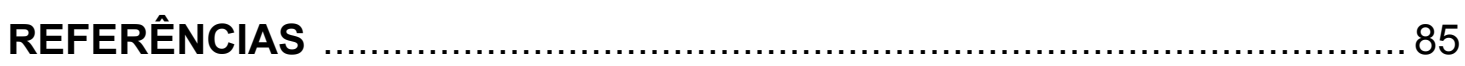

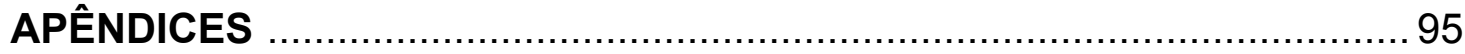




\section{INTRODUÇÃO}

A doença do disco intervertebral tóraco-lombar representa uma das afecções músculoesqueléticas degenerativas mais comuns na medicina veterinária (MCDONNELL; SIMON; CLAYTON, 2001; OLBY; DYCE; HOULTON, 1994).

A doença do disco intervertebral leva, com freqüência, a alterações neurológicas e estados dolorosos. É responsável por aproximadamente $2 \%$ das doenças diagnosticadas em cães (BRAY; BURBIDGE, 1998; COATES, 2000; OLBY et al., 2001). As raças condrodistróficas são as mais susceptíveis (COATES, 2000; NECAS, 1999; OLBY; DYCE; HOULTON, 1994). Ocorre nestas raças um processo de envelhecimento precoce dos discos intervertebrais (BRAUND, 1986), sendo relacionado a metaplasia condróide do núcleo pulposo que ocorre dentro dos primeiros anos de vida. É caracterizada pela substituição do núcleo pulposo por cartilagem hialina, seguida da mineralização (NECAS, 1999).

A incidência de afecção do disco na região tóraco-lombar tem sido demonstrada em cerca de 84 a 86\% dos casos de discopatias em cães, sendo a lesão nas raças condrodistróficas conhecida como hérnia de Hansen tipo I, representada pela extrusão do núcleo pulposo para dentro do canal medular (NECAS, 1999). Existe ainda a hérnia de Hansen tipo II que se caracteriza por uma protusão do anel fibroso, lesão esta mais comumente encontrada em cães idosos não condrodistróficos e de caráter crônico ou assintomático (COATES, 2000; JERRAM; DEWEY, 1999a).

Os sinais clínicos variam desde uma hiperestesia a paraplegia com ou sem percepção da dor profunda, incontinência urinária, chegando a mielomalácea (COATES, 2000; JANSSENS, 1992; PADILHA FILHO; SELMI, 1999).

Em relação à abordagem terapêutica, há o tratamento médico e cirúrgico, sendo citados acupuntura, repouso, antiinflamatórios e técnicas cirúrgicas descompressivas como a laminectomia e hemilaminectomia, associadas ou não a fenestração dos discos (JANSSENS, 1983, 1985, 1992; NECAS, 1999; OLBY; DYCE; HOULTON, 1994; PADILHA FILHO; SELMI, 1999; STILL, 1989).

A acupuntura pode ser utilizada em afecções do disco intervertebral tóraco-lombar com o intuito de controlar a dor, normalizar a função motora e sensorial e alterações na micção (STILL, 1989). A melhora pode ser observada a partir de uma semana até seis meses, na dependência do grau da lesão neurológica (JANSSENS, 1992). Pode atuar também 
acelerando a cicatrização tecidual e ter efeito antiinflamatório (ROGERS; SCHOEN, 1992) e na reabilitação em casos de paraplegia e espasticidade (GADULA, 1999).

Acupuntura é um método terapêutico milenar da Medicina Tradicional Chinesa (MTC). Consiste na estimulação sensorial periférica, provocando liberação de neuropeptídeos locais e a distância, devido envolvimento do Sistema Nervoso Central e Periférico (DAWIDSON et al., 1999). É grande a aceitação de seu uso médico (CARNEIRO, 2001) e também no campo da medicina veterinária (DRAEHMPAEHL; ZOHMANN, 1994; KLIDE; KUNG, 1977; LÓPEZ; BUENDIA, 1990; SCHOEN, 1994).

A partir de 1970, os efeitos e mecanismos de ação da acupuntura passaram a ser estudados cientificamente (YAMAMURA, 2002). Entretanto, sua difusão vem ocorrendo particularmente a partir de 1990, possibilitando o seu uso na medicina (CARNEIRO, 2001).

$\mathrm{O}$ fato da acupuntura proporcionar analgesia foi bem estudado por diversos autores (CASSU, 2002; JEN-CHUEN HSIEH et al., 2001; JI-SHENG HAN, 2004; LIANFANG HE, 1987; PULLAN et al., 1983), mas outros resultados clínicos de sua aplicação não são amplamente divulgados, sendo o seu uso ainda limitado (CARNEIRO, 2001).

As pesquisas elucidam alguns dos mecanismos de ação da acupuntura, porém nem todos os seus efeitos e vias de ação são explicados (LANGEVIN et al., 2001; MAYER, 2000), sendo necessários mais estudos experimentais e clínicos (YAMAMURA, 2002).

Os métodos de estudos clínicos utilizando grupos de animais tratados e controle, tornam-se importantes para avaliar a sua eficácia (CARNEIRO, 2001).

Muitos animais portadores de afecções do disco intervertebral conseguem a recuperação tanto com o tratamento cirúrgico como o não cirúrgico, independente da gravidade da lesão (SHARP; WHEELER, 2005). A acupuntura vem sendo indicada como parte integrante deste tratamento não cirúrgico. A maior dificuldade é avaliar se a melhora foi devida à acupuntura ou pela evolução natural da doença (JOSEPH, 1992). 


\section{REVISÃO DA LITERATURA}

A revisão da literatura consultada encontra-se dividida em acupuntura e afecção degenerativa do disco intervertebral.

\subsection{ACUPUNTURA}

Estima-se que a acupuntura veterinária é tão antiga quanto a história da acupuntura humana. Foi descoberto um tratado, cuja idade foi aproximada em 3000 anos, relatando o uso em elefantes indianos. O povo chinês foi o responsável pelo desenvolvimento dos conhecimentos teórico-empiricos da MTC, divulgados no documento, Huang Ti Nei Ching, ou "Clássicos do Imperador Amarelo sobre Medicina Interna" (ALTMAN, 1992, 1997).

\subsubsection{Legislação}

Na China, a acupuntura veterinária foi reavivada em 1956 com a organização de uma conferência nacional de medicina veterinária em Beijing. No Ocidente a Associação de Médicos Veterinários da Califórnia investigou a função que deve desempenhar a acupuntura veterinária. Em 1973 foi fundada a Associação Nacional de Acupuntura Veterinária (NAVA) e posteriormente, em 1974, a Sociedade Internacional de Acupuntura Veterinária (IVAS). Em seguida vários cursos de acupuntura veterinária foram realizados, o primeiro no México e depois em outros países. Em maio de 1986 foi organizado o Primeiro Simpósio Internacional de Acupuntura Veterinária em Beijing (LÓPEZ; BUENDIA, 1990).

A acupuntura na clínica veterinária moderna tem sido integrada com o intuito de buscar meios complementares de auxiliar seus pacientes. Devido à existência cada vez maior de clientes informados sobre as técnicas médicas disponíveis para o tratamento em seres humanos, aumentam as expectativas quanto às possibilidades de tratamento de seus animais de estimação (ALTMAN, 1992). 
A conscientização sobre esta técnica terapêutica vem aumentar a investigação científica acerca de seus mecanismos de ação e aplicações clínicas. Em 1988 a Associação Médica Veterinária Americana declarou, nas Diretrizes da Acupuntura, que a Acupuntura Veterinária e Aquapuntura fazem parte da Medicina Veterinária como um procedimento médico e/ou cirúrgico (SCHOEN, 1994).

No Brasil, foi fundada, em 1999, a Associação Brasileira de Acupuntura Veterinária (LUNA, 2002) e segundo a Resolução número 756, de 17 de outubro de 2003, várias normas foram apresentadas para o registro de Título de Especialistas em áreas da Medicina Veterinária, sendo a acupuntura veterinária, a exemplo na medicina humana, é considerada uma das especialidades publicadas em Anexo a esta Resolução (ARRUDA; CARVALHO, 2003).

\subsubsection{Técnicas e aplicações clínicas}

A acupuntura corresponde a uma das técnicas de tratamento da MTC. Consiste na inserção de agulhas e/ou transferência de calor em áreas definidas da pele e tecidos subjacentes, denominados acupontos. Restabelece o equilíbrio de estados funcionais alterados, atingindo a homeostase, através da influência sobre determinados processos fisiológicos (DRAEHMPAEHL; ZOHMANN, 1994; YAMAMURA, 2001).

A MTC baseia-se no equilíbrio ou harmonia tanto no interior do organismo como o relacionamento com o meio exterior. Inclui a homeostasia das funções neuroendócrinas, estado emocional, influência hereditária. Considera também um equilíbrio entre o corpo e o meio ambiente externo. O conceito básico utilizado é representado pelos termos Yin e Yang, ou seja, energias opostas e ao mesmo tempo complementares. Pode-se interpretar estas metáforas resumidamente como os processos de anabolismo (Yin) e catabolismo (Yang), ou ainda influência parassimpática e simpática (JAGGAR, 1992).

A acupuntura é derivada do latim acus e pungere, respectivamente agulha e puncionar, mas atualmente outros meios de estímulo dos acupontos são utilizados (ALTMAN, 1997). A expressão chinesa Zhen Jiu, espetar e queimar, traduz de forma mais completa o método, que utiliza comumente o calor como fonte de estímulo (DRAEHMPAEHL; ZOHMANN, 1994).

Acupuntura é uma terapia reflexa, em que o estímulo de uma região age sobre outras. Para esta finalidade, utiliza principalmente o estímulo nociceptivo, que são receptores 
específicos para a dor e terminações nervosas livres de fibras aferentes A delta e C. Ocorre transformação do estímulo mecânico, térmico ou químico em impulso nervoso (CASSU, 2002; SCOGNAMILLO-SZABÓ; BECHARA, 2002).

Portanto, a acupuntura consiste na estimulação sensorial ou estímulo neural periférico, provocando liberação de neuropeptídeos locais e a distância, devido envolvimento do Sistema Nervoso Central e Periférico (DAWIDSON, 1999).

Tradicionalmente é descrito um sistema de Meridianos ou Canais que conduzem energia, ou seja, $Q i$, pelo organismo. São constituídos basicamente de 12 pares de Meridianos Principais ou Regulares e 2 pares de Meridianos, Vaso Governador e Vaso Concepção, respectivamente nas linhas média dorsal e ventral. Em cada membro locomotor podemos encontrar 3 Meridianos Principais na face dorsal ou cranial e 3 na face ventral ou caudal, que se relacionam entre si e são integrados aos órgãos internos. Recebem a nomenclatura de: Pulmão, Intestino Grosso, Estômago, Baço-Pâncreas, Coração, Intestino Delgado, Bexiga, Rim, Pericárdio, Triplo Aquecedor, Vesícula Biliar e Fígado (CASSU, 2002; LI DING, 1996). Nos Estados Unidos e na Europa, ao invés dos nomes chineses tradicionais dos acupontos, são identificados por um código alfanumérico, demonstrando o Meridiano onde se localiza e o seu número sobre o mesmo (SCOGNAMILLO-SZABÓ, 1999).

A necessidade de uma linguagem única para troca de informações mundialmente levou a Organização Mundial da Saúde (OMS) a estabelecer uma nomenclatura internacional padrão (STANDARD, 1990).

Além da técnica tradicional de estimulação manual das agulhas nos animais, outras técnicas podem ser utilizadas, serão descritas sucintamente. A laserpuntura consiste na estimulação do acuponto com aparelho de Laser de baixa potência com capacidade até $130 \mathrm{~W}$ (ALTMAN, 1992; DRAEHMPAEHL; ZOHMANN, 1994). A moxabustão indireta é realizada através do aquecimento indireto sobre o acuponto com um bastão da erva Artemísia vulgaris (ALTMAN, 1992; DRAEHMPAEHL; ZOHMANN, 1994). A acuinjeção pode ser realizada através da aplicação de pequenas quantidades de solução fisiológica ou medicamentos nos acupontos (ALTMAN, 1992; DRAEHMPAEHL; ZOHMANN, 1994; LOPEZ; BUENDIA, 1990). A digitopuntura corresponde a uma pressão ou massagem digital nos acupontos (LOPEZ; BUENDIA, 1990). A eletroacupuntura percutânea consiste na aplicação de uma corrente elétrica que é conduzida através das agulhas inseridas, estimulando os acupontos (ALTMAN, 1992; DRAEHMPAEHL; ZOHMANN, 1994; LOPEZ; BUENDIA, 1990). 
A eletroacupuntura é agora amplamente usada na China, principalmente em estudos científicos relacionados a analgesia (LIANFANG HE, 1987), pois é mais fácil de ser controlada e desenvolver protocolos de tratamento. Ela não deve ser usada para todas as patologias, devendo ser evitada em pacientes gestantes, hipertensos e cardíacos (KIRSCH; LERNER, 2004; KLIDE; KUNG, 1977; LÓPEZ; BUENDIA, 1990).

Os animais devem ser posicionados adequadamente, em decúbito lateral ou em estação (LOONEY, 2000) e contidos com ajuda do proprietário, sendo raramente usada contenção química (ALTMAN, 1992). Procede-se a inserção das agulhas ou escolha de outro método de estímulo, sendo a duração do evento entre 20 a 30 minutos (ALTMAN, 1992).

Acupuntura pode ser aplicada a cada 2 ou 3 dias em casos agudos (ALTMAN, 1997) e em casos crônicos uma vez por semana durante 4 a 8 semanas. Quando o quadro se estabiliza, pode-se diminuir a freqüência a intervalos quinzenais e posteriormente avaliar a cada 3 a 6 meses, sendo aconselhado em períodos de estação mais quente ou fria do ano, de acordo com o diagnóstico baseado na MTC (SCHOEN, 1994).

Devido a sua abordagem diferente na saúde e na doença, é usada integrando outros tratamentos para muitas patologias (LOONEY, 2000).

Diversas publicações relatam as possibilidades de aplicações clínicas da acupuntura veterinária. Recomenda-se a sua indicação nas patologias neurológicas e músculoesqueléticas como paralisias e paresias por patologias de disco intervertebral (ANGELI et al., 2003; DRAEHMPAEHL; ZOHMANN, 1994; HAYASHI et al., 2005; HAYASHI; SHIGUIHARA; TORRO, 2003; JANSSENS, 1983, 1985, 1992; JOAQUIM et al., 2003) e espondilopatias, síndrome da cauda eqüina, paralisias faciais, epilepsias (ALTMAN, 1992; DRAEHMPAEHL; ZOHMANN, 1994; JOAQUIM et al., 2003; JOSEPH, 1992), osteoartrose (JANSSENS, 1986). Há relatos de benefícios em afecções reprodutivas (DRAEHMPAEHL; ZOHMANN, 1994; JEN-HSOU LIN; PANZER, 1992; ROGERS; SHOEN; LIMEHOUSE, 1992) e gastrointestinais (DRAEHMPAEHL; ZOHMANN, 1994; ROGERS; SHOEN; LIMEHOUSE, 1992); em alterações do sistema urinário como nefrites, cistites, uretrites, urolitíases e distúrbios na micção e diurese (DRAEHMPAEHL; ZOHMANN, 1994; ROGERS; SHOEN; LIMEHOUSE, 1992).

Outras aplicações incluem a reabilitação em sequelas de infecção viral como a cinomose (COLE, 1996; HAYASHI; CARRERA, 2004; JOAQUIM et al., 2003; ROGERS; SHOEN; LIMEHOUSE, 1992); doenças imune-mediadas como alergias, imunossupressões, doenças autoimunes (ROGERS; SHOEN; LIMEHOUSE, 1992); otite (SÁNCHEZ-ARAÚJO; PUCHI, 1997); cicatrização e regeneração tecidual como em úlceras na pele (ROGERS; 
SHOEN; LIMEHOUSE, 1992); fraturas ósseas (SHARIFI; BAKHTIARI, 2003; SHEN MEIHONG, 1999); injúrias musculares e tendíneas (BAKHTIARI et al., 2003; SHARIFI et al., 2003); osteomielites (DRAEHMPAEHL; ZOHMANN, 1994) e analgesia (CASSU et al., 2003; SCHOEN, 1994).

Estudo experimental demonstrou que a eletroacupuntura aumenta a motilidade intestinal em cães, podendo ser utilizada em animais com distúrbios de constipação (LUNA; JOAQUIM $^{1}$, 1998, apud JOAQUIM, J.G.F, 2003).

Estudo ultrassonográfico permitiu a visualização gráfica da motilidade intestinal após acupuntura nos acupontos E36 e B27, promovendo respectivamente aumento e diminuição da mesma (MINCHEOL CHOI et al., 2001).

Outros dois estudos experimentais controlados em cães avaliaram o efeito da eletroacupuntura na cicatrização do músculo bíceps femoral e no tendão de Aquiles. Concluiu-se que é bastante efetiva em antecipar o processo de cicatrização da musculatura devido a um efeito estimulante a nível celular (BAKHTIARI et al., 2003) e na cicatrização tendínea devido a um aumento na velocidade de arranjo de fibras colágenas regulares (SHARIFI et al., 2003).

Acupuntura promoveu efeito estimulatório na formação de calo ósseo em relação ao grupo controle, em cães com fratura radial induzida experimentalmente e submetidos a imobilização externa (SHARIFI; BAKHTIARI, 2003). O mecanismo da acupuntura em promover consolidação óssea em fratura, foi correlacionada a um aumento nos níveis séricos de hormônios tiroideanos e tirotropina (TSH) em coelhos com fratura do rádio induzida experimentalmente (SHEN MEIHONG et al., 1999).

$\mathrm{O}$ efeito da acupuntura sobre o processo regenerativo induzido em girinos submetidos à amputação da cauda, revelou mudanças significativas na morfologia do tecido em regeneração no grupo que recebeu tratamento. Aos 44 dias de evolução no grupo que recebeu 13 estímulos, ocorreu neoformação evidente de células musculares. O estudo sugeriu interação da acupuntura com a regeneração e provável ativação da produção de neuropeptídeos com propriedades vasodilatadoras. Estes neuropeptídeos são considerados de importância fundamental para cicatrização de feridas e doenças isquêmicas (GAVIOLLE, 1999).

\footnotetext{
${ }^{1}$ LUNA, S. P. L.; JOAQUIM, J. G. F. Effect of electroacupuncture on intestinal motility in dogs. In: ANNUAL INTERNATIONAL VETERINARY ACUPUNCTURE, 24., 1998, China. Proceedings... Taiwan: The International Veterinary Acupuncture Society and The Chinese Society of Traditional Veterinary Science, 1998, p. 134-36.
} 
Estudo controlado em ratos com ovários policísticos induzidos experimentalmente, verificou mudanças no estado neuroendocrinológico nestes ovários quando submetidos a tratamentos repetidos com eletroacupuntura. Parece ter papel importante nas patologias reprodutivas (STENER-VICTORIN et al., 2001).

\subsubsection{Mecanismos de ação}

Estudos foram realizados para elucidar os mecanismos biológicos da acupuntura (MAYER, 2000) e envolvimento de peptídeos opióides endógenos na analgesia por acupuntura (HONG JIN PAI et al.,2004; JI-SHENG HAN, 2004; LIANFANG HE, 1987; PULLAN et al., 1983).

A ação da acupuntura começa com o acuponto, sendo o primeiro aspecto a ser considerado (LUNA, 2002).

O ponto de acupuntura ou acuponto é uma área cutânea que apresenta baixa resistência elétrica e grandes concentrações de terminações nervosas livres, feixe e plexos nervosos, mastócitos, linfáticos, capilares e vênulas. Os diversos pontos contém proporções variadas de tipos de terminações nervosas e diferentes relacionamentos com os nervos principais, além de estar em relação íntima com tendões, periósteos e cápsulas articulares (SCOGNAMILLOSZABÓ; BECHARA, 2001; SMITH, 1992; YANN-CHING HWANG, 1992).

Os acupontos estão tipicamente localizados entre músculos, entre um músculo e um tendão, entre um músculo e uma estrutura óssea (LANGEVIN; CHURCHILL; CIPOLA, 2001). Os acupontos da região dos membros estão situados nos meridianos que correspondem ao trajeto de nervos principais e vasos sanguíneos, os da região do tronco relacionam-se com a inervação segmentar e local de penetração de nervos e vasos sanguíneos na fáscia muscular, e os da cabeça e face estão próximos aos nervos cranianos e cervicais superiores (SCOGNAMILLO-SZABÓ; BECHARA, 2001).

Muitas vezes o uso somente da inserção de agulhas é indicado. Yamamura et al. (1996), investigaram propriedades biofísicas das agulhas de acupuntura para uma melhor compreensão dos seus efeitos elétricos, onde concluíram que as agulhas desenvolveram um potencial elétrico na ponta, isoladamente de $1800 \mu \mathrm{V}$, capaz de provocarem a despolarização da membrana da célula nervosa. Desta forma o estímulo da acupuntura é transmitido do acuponto para a medula espinal através dos nervos periféricos aferentes (SMITH, 1992). 
Como mecanismo local da acupuntura, é relatado além do efeito de relaxamento muscular (CARNEIRO, 2001; STILL, 2003), estímulo à regeneração tecidual, a promoção de uma alteração elétrica, seja pela presença da agulha ou por eletroacupuntura (CARNEIRO, 2001).

Segundo Draehmpaehl e Zohmann (1994), uma ação local desencadeada com a acupuntura, é a indução de efeitos piezoelétricos do colágeno, que funcionaria como um dipolo e se posiciona de acordo com os campos elétricos. Ocorre estímulo a movimentação do tecido conjuntivo colagênico nos tendões, ligamentos e cápsulas articulares. Ativa fibrócitos e a colagênese em tendões, cartilagem e ossos, similar ao fenômeno que ocorre quando se exerce uma pressão no colágeno, correspondendo ao estresse de compressão do osso (GUYTON, 1984).

De acordo com Langevin, Churchill e Cipola (2001), a manipulação da agulha de acupuntura provoca uma deformação do tecido conjuntivo, composto por matriz extracelular e fibras de colágeno, havendo a transmissão de sinal mecânico dentro de fibroblastos e outras células aderidas às fibras de colágeno e uma resposta celular de rearranjo no citoesqueleto, estimulando variados sensores mecanoreceptores e/ou nociceptores. Este efeito é importante, pois não se restringe ao local da agulha de acupuntura, podendo se espalhar a planos de tecido conjuntivo intersticial. Gera também alterações no fluxo sanguíneo, citocinas e/ou fatores de crescimento que resultam na modulação a longo prazo da informação sensorial e o efeito da acupuntura que pode durar horas ou dias.

Através dos conhecimentos neuroanatômicos e neurofisiológicos (YAMAMURA et al., 1997), a acupuntura médica atual pode ser definida como um método de estimulação neural periférica que acessa o SNC, objetivando um reajuste nas funções cerebrais, neurais, hormonais, imunitárias e viscerais, ou seja, originando o termo neuromodulação (CARNEIRO, 2001).

São relatados tanto efeitos sistêmicos devido a participação dos centros superiores do SNC e efeitos locais relacionados à liberação de diversas substâncias e neurotransmissores: histamina, bradicinina, prostaglandina, serotonina (DRAEHMPAEHL; ZOHMANN, 1994), substância P e peptídeo calcitonina-gene-relacionado (CGRP), $\beta$-endorfinas, encefalina e dinorfinas, noradrenalina, acetilcolina, adenosina, somatostatina, ácido gama-aminobutírico, vasopressina, angiotensina, corticotropina (ACTH), colecistoquinina, ácido glutâmico (CARNEIRO, 2001; HONG JIN PAI et al., 2004). Dois estudos demonstraram que a estimulação sensorial (acupuntura) aumentou a liberação de CGRP e do peptídeo vasoativo 
intestinal (VIP) na saliva de pacientes portadores de xerostomia, sendo que estariam relacionados ao efeito benéfico sobre o fluxo salivar (DAWIDSON et al.,1998; 1999).

As citocinas estão implicadas em condições imunes e inflamatórias. São produzidas principalmente por macrófagos e linfócitos. Algumas são inflamatórias e outras são antiinflamatórias. As interleucinas fazem parte desta grande família, sendo as interleucinas 4 (IL4) e interleucinas 10 (IL10) mediadoras da regulação das condições imunoinflamatórias. Sabe-se que as citocinas podem regular a liberação pituitária de $\beta$-endorfinas. Por outro lado outras fontes de $\beta$-endorfinas compreendem células imunológicas que podem ter influência na inflamação, sugerindo que as endorfinas não estão envolvidas somente com analgesia. Além das endorfinas, outros neuropeptídeos podem estimular linfócitos. Desta forma a acupuntura pode amplificar esta interação de neuropeptídeos e citocinas, além do seu conhecido efeito em aumentar a contagem de leucócitos no sangue periférico. Este processo fisiológico pode estar implicado com os relatos dos efeitos da acupuntura em condições imunoinflamatórias como na asma bronquial e artrite reumatóide (BONTA, 2002).

O neuropeptídeo VIP foi relacionado com o aumento da taxa de fluxo salivar por estimulação acupuntural. O estímulo sensorial através de reflexos, ativa eferentes parassimpáticos, aumentando a liberação de VIP, com propriedades anitiinflamatórias e imunoregulatórias (DAWIDSON et al., 1998). CGRP está envolvido na angiogênese (HUKKANEN et al., 1993), importante na regeneração tecidual. As fibras nervosas não estimuladas parecem não liberar em grandes quantidades este peptídeo, mas a estimulação acarreta liberação em terminações nervosas e as concentrações locais deste neuropeptídeo tornam-se significativas (KONTTINEN; IMAI; SUDA, 1996).

Pullan et al. (1983) relacionaram a liberação de hormônio de crescimento após eletroacupuntura em pacientes portadores de dores crônicas, sendo mediada através dos peptídeos opióides endógenos. Estes peptídeos estão em grandes concentrações nos neurônios hipotalâmicos, sugerindo o envolvimento destes opióides no controle de secreção de hormônios pituitários.

A participação de receptores tipo polimodais tem sido evidenciada no mecanismo periférico da acupuntura e moxabustão. Estes receptores polimodais são responsíveis a estímulos mecânicos, químicos e térmicos e consistem em terminações nervosas livres. Localizam-se em diversos tecidos, podendo estar sensibilizados e presentes nos pontosgatilho. Sabe-se que muitos pontos-gatilho correspondem a pontos de acupuntura (KAWAKITA; GOTOH, 1996). 
Diversos modelos explicam os possíveis mecanismos de ação para a analgesia acupuntural, sendo conhecido um modelo neurohumoral, onde a agulha de acupuntura estimula os aferentes A-delta de um neurônio periférico, que termina no corno dorsal da medula espinhal, transfere o impulso a um segundo neurônio dentro do mesmo segmento espinhal, ativando três níveis do sistema nervoso. Em ordem ascendente estes níveis são: medula espinhal dentro do mesmo segmento, região supra-espinhal - substância cinzenta periaquedutal, núcleo magno da rafe e o complexo hipófise-hipotálamo. Quando cada um destes níveis são estimulados, endorfinas específicas e monoaminas, serotonina e adrenalina tornam-se envolvidas em uma cascata química que inibe a dor (SMITH, 1992; YAMAMURA, 2002). Baseado nestes mecanismos, o uso conjunto do fármaco triptofano para aumentar os níveis de serotonina e D-fenilalanina e bacitracina para inibir o metabolismo de endorfinas podem aumentar a analgesia por acupuntura (SMITH, 1992).

Vários estudos indicam esta ativação de áreas cerebrais com acupuntura. Um estudo controlado randomizado com tomografia computadorizada com emissão de fóton simples evidenciou ativação do hipotálamo com eletroacupuntura a $2 \mathrm{~Hz}$ no acuponto IG4 em pacientes humanos (JEN-CHUEN HSIEH et al., 2001).

Estudo controlado experimental em humanos com ressonância magnética funcional, evidenciou ativação do córtex visual com laser acupuntura no acuponto B67, descrito classicamente para uso em desordens visuais ou dor ocular, o mesmo não ocorrendo com o grupo placebo. Demonstrou-se que a laserpuntura pode induzir resposta específica na região do córtex cerebral (SIEDENTOPF et al., 2002).

Estudo experimental em ratos evidenciou, através de ressonância magnética funcional, uma ativação precoce e proeminente em áreas cerebrais moduladoras da dor após eletroacupuntura em acupontos comumente usados em analgesia quando comparados a acupontos sem indicação analgésica (JEN-HWEY CHIU et al., 2003).

O estímulo da acupuntura afeta diferentes partes do Sistema Nervoso, tanto o motor e sensorial do SNC como o Sistema Nervoso Autonômico. Estudos demonstraram que a estimulação acupuntural exerce seu efeito aumentando a liberação de neuropeptídeos de terminações nervosas e que mimetiza os efeitos do exercício físico (DAWIDSON et al., 1999). A acupuntura ativa receptores ou fibras nervosas no tecido estimulado, da mesma forma que são ativados fisiologicamente por contrações musculares. Este fato leva a efeitos nas funções de determinados órgãos similares aos obtidos com exercícios físicos prolongados. Tanto a acupuntura como exercício físico produzem descargas rítmicas nas fibras nervosas e 
causam liberação de opióides endógenos e oxitocina (ANDERSON; LUNDEBERG², 1995, apud CARNEIRO, 2001).

Os resultados da acupuntura estão relacionados ao estímulo que é feito no acuponto, ou seja, intensidade, duração e freqüência do estímulo (YAMAMURA, 2002). As baixas freqüências liberam encefalina por todo Sistema Nervoso Central e $\beta$-endorfina no cérebro, promovendo efeito na atividade visceral. Isto é confirmado com a inibição dos seus efeitos por naloxone, um antagonista opióide específico. Freqüências mais altas liberam dinorfina na medula espinhal (CASSU et al., 2003; HONG JIN PAI et al., 2004; LIANFANG HE, 1987; YAMAMURA, 2002).

Segundo Smith (1992), as baixas freqüências, menores do que $5 \mathrm{~Hz}$, promovem a liberação de metaencefalinas na medula espinhal, com estimulação de fibras A-delta. As freqüências altas, maiores do que $100 \mathrm{~Hz}$, liberam dinorfina na medula espinhal e estimulam principalmente fibras C. As freqüências mais altas, maiores do que $200 \mathrm{~Hz}$ estimulam analgesia relacionada com serotonina e noradrenalina.

Estudo revelou com mais precisão que $2 \mathrm{~Hz}$ acelera a liberação de encefalina, $\beta$ endorfina e endomorfina, enquanto que $100 \mathrm{~Hz}$ aumenta seletivamente a liberação de dinorfina. A combinação destas duas freqüências leva a produção simultânea dos quatro peptídeos opióides e um efeito terapêutico máximo (JI SHENG HAN, 2004).

Nem todos os efeitos da acupuntura são relacionados aos opióides. Um estudo em ratos a inflamação aguda foi induzida por carragenina e após, submetidos a eletroacupuntura com $4 \mathrm{~Hz}$ nos acupontos E36 e BP6. Foi evidenciado o efeito antiinflamatório não dependente de opióide, pois não foi inibido por naloxone (SHI PING ZHANG et al., 2004). O efeito antiinflamatório da eletroacupuntura em modelo experimental em ratos com colite demonstrou ser mediada por ativação de receptores $\beta$-adrenérgicos mas não por mecanismos dependentes de glicocorticóides endógenos (JEOUNG-WOO KANG et al., 2004).

\subsection{AFECÇÃO DEGENERATIVA DO DISCO INTERVERTEBRAL}

A degeneração do disco intervertebral representa uma afecção sistêmica e músculoesquelética e pode provocar lesão da medula espinhal através da protusão ou extrusão do

\footnotetext{
${ }^{2}$ ANDERSON, S.; LUNDEBERG, T. Acupuncture - from empirism to science: functional knowledge of acupuncture effects in pain and disease. Medical Hypotheses, v. 45, n. 3, p. 271-281, 1995.
} 
núcleo pulposo para o interior do canal medular (BRAUND, 1986; COATES, 2000; JERRAM; DEWEY, 1999a). Há considerável controvérsia na literatura veterinária em relação ao diagnóstico e tratamento da discopatia intervertebral, além de uma vasta variação nas alterações neurológicas (COATES, 2000). Com o intuito de auxiliar no diagnóstico e planejamento terapêutico, é de extrema relevância a compreensão da anatomia e fisiopatologia da discopatia intervertebral (JERRAM; DEWEY, 1999a).

\subsubsection{Neuroanatomia}

O disco intervertebral é uma estrutura que conecta vértebras contíguas desde a segunda vértebra cervical (C2) ao sacro, sendo o diâmetro dos discos da região cervical maior do que os da região torácica (COATES, 2000). É composto externamente pelo anel fibroso, formado por lâminas de tecido fibrocartilaginoso, e internamente pelo núcleo pulposo, que consiste de material gelatinoso, sendo também descrito outros componentes como água, fibras de colágeno, moléculas de proteoglicanas e outras células, como fibrócitos e condrócitos (JERRAM; DEWEY, 1999a). As porções laterais e ventral do anel fibroso são mais espessas do que a dorsal (BRAY; BURBIDGE, 1998; COATES, 2000; JERRAM; DEWEY, 1999a).

As estruturas de suporte do disco intervertebral são compostas pelos ligamentos longitudinais dorsal e ventral, e limitado pelas placas cartilaginosas que recobrem as epífises dos corpos vertebrais, formando os limites cranial e caudal de cada disco (BRAY; BURBIDGE, 1998; COATES, 2000). O ligamento longitudinal ventral estende-se das superfícies ventrais dos corpos vertebrais a partir da $\mathrm{C} 2$, e o ligamento longitudinal dorsal une fortemente os corpos vertebrais, desde a região mediana do leito do canal vertebral e ao anel fibroso dorsal de cada disco. Na região cervical este ligamento longitudinal dorsal é espesso e largo e portanto, resiste a extrusão dorsal do material discal, desviando lateralmente em direção as raízes nervosas espinhais. Ocasiona freqüentemente dor radicular ao invés dos sinais de compressão medular. Por outro lado, na região tóraco-lombar e lombar, este ligamento é mais fino e permite facilmente a extrusão dorsal do material discal e compressão medular (TOOMBS, 1992). As fibras do ligamento longitudinal dorsal unem-se com as do anel fibroso do disco intervertebral, ambos carreando fibras nervosas responsáveis pela nocicepção (SHARP; WHEELER, 2005). O ligamento longitudinal dorsal é mais ricamente 
inervado do que o anel fibroso. A inervação do anel fibroso ocorre somente na periferia (JERRAM; DEWEY, 1999a).

Da segunda a décima vértebras torácicas há presença do ligamento intercapital ou conjugal, entre as cabeças das costelas opostas, encontradas ventralmente ao ligamento longitudinal dorsal e dorsalmente aos discos, sendo espesso e contribuindo pela baixa incidência de extrusão nos espaços intervertebrais da coluna torácica cranial a T10 (JERRAM; DEWEY, 1999a; SHARP; WHEELER, 2005).

O ligamento flavum é encontrado na superfície dorsal do canal vertebral e no espaço entre a lâmina vertebral adjacente, sendo contínuo com as cápsulas articulares dos processos articulares. Ele pode estar espessado de forma significativa em algumas condições patológicas, particularmente na doença lombo-sacra e espondilomielopatia cervical (SHARP; WHEELER, 2005).

Estudos indicam que o núcleo pulposo normalmente está sob um constante grau de compressão pela musculatura adjacente (BRAY; BURBIDGE, 1998). O anel fibroso de um cão normal está sujeito a um estresse de tensão maior do que ao de compressão. $\mathrm{O}$ fato de predominar fraturas vertebrais em relação a discos rompidos devido a traumas espinhais, denota a grande habilidade do disco intervertebral de resistir a estas forças (TOOMBS, 1992).

A coluna vertebral do cão é muito flexível na direção dorsal e pouco móvel na direção ventral, mas a mobilidade é maior na região tóraco-lombar, promovendo impulso propulsor para os membros pélvicos durante o galope. O disco intervertebral tem papel importante em atenuar o impacto que ocorre através da coluna vertebral durante uma corrida, além de conferir a flexibilidade nesta espécie. No cão, a lesão tóraco-lombar ocorre em $70 \%$ dos casos de extrusão de disco, entre a $12^{\mathrm{a}}$ vértebra torácica (T12) e a segunda vértebra lombar (L2). Esta tendência difere nos humanos, onde a região mais afetada é a lombo-sacra e entre L4 e L5 (BRAY; BURBIDGE, 1998).

Segundo Braund (1986), 85\% das extrusões em cães ocorrem na área tóraco-lombar e $15 \%$ nas cervicais e cerca de $80 \%$ das lesões tóraco-lombares ocorre entre T11 e L3 e menos do que $2 \%$ na região lombo-sacra, L5 a S1.

Uma particularidade anatômica da região das vértebras torácicas é observada pela mudança de direção do processo espinhoso, sendo o local desta mudança denominado de vértebra anticlinal. Os processos espinhosos das vértebras torácicas até T10 inclinam caudalmente, e das duas últimas vértebras torácicas inclinam cranialmente, podendo ocorrer variações na localização (SHARP; WHEELER, 2005). 
O disco intervertebral tem um suprimento sanguíneo pobre (SHARP; WHEELER, 2005), sendo que os nutrientes conseguem acesso por difusão através da superfície das placas cartilaginosas (JERRAM; DEWEY, 1999a), principalmente na região do núcleo pulposo, e para pequenos solutos não iônicos, a região da periferia do anel também é importante (COATES, 2000).

No caso de cátions, as placas cartilaginosas são as vias mais efetivas. Os glicosaminoglicanos (GAGS) promovem uma carga negativa e determinam a concentração de solutos iônicos. Por outro lado, o transporte de solutos maiores, como albumina, enzimas, hormônios, são proporcionados por mecanismos de bombeamento. O metabolismo do disco intervertebral é principalmente anaeróbico, mesmo com altos níveis de tensão de oxigênio. Com o decréscimo dos níveis de oxigênio, aumentam os níveis de produção de ácido lático, acarretando em baixo $\mathrm{pH}$ e ativação de enzimas degradantes de matriz extracelular. $\mathrm{O}$ exercício influencia a capacidade aeróbica do meio intradiscal, portanto cães que exercitam, aumentam o metabolismo aeróbico do anel externo e região interna do núcleo pulposo. Em casos de fusão discal há um decréscimo da atividade metabólica, devido a uma diminuição da área de contato. $\mathrm{O}$ exercício pode aumentar este contato entre o disco e suprimento sanguíneo (COATES, 2000).

O suprimento arterial à coluna vertebral é segmentado, consistindo de um ramo espinhal entrando no canal vertebral através do forame intervertebral, intimamente associado ao nervo espinhal. A origem destes ramos varia de acordo com a região da coluna, sendo que na região da coluna torácica, são provenientes das artérias intercostais, penetrando no canal vertebral através do forame intervertebral. Por sua vez, na coluna lombar, os ramos espinhais provêm das artérias lombares que partem da aorta, sendo que cada artéria lombar chega a um vaso nutriente que penetra no corpo vertebral. Um ramo dorsal parte caudalmente, atrás dos processos articulares para a musculatura (SHARP; WHEELER, 2005).

A drenagem venosa é realizada pelo plexo venoso vertebral interno, também chamado sinus venoso, que consiste em duas tênues veias avalvulares (SHARP; WHEELEY, 2005; TOOMBS, 1992) estendidas ventrolateralmente ao longo da superfície ventral do canal vertebral, desde o crânio até a vértebra caudal. As paredes destas veias são finas e facilmente passíveis de lesão (SHARP; WHEELER, 2005). Na região tóraco-lombar, estas vasos divergem de cada espaço discal e convergem sobre o corpo vertebral, na porção média (JERRAM; DEWEY, 1999a). Ocorre então drenagem para as veias principais do tórax dorsal, principalmente veia ázigos, e na região lombar, para as veias principais do abdômen, principalmente veia ázigos e veia cava caudal (SHARP; WHEELEY, 2005). 
O plexo venoso drena pelo forame intervertebral através das veias intervertebrais para as veias vertebrais. As veias intervertebrais podem ser únicas em cada forame ou pareadas, sendo neste caso, encontradas ao redor do nervo espinhal (SHARP; WHEELEY, 2005).

Devido a dificuldades técnicas dos procedimentos cirúrgicos e ocorrência de hemorragia do plexo venoso, o cirurgião deve estar familiarizado com a anatomia do plexo venoso vertebral (TOOMBS, 1992).

A medula espinhal encontra-se dentro do canal vertebral e protegida pelas meninges: dura-máter, membrana aracnóide e pia-máter. O líquido cefalorraquidiano (LCR) está contido no espaço subaracnóideo (JERRAM; DEWEY, 1999a; SHARP; WHEELER, 2005; TOOMBS, 1992). A composição da medula espinhal é representada pela substância cinzenta central em forma da letra $\mathrm{H}$, composta pelos dois cornos dorsais e dois cornos ventrais, sendo formados primariamente de corpos celulares neuronais. Na periferia encontra-se a substância branca, composta principalmente por axônios, na maioria cobertos pela bainha de mielina formada pelos oligodendrócitos, justificando a sua coloração branca e dividida em funículos dorsal, lateral e ventral (CHRISMAN et al., 2005; SHARP; WHEELER, 2005).

O início da medula espinhal compreende o limite caudal do tronco encefálico, na região do forame magno, e o término na $6^{\mathrm{a}}$ vértebra lombar (L6) da maioria dos cães e na $7^{\mathrm{a}}$ vértebra lombar (L7) nos gatos, ocorrendo algumas variações. A medula espinhal e raízes nervosas dos nervos espinhais correspondentes são divididos em segmentos: cervical C1 a C8, torácico T1 a T13, lombar L1 a L7, sacral S1 a S3 e caudal Cd1 a Cd5 com variações. Pode-se observar que não se alinham diretamente com as vértebras de mesma numeração (CHRISMAN et al., 2005; SHARP; WHEELER, 2005).

Os números dos diferentes tipos de vértebras são: 7 cervicais, 13 torácicas, 7 lombares, 3 sacrais e aproximadamente 20 caudais, com possíveis variações nas regiões de transição, porém mais comumente em relação ao número de costelas e anormalidades na articulação com o ílio (SHARP; WHEELER, 2005). Os nervos espinhais penetram e saem entre as vértebras, formando o SNP do tronco e membros (CHRISMAN et al., 2005).

Os nervos sensoriais ou aferentes do SNP e do SNC são responsáveis pela transmissão dos sentidos especiais e também dos sentidos somáticos de dor, tato, temperatura e propriocepção (CHRISMAN et al., 2005). A informação sensorial é coletada do SNP através dos axônios sensoriais, cujos corpos celulares estão no gânglio espinhal ou gânglio da raiz dorsal, e que possuem projeções ascendentes da medula espinhal para o cérebro, constituindo os tratos sensoriais ascendentes, nomeados segundo o local de origem e término (CHRISMAN et al., 2005; SHARP; WHELER, 2005). 
A propriocepção é transmitida nos tratos da região dos funículos dorsal e lateral da medula espinhal, sendo que os axônios são projetados para a região do córtex somestésico cerebral ou cerebelo. Já a sensação térmica e de dor superficial são transmitidas por fibras mielinizadas de diversos tratos, como o espinotalâmico lateral. Por outro lado, a percepção da dor profunda ou nocicepção, é transportada pelas fibras não mielinizadas dos tratos proprioespinhal e espinoreticular, localizados na junção da substância cinzenta e branca, justificando o fato de que lesões na medula são extensas para afetar todas as fibras que transmitem a dor profunda. Porém fibras nociceptivas cruzam e recruzam a linha média, num arranjo multissináptico através da medula espinhal, originando um padrão difuso bilateral de fibras ascendentes do estímulo doloroso oriundos de cada membro (SHARP; WHEELER, 2005).

Os nervos motores ou eferentes promovem os movimentos dos músculos esqueléticos e lisos, sendo sua origem nos núcleos do encéfalo e tronco cerebral, descendo através de tratos motores, chamados tratos descendentes motores (CHRISMAN et al., 2005).

A função motora é transmitida através de dois sistemas: neurônios motores superiores (NMS), que formam os tratos motores, e neurônios motores inferiores (NMI). Na região cervical e intumescência lombar, há um alargamento da medula espinhal, por onde partem os NMI para a região dos membros torácicos (MT) e membros pélvicos (MP), constituindo os nervos periféricos (CHRISMAN et al., 2005; SHARP; WHEELER, 2005), que por sua vez inervam os músculos esqueléticos e viscerais (CHRISMAN et al., 2005).

A transmissão da informação até o cérebro, do grau de distensão da vesícula urinária, é realizada através do trato espinotalâmico. O esvaziamento voluntário da vesícula urinária é mediado através das fibras localizadas nos tratos motores, tectoespinhal e reticuloespinhal, na região do funículo ventral da medula espinhal (SHARP; WHEELER, 2005).

$\mathrm{O}$ arco reflexo é composto pelo nervo sensorial periférico e um neurônio efetor, representado pelo NMI, e sua conexão dentro de um segmento específico do tronco cerebral ou medula espinhal. O nervo sensorial chega até o corno dorsal da medula espinhal através da raíz dorsal e o NMI parte da raiz ventral do corno ventral da medula espinhal. A conexão de um NMS e um NMI é realizada por um interneurônio. Os reflexos espinhais são geralmente multissinápticos e incluem estes interneurônios, com exceção do reflexo patelar, que é monossináptico (CHRISMAN et al., 2005; SHARP; WHEELER, 2005). Portanto, se todos os componentes do arco reflexo estiverem funcionais, ocorrerá a sua manifestação, mesmo com danos severos ao NMS, como pode ocorrer nos segmentos espinhais T3-L3. Neste caso pode haver uma exacerbação dos reflexos dos MP, mimetizando um movimento voluntário em 
resposta a um estímulo mais ligeiro, fenômeno conhecido como caminhar espinhal (CHRISMAN et al., 2005).

O sistema do NMS é o efeito somatório de vários caminhos descendentes individuais, sendo que, de um modo geral, modera a atividade do NMI, além de iniciar o movimento voluntário e manter o tônus muscular normal. Em cães existe um trato motor ascendente originado das células marginais da substância cinzenta dorsolateral dos segmentos medulares L1 a L7, sendo que inibem os músculos extensores dos MT. Portanto, quando há alterações a este nível, geralmente em alguns casos agudos e severos do segmento espinhal torácico, ocorre a manifestação do sinal de Schiff-Sherrington.

O suprimento sanguíneo para a medula espinhal chega através das artérias espinhais, penetrando no canal vertebral na região do forame intervertebral. Ramificam-se em artérias radiculares dorsal e ventral, que suprem através de uma rede de anastomoses na superfície da medula espinhal, profundamente na dura-máter. Na região dorsal da medula espinhal, localizam-se as artérias espinhais dorsolaterais, que são pareadas. Na região ventral há a artéria espinhal ventral que percorre na fissura ventral. Existem artérias múltiplas que se anastomosam e conectam-se com os vasos principais. Além disso, várias outras artérias penetram na superfície medular, suprindo a substância branca e cinzenta. A drenagem venosa ocorre num padrão radial através da rede de veias na superfície, chegando até o plexo venoso vertebral interno no assoalho do canal vertebral, atingindo as veias intervertebrais no forame intervertebral (SHARP; WHEELER, 2005).

\subsubsection{Etiologia e fisiopatologia}

As primeiras descrições de discopatia intervertebral em humanos iniciaram em 1824, incialmente correlacionada a natureza neoplásica. Em 1932, a verdadeira natureza das protusões discais foram demonstradas. Já os relatos em veterinária sucederam-se em 1881, na espécie canina. Mas somente após 1940 diversos autores determinaram a degeneração do disco intervertebral e extrusão como causa de paraparesia e paraplegia em cães (BRAY; BURBIDGE, 1998).

As alterações degenerativas do disco intervertebral nas raças condrodistróficas ocorrem precocemente. Os discos intervertebrais destes cães sofrem metaplasia condróide aos 2 meses de idade e se completa ao redor de 1 ano de idade. Este processo envolve uma 
diminuição de glicosaminoglicanas e um aumento de colágeno. Este estudo sobre a composição estrutural do núcleo pulposo sugerem uma predisposição genética a doença degenerativa do disco interverterbral (COATES, 2000).

Enquanto o disco degenera, há desidratação e invasão por cartilagem hialina no núcleo pulposo. Após a degeneração do disco, ocorre a mineralização, mudando a característica gelatinosa para uma substância arenosa e seca, promovendo uma redução da propriedade hidrostática do núcleo pulposo e enfraquecimento das fibras do anel fibroso (NECAS, 1999; SHARP; WHEELER, 2005).

Outro tipo de degeneração discal, a metaplasia fibróide ocorre em outras raças e em animais idosos, devido a um aumento no conteúdo de glicoproteína não colagenosa, sendo raro a calcificação do disco (LECOUTEUR; CHILD, 1992). A degeneração do núcleo pulposo altera as propriedades mecânicas do disco e provoca microrupturas do anel fibroso que pode levar a uma saliência do anel dentro do canal vertebral (JANSSENS, 1992), nem sempre correlacionado a sinais clínicos. Ocorre também a desidratação do núcleo pulposo, mas a invasão é caracterizada por tecido fibrocartilaginoso (SHARP; WHEELER, 2005).

Além do fator genético, fatores mecânicos e anatômicos são importantes, sendo que o traumatismo pode levar a extrusão aguda do disco degenerado. Outros fatores propostos que podem contribuir são o hipotireiodismo e moléstia auto-imune (LECOUTEUR; CHILD, 1992), além da obesidade, integridade muscular e comprimento espinhal (JERRAM; DEWEY, 1999a).

Segundo Bray e Burbidge (1998), a discopatia intervertebral é relatada mais freqüentemente nas regiões de maior mobilidade da coluna vertebral em todos os animais. Observa-se que a discopatia intervertebral obedece as características típicas da mobilidade da coluna vertebral em cada espécie.

Podem ocorrer dois tipos de hérnia. A hérnia de Hansen tipo I ou extrusão acomete principalmente as raças caninas condrodistróficas entre 3 a 6 anos, devido a uma ruptura do anel fibroso dorsal e projeção do material do núcleo pulposo para dentro do canal vertebral, ocasionando uma compressão aguda ou mais lenta. A compressão de grau mínimo é associada a lesões inflamatórias. A compressão massiva determina importante compressão da medula espinhal e raízes nervosas. A hérnia de Hansen tipo II ou protusão ocorre freqüentemente em raças não condrodistróficas e de maior faixa etária, de 6 a 8 anos (COATES, 2000), tendo evolução lenta e provocando compressão na medula ou raízes nervosas além de reação local inflamatória (COATES, 2000; JANSSENS, 1992; LECOUTEUR; CHILD, 1992). 
A fisiopatologia da extrusão e protusão do disco intervertebral é bem descrita na literatura. Causam primariamente lesão da medula espinhal e sinais neurológicos clínicos pela concussão ou compressão (COATES, 2000). As injúrias tipo concussivas são caracterizadas por mudanças isquêmicas pós-traumáticas secundárias, sendo que os eventos seqüenciais envolvem hemorragia, edema e necrose neuronal (COATES et al., 1995).

Quando ocorre a extrusão aguda, há uma hemorragia significante do plexo venoso vertebral e uma reação inflamatória local pode resultar em aderências fibrinosas entre o material discal herniado e a dura-máter. Os discos intervertebrais das raças condrodistróficas sofrem mudanças degenerativas severas e rápidas, sendo atribuídas as diferenças estruturais destes animais em relação ao disco intervertebral (NECAS, 1999).

Janssens (1991) descreve como principal fenômeno fisiopatológico no trauma da medula espinhal, a ruptura de membranas celulares e microvasos, levando a formação de radicais livres, agregação plaquetária, obstrução de vasos, além da produção de tromboxanos, prostaglandinas e prostaciclinas. Ocorre, portanto, vasoconstricção, edema, anóxia celular e morte celular, sendo todo o processo completado dentro de 24 horas. Posteriormente ocorre o processo de regeneração.

O desenvolvimento da isquemia da medula espinhal é proposto como uma das causas fundamentais desta injúria tecidual secundária, desencadeado pela hipertensão sistêmica inicial, seguida dentro de 10 minutos de paralisia simpática e hipotensão por várias horas, na dependência da intensidade da injúria. Ocorre um progressivo decréscimo no fluxo sanguíneo da medula espinhal como resultado da perda da autoregulação, destruição da microvasculatura, formação de trombos e do vasoespasmo (OLBY, 1999).

Coughlan (1993) e Janssens (1991) citam também o aumento de íons de cálcio intraneuronal devido a ruptura da membrana celular. Além disso, com a injúria aguda da medula espinhal, há aumento de concentração de glutamato, um neurotransmissor excitatório, que liga-se ao complexo receptor de N-metil D-aspartato que é associado ao canal iônico e permite a entrada predominante de íons de cálcio, gerando mais lesão celular a nível de neurônios e axônios.

Estes efeitos afetam a substância cinzenta antes da branca e em lesões mais graves podem ocorrer por mais de 7 dias da injúria (OLBY, 1999), espalhando-se de forma centrífuga para a substância branca (COATES, 2000; COATES et al., 1995).

As fibras de diâmetro maior, ou seja, mielinizadas e de rápida condução, são as mais susceptíveis a injúrias, correspondendo a transmissão da propriocepção. Por outro lado, as fibras pequenas são as mais resistentes. As fibras mielinizadas intermediárias são as fibras 
motoras e as fibras mielinizadas de menor calibre e as não mielinizadas são as responsáveis pela transmissão da percepção dolorosa (SHARP; WHEELER, 2005).

Após 24 horas do trauma espinhal, há hiperemia da medula espinhal e perda da autoregulação do fluxo sanguíneo, ocorrendo fagocitose em poucos dias, atingindo um pico após 3 semanas. A remielinização inicia-se após uma semana e completa-se após 4 semanas. O edema persiste até 2 semanas e a deposição de cálcio é máxima do terceiro ao décimo quarto dia (JANSSENS, 1991).

Mudanças patológicas secundárias na medula espinhal incluem a mielopatia compressiva e mielomalácia com desmielinização dos funículos ventral, lateral e dorsal. Pode ocorrer a degeneração Walleriana nos segmentos espinhais acima e abaixo da lesão nos tratos ascendentes e descendentes. Como resultado do processo de degeneração neuronal há uma reação inflamatória formada primariamente por macrófagos e desenvolvimento de astrócitos fibrosos (COATES, 2000).

Com relação a mielomalácia, corresponde a uma liquefação da medula espinhal, sendo uma mielopatia autodestrutiva, com indício de ser um estágio final dos processos circulatórios e isquêmicos, estendendo-se do local do impacto a região ascendente ou descendente da medula espinhal. No entanto, sua patogenia é desconhecida, mas provavelmente reflexo de uma lesão extensa da vasculatura intramedular acompanhada por infarto hemorrágico ou não hemorrágico (COATES, 2000). Pode ocorrer excepcionalmente (JERRAM; DEWEY, 1999a) e é associada com a extrusão discal tipo 3 de Funkquist, caracterizada pela extrusão do núcleo disseminada ao longo de espaço epidural por uma distância de uma ou mais vértebras, podendo circundar ou penetrar a dura-máter. Há hemorragia nos espaços extradural e subaracnóideo e parênquima da medula espinhal (COATES, 2000).

\subsubsection{Sintomatologia}

Os sinais clínicos variam de acordo com a severidade da lesão, ou seja, do grau de compressão mecânica, hemorragia e/ou peroxidação lipídica seguida da isquemia da substância branca e cinzenta da medula espinhal, e em casos extremos, necrose (FERREIRA; CORREIA; JAGGY, 2002).

Embora a extrusão de disco intervertebral aguda geralmente acarreta em disfunção neurológica grave como paraparesia a paraplegia associada ou não a disfunção urinária, pode- 
se observar apenas dor na região espinhal, embora não tão intensa como ocorre na região de disco intervertebral cervical (JERRAM; DEWEY, 1999a; SHARP; WHEELER, 2005).

Segundo Braund (1986), a lesão tóraco-lombar entre T3 a L3 produz uma síndrome tóraco-lombar caracterizada por tônus muscular espástico, fraqueza ou paralisia dos membros pélvicos, com seus reflexos, patelar, tibial cranial e gastrocnêmio intactos, variando de normais a aumentados, correspondendo à lesão de neurônio motor superior, e nos membros torácicos normais. A sensibilidade cutânea é reduzida ou ausente abaixo da lesão e aumentada na região ou imediatamente após o nível da lesão. Se a lesão ocorre após L3, haverá sinais de lesão do neurônio motor inferior nos membros pélvicos, devido compressão da medula espinhal lombo-sacra ou nervos da cauda eqüina ou mielomalácea progressiva descendente (LECOUTEUR; CHILD, 1992). Cerca de 10 a 15\% dos animais podem apresentar lesão de neurônio motor inferior devido a lesões discais entre L3-L4 e L6-7 (SHARP; WHEELER, 2005). A doença de disco intervertebral tóraco-lombar constitui-se na principal causa de alteração neurológica em pequenos animais (OLBY; DYCE; HOULTON, 1994).

Segundo Shores e Roudebush (1992), as alterações locomotoras devido à disfunção motora voluntária podem resultar em paresia ou paralisia. Os termos podem ainda ser reclassificados em tetraparesia ou tetraplegia para descrever um animal com disfunção motora voluntária em todos os quatro membros, sendo devida a lesão cranial ao segmento espinhal T3. A paraparesia ou paraplegia corresponde a um animal com perda parcial ou completa, respectivamente, da função motora voluntária nos membros pélvicos, sendo o segmento espinhal envolvido correspondendo ao T3 ao S1, ou ainda lesão dos nervos periféricos dos membros pélvicos.

Pode-se classificar o paciente com discopatia intervertebral tóraco-lombar em diferentes graus de lesão, na dependência dos sinais clínicos e neurológicos presentes (JANSSENS, 1992; JERRAM; DEWEY, 1999a; OLBY; DYCE; HOULTON, 1994; YOYOVICH; EGER, 1994):

- GRAU 1 - presença de dor ou hiperestesia tóraco-lombar e sem deficiência neurológica. Os animais caminham devagar, relutam em pular ou subir escadas e algumas vezes apresentam constipação e cifose. Alguns vocalizam quando se movimentam ou são carregados. À palpação da região do dorso pode ser dolorosa devido a irritação das raízes nervosas e meninges, e a musculatura da região poderá estar espástica. 
- GRAU 2 - além dos sintomas anteriores, apresenta paraparesia, ataxia, deficiência proprioceptiva, presença da percepção da dor profunda, pode manifestar lesão de neurônio motor superior no membro pélvico.

- GRAU 3 - hiperalgesia tóraco-lombar, paraparesia e ausência de locomoção, percepção da dor profunda presente, pode ter retenção urinária e incontinência pelo volume urinário em excesso. Não são capazes de sustentar o peso e ficar em estação, mas possuem movimentos voluntários dos membros pélvicos. Pode manifestar lesão de neurônio motor superior no membro pélvico. Deficiência proprioceptiva.

- GRAU 4 - hiperalgesia tóraco-lombar, paraplegia e ausência de locomoção, ausência de movimentos voluntários, presença da percepção da dor profunda, pode apresentar retenção urinária e incontinência. Lesão de neurônio motor superior no membro pélvico. Deficiência proprioceptiva.

- GRAU 5 - hiperalgesia tóraco-lombar, paraplegia e ausência de locomoção, ausência de controle da micção e ausência da percepção da dor profunda. Lesão de neurônio motor superior no membro pélvico.

Sinais neurológicos assimétricos podem ocorrer, sendo este aspecto estudado em 50 cães com extrusão de disco intervertebral tóraco-lombar, após realização de mielografia e descompressão cirúrgica, demonstrando lateralização das lesões. Destes animais, subdivididos em grupo com sinais agudos e grupo com sinais crônicos, foram observados sinais neurológicos assimétricos em 35\% e 11\%, respectivamente (SMITH et al., 1997).

A progressão dos sinais clínicos ocorrem de acordo com o aumento da lesão medular e sua relação com envolvimento de fibras nervosas de diversos tamanhos. De acordo com este conceito, a perda da propriocepção ocorre em lesões médias. Lesões cada vez mais severas promovem perda da habilidade de sustentação, do movimento voluntário e no final, da percepção da dor profunda. Outro fator que é associado com a progressão de sinais clínicos, é a posição dos tratos espinhais. O trato proprioceptivo ascendente está mais superficial na medula espinhal e por este motivo mais sensível à injúria. Já os tratos espinotalâmicos e proprioespinhais ascendentes, que carreiam percepção de dor são localizados mais profundamente. A lesão medular deve envolver a maior parte do seu diâmetro para que seja afetada a percepção da dor profunda do paciente (SHARP; WHEELER, 2005), sendo um indicador de prognóstico grave (DUVAL et al., 1996). 
$\mathrm{Na}$ presença de mielomalácea, há sinais neurológicos que incluem a tetraplegia, arreflexia e analgesia, sendo que a perda ascendente do reflexo tronco-cutâneo ou panículo leva a suspeita de mielomalácea ascendente. Geralmente ocorre morte devido a falência respiratória dentro de poucos dias (COATES, 2000), entre 3 a 10 dias (JERRAM; DEWEY, 1999a). A incidência da mielomalácea corresponde de 3\% a 6\% em cães com discopatia intervertebral tóraco-lombar (COATES, 2000).

\subsubsection{Diagnóstico}

O diagnóstico inicial pode ser obtido através da combinação de sinais clínicos, história, exames clínico e neurológico, radiografias simples e contrastadas do canal medular ou seja, mielografia, além da tomografia computadorizada e ressonância magnética (COATES, 2000; DUVAL et al., 1996; LECOUTEUR; CHILD, 1992; SANDE, 1992; OLBY; DYCE; HOULTON, 1994).

Em relação ao diagnóstico diferencial, devem ser incluídos trauma, embolia fibrocartilaginosa, mielopatia degenerativa, discoespondilite, estenose lombosacra degenerativa, neoplasia e meningite (COATES, 2000; JERRAM; DEWEY, 1999a), além de outras causas que promovam dor abdominal (SHARP; WHEELER, 2005).

As radiografias devem ser realizadas de preferência após anestesia geral do animal, com projeções laterais e dorso-ventral. Podem ser observados estreitamento do espaço intervertebral em T10 e T11 até o segmento L4 a L6, material discal calcificado dentro do anel dorsal ou no canal medular, além de forma alterada do forame intervertebral, esclerose das bordas articulares e espondiloses (COATES, 2000; OLBY; DYCE; HOULTON, 1994).

Quando as radiografias simples não caracterizam bem a extrusão discal ou há discordância de localização neuroanatômica, presença de lesões múltiplas, indecisão entre tratamento médico ou cirúrgico ou indicação de cirurgia descompressiva, é realizada a técnica da mielografia. Ocorre opacificação do espaço subaracnóide e pode demonstrar a compressão extra-dural da medula espinhal (COATES, 2000; OLBY; DYCE; HOULTON, 1994). Alguns estudos citam que radiografias simples foram eficazes em 68 a $72 \%$ para identificar o local da extrusão discal e a mielografia em 86 a 97\% (COATES, 2000). Outro estudo indica que a mielografia lombar é superior do que radiografia simples em identificar a protusão discal tóraco-lombar (OLBY; DYCE; HOULTON, 1994). 
A tomografia computadorizada sozinha ou em conjunto com a mielografia é mais completa para identificar a lateralização do material discal que sofreu extrusão. Além disso, promove uma imagem diagnóstica quando há obstrução do fluxo do meio de contraste (COATES, 2000). Em um estudo, o uso da tomografia computadorizada e sem mielografia foi eficiente em identificar hemorragia e material discal herniado mineralizado (OLBY et al., 2000).

\subsubsection{Tratamento}

O tratamento objetiva alívio e remissão dos sintomas, além de evitar recidivas do processo. Diversos autores citam vários métodos de tratamento conservador e cirúrgico, envolvendo tratamento medicamentoso, acupuntura, repouso, antiinflamatórios, quimionucleólise e técnicas de descompressão cirúrgica (ALTMAN, 1992; JANSSENS, 1983, 1985, 1992; PADILHA FILHO; SELMI, 1999; STILL, 1989).

Muitos animais recuperam-se tanto com tratamento cirúrgico como não cirúrgico, inclusive com graus moderados de deficiência neurológica (SHARP; WHEELER, 2005).

O tratamento médico é usado em todos os casos de acometimento agudo de deficiência neurológica, para a diminuição do edema da medula espinhal, sendo utilizado corticosteróide (COUGHLAN, 1993; LECOUTEUR; CHILD, 1992). Em cães e gatos, o protocolo é: em caso agudo o tratamento deve ser instituído dentro de 8 horas do trauma, sendo indicado $30 \mathrm{mg} / \mathrm{kg}$ de succinato sódico de metilprednisolona por via venosa durante vários minutos, seguido de $15 \mathrm{mg} / \mathrm{kg}$ a cada 4 a 6 horas e não exceder 24 horas.

Em casos de tratamento cirúrgico em animais não submetidos anteriormente ao protocolo descrito, pode ser usado no momento da indução anestésica, na dose de $30 \mathrm{mg} / \mathrm{kg}$. Deve-se levar em conta os efeitos colaterais associados a estas altas doses (COUGHLAN, 1993). Outro autor cita a dosagem de $10 \mathrm{mg} / \mathrm{kg}$ de succinato sódico de prednisolona ou 2 $\mathrm{mg} / \mathrm{kg}$ de dexametasona por via venosa no pré-operatório imediato (YOVICH; READ; EGER, 1994). Janssens (1991), relata que após 24 horas, o tratamento deve ser centrado na regeneração tecidual.

O uso de manitol e dimetil sulfóxido é citado por alguns autores (COUGHLAN, 1993; DUVAL et al., 1996; FERREIRA; CORREIA; JAGGY, 2002), além de um composto de 21 - 
aminoesteróide, porém nenhum deles foi avaliado clinicamente, portanto não sendo recomendado o seu uso (JERRAM; DEWEY, 1999b).

O hormônio liberador de tirotropina tem efeitos neurotróficos e influência na plasticidade e facilidade de estímulo no neurônio motor, tornando sua aplicação promissora. O uso experimental em gatos e ratos com injúria medular demonstrou ser benéfico, inclusive em fase mais tardia. Mas seus análogos sintéticos devem ser mais estudados para evitar outros efeitos sistêmicos que este hormônio provoca no organismo (OLBY, 1999).

O tratamento médico conservador inclui repouso absoluto, em espaço limitado ou confinamento por no mínimo 2 semanas até 4 semanas, com a finalidade de cicatrização das fissuras do anel fibroso dorsal e evitar extrusão adicional do material discal. O uso de antiinflamatórios em conjunto ao repouso absoluto é controverso (JANSSENS, 1992; LECOUTEUR; CHILD, 1992).

Podem ser usados corticosteróides como dexametasona, prednisona e metilprednisolona, ou antiinflamatórios não esteroidais, além de relaxantes musculares como metilcarbamol e diazepam (BRAUND, 1986), monitoramento da micção e defecação, antibioticoterapia quando necessário (JANSSENS, 1992; LECOUTEUR; CHILD, 1992).

Chrisman et al.(2005) recomendam além do confinamento restrito por 4 semanas, a administração oral de 0,25 a $1 \mathrm{mg} / \mathrm{kg}$ de prednisona a cada 12 horas com diminuição da dosagem por 7 a 14 dias, com o intuito de reduzir o edema da medula espinhal devido a compressão, associa-se 5 a $10 \mathrm{mg} / \mathrm{kg}$ de cimetidina a cada 8 horas quando as doses de prednisona forem altas.

O confinamento restrito é importante principalmente se utilizado com medicação analgésica ou antiinflamatória. Após um período médio de 3 a 4 semanas, pode ser instituído atividade gradual entre a sexta e oitava semana (JERRAM; DEWEY, 1999b; SHARP; WHEELER, 2005), porém atividades como saltos devem ser evitados por 4 a 6 meses (SHARP; WHEELER, 2005).

O tratamento médico é reservado a animais com sinais de grau leve, com presença de dor, paraparesia média ou moderada, e proprietários sem condições financeiras (COATES, 2000), pacientes com perda da percepção da dor profunda por mais de 48 horas, animais com doença sistêmica e alto risco anestésico (JERRAM; DEWEY, 1999b). Segundo Braund (1986), os sinais clínicos médios resolvem-se após 3 semanas, mas a recorrência é comum. Coates (2000) cita que cães capazes de locomoção voluntária e que apresentem somente dor ou paresia de grau médio tem taxa de sucesso de $82 \%$ a $100 \%$, e que cães que não são capazes de locomoção voluntária tem taxa de sucesso de 43 a $51 \%$. 
Os resultados do sucesso no tratamento conservador podem ser resumidos, de acordo com a classificação já descrita em graus de lesão, em: 100\% em animais com grau 1, com tempo médio de recuperação de 3 semanas; $84 \%$ em animais com grau 2, com tempo médio de 6 semanas; 100\% em animais com grau 3, com tempo médio de 9 semanas; $50 \%$ em animais com grau 4, com tempo médio de 12 semanas e 7\% em animais com grau 5 com tempo médio de 4 semanas. Além disso, a recuperação é ao redor de $50 \%$ para animais com paraplegia e incontinência urinária, mas considerada ineficiente para animais com grau 5 (DAVIES; SHARP, 1983).

As indicações do tratamento cirúrgico incluem cães que não melhoram em 24 horas do tratamento médico, sinais recorrentes ou progressivos de dor e ataxia, paraplegia com presença da percepção da dor profunda ou com a perda num período menor que 24 horas a 48 horas. O tratamento cirúrgico também é instituído se há piora aguda das funções neurológicas, que incluem paresia, paralisia e função anormal da micção (COATES, 2000; LECOUTEUR; CHILD, 1992). Embora muitos veterinários considerem as extrusões discais como emergências cirúrgicas, ainda não foi bem estabelecido o período ideal para a descompressão cirúrgica (DAVIS; BROWN, 2002).

Há controvérsia sobre o tratamento em consideração a necessidade de cirurgia descompressiva, tipo de cirurgia descompressiva e a necessidade da retirada do material da extrusão, e o valor terapêutico da fenestração do disco (NECAS, 1999; PADILHA FILHO; SELMI, 1999). Ao se considerar a técnica descompressiva, não se deve esquecer que a deficiência neurológica pode ser devida pela concussão inicial. Entretanto o grau da compressão contínua pode freqüentemente ser avaliado somente com a tomografia computadorizada ou com a exploração cirúrgica (COUGHLAN, 1993).

As técnicas cirúrgicas citadas são a laminectomia dorsal, com ou sem durotomia, a hemilaminectomia, mini-hemilaminectomia, pediculectomia e fenestração do disco intervertebral (COATES, 2000; PADILHA FILHO; SELMI, 1999; SHARP; WHEELER, 2005).

Animais paraplégicos e com percepção da dor profunda intacta submetidos a cirurgia descompressiva com a técnica de hemilaminectomia e fenestração de pelo menos dois discos adjacentes obtiveram taxa de sucesso de $86 \%$, tendo em média a recuperação da capacidade de locomoção em 10,8 dias. Pacientes com evolução maior do que 6 dias tiveram um tempo prolongado para a recuperação da locomoção (FERREIRA; CORREIA; JAGGY, 2002).

Garret e Brown (2002) avaliaram 112 cães paraplégicos e com presença da percepção da dor profunda, submetidos a hemilaminectomia ou laminectomia dorsal. Observaram que 
96\% retornaram a locomoção com média em 12,9 dias. Um indicador de prognóstico favorável foi a presença de função motora voluntária no pós-operatório. Entretanto uma relação inversa foi encontrada entre tempo do início da paraparesia não ambulatória até o momento cirúrgico comparado ao tempo de locomoção, ou seja, vários animais submetidos rapidamente a cirurgia levaram um tempo maior para locomoção. Sugerem que é possível que o tempo de locomoção é completamente independente do tempo de evolução de sintomas antes da cirurgia ou que talvez os animais submetidos precocemente a cirurgia, são aqueles com declínio do quadro neurológico, embora neste estudo este quadro clínico não foi observado.

Olby et al. (2003) analisaram cães paraplégicos e sem percepção da dor profunda devido a trauma. Verificaram que eles têm prognóstico reservado. Os animais paraplégicos, sem percepção da dor profunda e devido extrusão de disco intervertebral, possuem chances melhores de recuperação da função motora após hemilaminectomia e fenestração de pelo menos um espaço.Um terço deles se recuperaram, mas não em relação a incontinência urinária. Outro fato observado foi que o movimento voluntário da cauda nestes animais recuperados, desenvolveu-se dentro de 4 semanas após a lesão. A média de retorno a locomoção foi de 7,5 semanas e 58\% dos animais retornou a dor profunda.

Um estudo retrospectivo de 30 casos de cães paraplégicos e sem percepção de dor profunda e submetidos a hemilaminectomia de um a cinco espaços intervertebrais observou que foi favorável em $76 \%$ dos casos, não relatando o tempo médio de retorno a locomoção. Todos os animais foram operados entre 6 a 120 horas de evolução dos sintomas (LIPPINCOTT, 1991).

Scott e McKee (1999) avaliaram 34 cães com discopatia tóraco-lombar com grau 5 após laminectomia e observaram que 62\% obtiveram resultado satisfatório e com retorno a locomoção, sendo que estes animais retornaram com a percepção dolorosa profunda em 2 semanas.

Padilha Filho e Selmi (1999) encontraram resultados satisfatórios em 29 cães com discopatia tóraco-lombar e submetidos a fenestração ventral, acesso por toracotomia intercostal, entre os espaços de T9-10 a L5-6. A média do tempo de recuperação dos cães com apenas dor lombar foi de 6 dias; para o grupo com paresia foi de 19,1 dias; para o grupo com paraplegia e presença de percepção da dor profunda foi de 20,6 dias e para o grupo com perda da percepção da dor profunda em menos de 24 horas foi de 30,6 dias, sendo a média geral para todos de 19 dias. Nos animais sem percepção da dor profunda $(n=5)$ observou-se recuperação em $80 \%$ dos casos. Não foi observado recorrência durante o período de estudo. 
Butterworth e Denny (1991) analisaram 100 cães com discopatia tóraco-lombar submetidos a fenestração lateral dos 3 últimos espaços intervertebrais torácicos e 3 primeiros lombares. Obteve taxa de sucesso de 92\% nos animais de grau $1(\mathrm{n}=12)$ com média de recuperação de 2,6 semanas; 93\% nos animais de grau $2(n=43)$ com média de 3,8 semanas; $85 \%$ nos animais de grau $3(\mathrm{n}=26)$ com média de 5,5 semanas; $88 \%$ nos animais de grau $4(\mathrm{n}=$ 8) com média de 8,3 semanas e $33 \%$ nos animais de grau $5(n=6)$ com média de 2,5 semanas; relata ainda a fenestração profilática em 5 animais com 100\% de sucesso. Não relatam a media de tempo de retorno a locomoção, somente o nível de recuperação.

A recuperação pós-operatória varia conforme o grau de comprometimento da medula espinhal, variando de 24 horas em casos menos severos, até um período de 2 a 3 meses em estados mais graves (YOVICH; READ; EGER, 1994).

Em relação a fatores que levam a recorrência de sinais clínicos, o tratamento médico das extrusões de disco leva a taxas maiores, cerca de um terço dos cães com recidivas e sinais clínicos mais graves (LECOUTEUR; CHILD, 1992). Em relação ao tratamento cirúrgico, a recorrência de sinais clínicos pode ocorrer devido acometimento de outro disco intervertebral, com taxas entre $2,6 \%$ a $26,5 \%$, sendo que cães que apresentem opacificação múltipla de discos no momento da primeira cirurgia representam uma subpopulação de alto risco (MAYHEW et al., 2004).

A ausência persistente da percepção da dor profunda indica lesão grave, mas não significa transecção completa da medula espinhal. A recuperação destes animais pode implicar no caminhar espinhal ou ainda sobrevivência de axônios cruzando o local da injúria. Acredita-se que o caminhar espinhal se origine de circuitos espinhais locais e tem sido demonstrada em cães adultos, gatos e roedores após transecção da medula espinhal. Foi demonstrado que uma sobra de 5 a 10\% de axônios descendentes é suficiente para determinar os circuitos locais que produzem a locomoção básica (OLBY et al., 2003).

\subsubsection{Acupuntura}

A acupuntura é considerada um método conservador de tratamento e pode ser utilizada para a analgesia, normalizar a função motora e sensorial e distúrbios de controle voluntário da micção (STILL, 1989). 
Historicamente, pela MTC, o relacionamento do Rim, como órgão energético e as estruturas ósseas e medula espinhal são explorados. Utilizam-se acupontos que estimulam o Rim, como os acupontos B23 e R3, e para a Medula, o acuponto VB39 (MACIOCIA, 1996). Segundo Rogers, Schoen e Limehouse (1992) alguns dos acupontos mais citados e usados em afecções do membro pélvico são E36, VB30, VB39, R3 e em afecções ósseas em geral são E36, B11. Schoen (1994) cita ainda para qualquer patologia em membro pélvico o ponto Bai Hui.

Pela MTC, quadros com sintomas de dor, sensibilidade ou parestesia correspondem a uma obstrução da energia nos Meridianos (MACIOCIA, 1996).

Segundo Wynn e Marsden (2003), a fraqueza nos membros pélvicos após protusão ou extrusão discal, envolve principalmente o Meridiano da Bexiga e secundariamente os Meridianos do Estômago e Vesícula Biliar. Os objetivos terapêuticos consistem em restabelecer o fluxo de energia através do Meridiano da Bexiga até os membros através da acupuntura. Os pontos citados e freqüentemente úteis são: B40, B60, B28, B54, VB30, F3, VB34, VB29, E38, VB39, além dos pontos acima e abaixo da obstrução.

Em afecções dos discos cervicais em cães, a acupuntura foi realizada uma vez por semana e casos apresentando sinais de dor intensa, duas vezes por semana, no total de 1 a 6 sessões, e tempo de duração de 15 a 20 minutos, sendo associado a tratamento medicamentoso, se necessário, e repouso por 30 dias. Os acupontos bilaterais utilizados foram: TA15, VB20, VB39, ID3 e IG11, além de pontos locais dolorosos a palpação na região cervical. Houve recuperação de $70 \%$ dos animais tratados, a grande maioria com sintoma único de dor, seguido de animais com dor e paresia e por último cães com dor e paralisia. A taxa de recidiva ocorreu em 37\% dos casos, segundo um follow-up de 4 meses a 8 anos. Mesmo após cirurgias e com persistência de dor, a acupuntura pode ser associada, porém não mostrou efeito profilático na recorrência (JANSSENS, 1985).

Estudo retrospectivo de 5 anos avaliou o tratamento com acupuntura em 75 cães com discopatia intervertebral tóraco-lombar e que anteriormente haviam sido tratados e não apresentaram evolução favorável. A recuperação ocorreu em $83 \%$ dos animais num período médio de 23 dias após o início da acupuntura, sendo o grupo de 12 animais que não apresentava percepção da dor profunda durante uma média de 18 dias previamente a acupuntura, apresentou uma recuperação de 58\% dos animais, em um período médio de 76 dias. A taxa de recidiva ocorreu em 4\% dos animais, avaliados de 8 meses a 5 anos após a acupuntura ter sido realizada. O grupo de 19 animais que apresentavam a percepção da dor profunda representaram a maioria dos resultados favoráveis no retorno a locomoção, em 
média 17,5 dias e número médio de 4,8 sessões e sucesso em $85 \%$ dos animais (JANSSENS, 1983)

Em 35 cães com discopatia tóraco-lombar em graus mais leves, somente dor ou dor e paresia, que foram tratados com acupuntura, apresentaram analgesia após o $1^{\mathrm{o}}$ tratamento em $68 \%$ dos casos. As funções sensoriais e motoras normalizaram em $48 \%$ dos cães após o $1^{\circ}$ tratamento. Porém com tratamentos repetidos, $83 \%$ obtiveram recuperação completa e em 14\% melhora significante (STILL, 1988).

Estudo experimental foi realizado em 20 cães submetidos à injúria da medula espinhal lombar, promovendo uma compressão de $25 \%$, e determinando paraparesia com capacidade de locomoção, ausência de propriocepção consciente e presença da percepção da dor profunda. Foram divididos em 4 grupos: A - tratamento com corticosteróide; B - tratamento com eletroacupuntura; $\mathrm{AB}$ - tratamento com eletroacupuntura e corticosteróide e $\mathrm{C}$ - grupo controle e sem tratamento. A eletroacupuntura, freqüência $25 \mathrm{~Hz}$ por 20 minutos, era realizada em dias alternados nos acupontos VG4 e E36, sendo usada também acupuntura tradicional com agulhas nos acupontos: VG3; B23; B24; VB30; VB34; E40 e E41. A recuperação da propriocepção ocorreu em média 8,2 $\pm 2,6$ dias e foi menor no grupo $\mathrm{AB}$ do que os outros grupos $(\mathrm{p}<0,05)$, sugerindo um efeito sinérgico de ação desta combinação terapêutica (JUNG-WHAN YANG et al., 2003).

Em afecções tóraco-lombares, a acupuntura pode ser utilizada em média uma vez por semana até duas vezes por semana e em casos crônicos a cada 15 dias, aliado a repouso e medicação se necessário. Os acupontos descritos variam de locais ao longo do meridiano da bexiga, de B17 a B28, correspondentes a T10 a L7, além de pontos locais do Meridiano do Vaso Governador, VG6, entre T12 a T13, e VG4, entre L1 e L2. Os acupontos distais são variáveis, como B40, B60, E36, VB30 e VB34, sendo utilizados para que fibras nervosas levem aferência até centros superiores e no segmento medular afetado, combatendo a inflamação, dor e ativando a regeneração. Outros acupontos usados são: R3 e R6, BP4 e BP6 , sendo a média de recuperação de 4 semanas para os graus 1 a 3 (JANSSENS,1983; 1992; STILL, 1989).

Estudo clínico sobre uso da acupuntura em cães com extrusão de disco intervertebral, e com ausência de dor profunda por mais de 48 horas e não submetidos a cirurgia, foi realizado em 25 cães. Os pontos locais variaram do B18 a B28, pontos distais VB30, VB34, E36, VB39, BP6, R3 e pontos extras denominados Baxie. A eletroacupuntura foi conectada nos pontos B20 e B23 ou B23 e B25 e VB30 e VB34 ipsilaterais, sendo as agulhas deixadas 
por 20 minutos e aplicadas duas vezes por semana até a recuperação da capacidade de andar. O tempo de recuperação variou de 3 semanas a 8 meses (SHIMUZU, 2003).

O mecanismo de ação da acupuntura em cães com discopatia intervertebral não foi plenamente estudado, mas pode-se relacionar vários aspectos. Acupuntura tem efeito analgésico, pode destruir pontos gatilho e abolir dor muscular e encurtamento, rigidez e dor referida. Pode ainda ativar regeneração de axônios destruídos na medula espinhal. Além disso, a acupuntura tem efeito antiinflamatório, diminuindo a inflamação medular, edema, vasodilatação ou constricção, liberação de histamina ou cinina (JANSSENS, 1992).

Yamamura (2001) cita os seguintes pontos para tratamento da discopatia intervertebral da região lombar em humanos: ID3 e B62, VG2 ou VG3 ou VG4, pontos extras chamados Huato Jiaji ou pontos locais dolorosos, VB30, B60, R3, e VB34 em casos de contratura. Também indica o tratamento com acupuntura na síndrome pós-laminectomia da região lombar, caracterizada por quadro álgico.

Ross (2003) relata tratamento acupuntural nos casos de protusão de disco em humanos, os pontos locais do Meridiano do Vaso Governador e pontos extras Huato Jiaji, além do uso de moxabustão ou da eletroacupuntura. Os acupontos distais como B40, VG 26, B40, R3, B62, B60, ID3 também podem ser usados.

A forma de localização dos acupontos é realizada através do seu relacionamento anatômico com músculos, tendões, ossos, nervos periféricos, vasos sanguíneos e segmentos medulares, além de suas funções energéticas abordadas de acordo com a MTC (DRAEHMPAEHL; ZOHMANN，1994; MACIOCIA，1996; WYNN; MARSDEN，2003; TORRO, 1997; YAMAMURA, 2001).

Segundo os autores citados, pode-se descrever os seguintes acupontos relacionados a discopatia intervertebral tóraco-lombar:

O acuponto ID3 ou Hou Xi está localizado na margem lateral da $5^{\text {a }}$ articulação metacarpo-falangeana, proximal à cabeça do $5^{\circ}$ osso metacarpiano (TORRO, 1997; WYNN; MARSDEN, 2003; YANN-CHING HWANG, 1992). Relaciona-se com o $5^{\circ}$ nervo digital dorsal palmar abaxial do ramo dorsal do nervo ulnar (DRAEHMPAEL; ZOHMANN, 1994). As indicações clínicas principais são dor cervical, do ombro e do cotovelo (WYNN; MARSDEN, 2003; YANN-CHING HWANG, 1992). É ponto principal que influencia os Meridianos do Intestino Delgado e Bexiga e a região posterior do pescoço e ombro. Uso em combinação com B62 para tratamento da região do canal do Vaso Governador, localizado principalmente na região da coluna vertebral (WYNN; MARSDEN, 2003). 
O acuponto B20 ou Pi Shu está presente lateral ao bordo caudal do processo espinhoso da $12^{\mathrm{a}}$ vértebra torácica, ao longo da linha longitudinal do tubérculo costal (WYNN; MARSDEN, 2003); a distância da largura de uma costela, lateral à extremidade inferior do processo espinhoso da $12^{\mathrm{a}}$ vértebra torácica (DRAEHMPAEHL; ZOHMANN, 1994); lateral a margem inferior do processo espinhoso da $11^{\mathrm{a}}$ ou $12^{\mathrm{a}}$ vértebra torácica (TORRO, 1997). Relaciona-se com o tronco cutâneo dorsal do $12^{\circ}$ nervo espinhal torácico (WYNN; MARSDEN, 2003; YANN-CHING HWANG, 1992); ramificações mediais da pele do ramo dorsal do $12^{\circ}$ e $13^{\circ}$ nervos intercostais e $12^{\mathrm{a}}$ artéria e veia intercostal e profundamente aos ramos musculares da $12^{\mathrm{a}}$ artéria e veia intercostal dorsal e do ramo dorsal do $12^{\circ}$ e $13^{\circ}$ nervos intercostais (DRAEHMPAEHL; ZOHMANN, 1994). As principais indicações são em discopatia intervertebral, desordens digestivas, pancreáticas, diabetes, pancreatite, anemias, vômitos (WYNN; MARSDEN, 2003; YANN-CHING HWANG, 1992).

O acuponto B23 ou Shenshu ou Ponto de Transporte Posterior do Rim (MACIOCIA, 1996; YAMAMURA, 2001), localizado lateral ao bordo caudal do processo espinhoso da $2^{\text {a }}$ vértebra lombar (DRAEHMPAEHL; ZOHMANN, 1994), ao longo da linha longitudinal do tubérculo costal torácico (WYNN; MARSDEN, 2003). Outra forma de localização: situado na ponta do processo transverso da $3^{\mathrm{a}}$ vértebra lombar, no entalhe entre os músculos longíssimo e íliocostal (YANN-CHING HWANG, 1992); a distância de uma largura de costela lateral à extremidade inferior do processo espinhoso da $2^{\text {a }}$ vértebra lombar (DRAEHMPAEHL; ZOHMANN, 1994). É relacionado com ramos ventrais do nervo espinhal do segmento L2, o que gera estimulação das fibras simpáticas via nervo esplâncnico maior e menor e suas partes para as supra-renais e rins (DRAEHMPAEHL; ZOHMANN, 1994). Relaciona-se também a ramos cutâneos dorsais do $2^{\circ}$ nervo espinhal lombar (WYNN; MARSDEN, 2003). As indicações clínicas principais são patologias renais, urogenitais, dor lombar, espondilose, displasia coxo-femoral, discopatia intervertebral (YANN-CHING HWANG, 1992; WYNN; MARSDEN, 2003). Fortalece a região lombar L2-3 (YAMAMURA, 2001).

O acuponto B25 ou $\mathrm{Da}$ Chang localiza-se lateral ao bordo caudal do processo espinhoso da $5^{\text {a }}$ vértebra lombar (WYNN; MARSDEN, 2003), ou na ponta do processo transverso do $5^{\mathrm{a}}$ vértebra lombar, no entalhe entre os músculos longuíssimo e íliocostal (YANN-CHING HWANG, 1992); a distância da largura de uma costela, lateral à extremidade inferior do processo espinhoso da $4^{\text {a }}$ vértebra lombar (DRAEHMPAEHL; ZOHMANN, 1994). Relaciona-se com ramo cutâneo dorsal do $5^{\circ}$ nervo espinhal lombar (WYNN; MARSDEN, 2003; YANN-CHING HWANG, 1992). As principais indicações clínicas são 
patologias gastrointestinais como constipação e diarréia, colite crônica, ponto local para discopatia tóraco-lombar (WYNN; MARSDEN, 2003; YANN-CHING HWANG, 1992).

O acuponto B60 ou Kun Lun situa-se na depressão entre o maléolo lateral da fíbula e a inserção do tendão do calcâneo comum a tuberosidade calcânea (DRAEHMPAEHL; ZOHMANN, 1994; WYNN; MARSDEN, 2003; YANN-CHING HWANG, 1992) ou a meia distância entre o ponto mais alto do maléolo lateral e o tendão do calcâneo (TORRO, 1997). Relaciona-se com o nervo sural cutâneo caudal (WYNN; MARSDEN, 2003; YANN-CHING HWANG, 1992) e mais profundamente o ramo sensível do nervo tibial, ramo caudal da veia safena lateral e mais profundamente com ramo caudal da artéria safena (DRAEHMPAEHL; ZOHMANN, 1994). As principais indicações clínicas são dor ou paralisia dos membros pélvicos (YANN-CHING HWANG, 1992), dor crônica do pescoço, ombro e região lombar (WYNN; MARSDEN, 2003). Regula a energia do canal da Bexiga, referido como "ponto aspirina" devido propriedades analgésicas (WYNN; MARSDEN, 2003). Relaxa os tendões e músculos (YAMAMURA, 2001).

O acuponto B62 ou Shen Mai está localizado numa depressão diretamente distal ao maléolo lateral da fíbula (DRAEHMPAEHL; ZOHMANN, 1994; TORRO, 1997; WYNN; MARSDEN, 2003). Relaciona-se com o nervo sural cutâneo caudal lateral, ramo caudal da veia safena lateral e ramos calcâneos do ramo superficial da artéria tibial cranial (DRAEHMPAEHL; ZOHMANN, 1994). As indicações clínicas principais são patologias do jarrete, inquietude, síndrome cervical, lombalgia, patologias do ombro (DRAEHMPAEHL; ZOHMANN, 1994). Relaxa músculos e tendões (YAMAMURA, 2001).

O acuponto E36 ou Zusanli, localiza-se em um aprofundamento lateral à crista tibial, na base do músculo tibial cranial (DRAEHMPAEHL; ZOHMANN, 1994); lateral à crista da tíbia, aproximadamente a largura de um dígito na face lateral do músculo tibial cranial (WYNN; MARSDEN, 2003); quando se traça uma linha do acuponto E35 (na região lateral da patela) ao E41 (na face dorsal da articulação do tarso), divide-se em 16 partes e toma-se a medida de 3/16 como correspondente a altura do acuponto E36 na base do músculo tibial cranial (TORRO, 1997). Relaciona-se com ramos do nervo safeno (WYNN; MARSDEN, 2003), nervo cutâneo lateral da sura, artéria e veia tibial cranial e fusos tendíneos e musculares do músculo tibial cranial (DRAEHMPAEHL; ZOHMANN, 1994); a nível profundo com o nervo fibular (WYNN; MARSDEN, 2003; YANN-CHING HWANG, 1992). As indicações clínicas principais são paralisia dos membros pélvicos, alterações gastrointestinais, analgesia acupuntural, efeitos em doenças endócrinas, doenças 
degenerativas como mielopatia degenerativa, doenças metabólicas (WYNN; MARSDEN, 2003; YANN-CHING HWANG, 1992).

O acuponto R3 ou Taixi, situa-se medialmente, a meia distância entre o maléolo medial e o tendão do calcâneo e se relaciona ao nervo tibial e artéria tibial posterior. Aprofundando-se a agulha atinge o ponto B60, Kunlun (MACIOCIA, 1996; YAMAMURA, 2001). Segundo Wynn e Marsden (2003) está relacionado com nervo safeno. As principais indicações clínicas são patologias urogenitais, cistite, enurese, doença renal crônica, dor lombar, ponto local para o calcanhar (WYNN; MARSDEN, 2003; YANN-CHING HWANG, 1992); paralisias dos membros inferiores, moléstias degenerativas (YAMAMURA, 2001).

O acuponto IG4 ou Hegu, está presente na extremidade medial do $2^{\circ}$ osso metacárpico, no meio da dobra da pele, após a abdução do $2^{\circ}$ dedo (DRAEHMPAEHL; ZOHMANN, 1994); entre o $1^{\circ}$ e $2^{\circ}$ ossos metacárpicos, ao nível da cabeça do $1^{\circ}$ metacarpo; se o $1^{\circ}$ osso metacarpiano estiver removido ou ausente, o acuponto estará na cicatriz, na face medial do $2^{\circ}$ metacarpo (WYNN; MARSDEN, 2003). Relaciona-se com a artéria, veia e nervo digital palmar dorsal II axial e artéria, veia, nervo digital palmar dorsal comum I e II. (DRAEHMPAEHL ; ZOHMANN, 1994). As principais indicações clínicas são doenças dermatológicas, dor cervical, neurodermatite. Acuponto mais importante que promove analgesia, benéfico para qualquer dor (WYNN; MARSDEN, 2003; YANN-CHING HWANG, 1992). Possue ainda indicações na paralisia facial, paralisia de membros torácicos, epilepsia, depressão, parto prolongado, urticária (YAMAMURA, 2001).

O acuponto extra Baihui ou Yao Bai Hui ou Bai Hui lombar ou VG20, no espaço lombo-sacro, sendo que nos humanos o VG20 localiza-se no topo da cabeça (YANN-CHING HWANG, 1992), nos animais situa-se na linha dorso mediana no limite entre o processo espinhoso do sacro e última vértebra lombar (WYNN; MARSDEN, 2003; YANN-CHING HWANG, 1992) ou segundo Draehmpaehl e Zohmann (1994), seria o acuponto VG3 na mesma localização citada. Relacionamento com ramo medial do $7^{\circ}$ nervo lombar (WYNN; MARSDEN, 2003; YANN-CHING HWANG, 1992). Relaciona-se com ramos dorsais e artéria lombar VII da artéria sacral mediana. Ponto importante para a metade posterior geral do corpo (DRAEHMPAEHL; ZOHMANN, 1994). As principais indicações clínicas são paralisia dos membros pélvicos, prolapso retal, alterações no nervo ciático, qualquer patologia lombar ou dos membros pélvicos (WYNN; MARSDEN, 2003; YANN-CHING HWANG, 1992).

O acuponto VB30 ou Huantiao, localiza-se caudodorsal ao trocanter maior, em um aprofundamento atrás da articulação coxo-femoral (DRAEHMPAEHL; ZOHMANN, 1994) 
ou ainda segundo Yamamura (2001) localiza-se no terço médio da linha traçada que passa pelo trocanter maior do fêmur e articulação sacro-coccígea. Segundo Yann-Ching Hwang (1992), há 3 formas de localização deste ponto: na depressão cranial ao trocanter maior do fêmur, chamado também de VB29 ou ainda na depressão dorsal ao trocanter maior, equivalente aos humanos, e para alguns chamado B54; e na linha média entre a protusão óssea da espinha ilíaca ventro-cranial, ou seja terminação caudolateral da tuberosidade da coxa, e o trocanter maior do fêmur, na depressão entre os músculos glúteo médio e tensor da fáscia lata; sendo este chamado VB30 (WYNN; MARSDEN, 2003). Segundo Draehmpaehl e Zohmann (1994) relaciona-se ao nervo isquiático e nervo glúteo caudal. Relacionado com nervo glúteo cranial, nervo cutâneo femoral lateral e ramos cutâneos dos nervos sacrais; o tronco do nervo ciático está profundo a este acuponto. As principais indicações clínicas são paralisia membros pélvicos, displasia coxo-femoral, alterações no ciático, artrite coxo-femoral (WYNN; MARSDEN, 2003; YANN-CHING HWANG, 1992). Fortalece a coluna vertebral da região lombar e membros inferiores, relaxa músculos e tendões (YAMAMURA, 2001).

O acuponto VG1 ou Hou Hai ou Chang Qiang localiza-se na região entre o ânus e a base da cauda. Relaciona-se profundamente aos músculos esfíncter anal externo e retococcígeo e aos ramos ventrais do nervo sacral e coccígeo. As principais indicações clínicas são diarréia, paralisa retal ou anal, prolapso retal e dor lombar (WYNN; MARSDEN, 2003; YANN-CHING HWANG, 1992), dor na região renal e da coluna vertebral. Fortalece a região lombar e mantém o $Q i$ dos orifícios inferiores, ou seja, ânus e uretra na interpretação da MTC (YAMAMURA, 2001).

Foi observado na revisão da literatura que os estudos clínicos já realizados com cães acometidos com discopatia intervertebral e tratados com acupuntura, não realizaram um grupo controle. Portanto, o objetivo primordial desta pesquisa foi a comparação entre pacientes tratados ou não pela acupuntura. 


\section{OBJETIVOS}

O presente estudo clínico e controlado teve como objetivo avaliar a eficácia da acupuntura associada ao tratamento médico em cães com afecção do disco intervertebral tóraco-lombar, direcionados a reabilitação motora e sensorial, comparando-se a animais que receberam tratamento médico, porém sem acupuntura. 


\section{MATERIAL E MÉTODOS}

Durante o período de março de 2005 a fevereiro de 2006 foram atendidos 134 cães de ambos os sexos, de diversas raças e idades, portadores de afecção da coluna vertebral, atendidos no Serviço de Cirurgia de Pequenos Animais da Faculdade de Medicina Veterinária e Zootecnia da Universidade de São Paulo.

Dentre estes animais foram selecionados para a pesquisa 61 cães que apresentavam afecção degenerativa do disco intervertebral da coluna tóraco-lombar.

O protocolo utilizado, número 636/2005, foi aprovado em 03 de maio de 2005 pela Comissão de Bioética da FMVZ/USP, e a inclusão dos pacientes no referido protocolo foi autorizada pelos proprietários.

Os animais foram divididos em dois grupos:

- Grupo 1 - 35 cães portadores de discopatia tóraco-lombar e submetidos à acupuntura associada a tratamento médico.

- Grupo 2 - 26 cães portadores de discopatia tóraco-lombar submetidos somente a tratamento médico.

Todos os animais foram medicados de acordo com a evolução clínica e grau de lesão neurológica no momento do atendimento no HOVET. Após exame clínico e neurológico, foram solicitados exames laboratoriais, e radiográficos da região da coluna vertebral tóracolombar.

O exame neurológico consistiu na avaliação dos reflexos espinhais, propriocepção consciente, capacidade de manter-se em estação, reflexo anal, panículo tronco-cutâneo, percepção da dor profunda e observação de retenção urinária e capacidade de locomoção.

Os casos agudos e apresentados ao hospital com até 24 horas de evolução eram medicados com succinato de metilprednisona na dose de 15 a $30 \mathrm{mg} / \mathrm{kg}$ por via venosa. Os pacientes com mais de 24 horas de evolução eram medicados com prednisona na dose de $1 \mathrm{mg} / \mathrm{kg}$ a cada 12 horas ou 24 horas durante 3 a 5 dias, seguido de doses decrescentes de $0,5 \mathrm{mg} / \mathrm{kg}$ a cada 24 horas durante 5 dias e após em dias alternados por mais 5 dias, adaptados conforme o tratamento prévio realizado por colega de outro estabelecimento. Casos onde ocorriam efeitos colaterais devido a doses elevadas de prednisona ou por outros corticosteróides administrados previamente a admissão no HOVET, foi prescrito ranitidina na dose de $2 \mathrm{mg} / \mathrm{kg}$ a cada 12 horas e fluidoterapia de suporte quando necessário, e encaminhamento do paciente ao Serviço de Pronto Atendimento Médico do HOVET. 
Animais com presença de dor na região tóraco-lombar foram medicados com dipirona na dose de $25 \mathrm{mg} / \mathrm{kg}$ a cada 8 horas e cloridrato de tramadol na dose de $2 \mathrm{mg} / \mathrm{kg}$ a cada 8 horas.

Procedimentos em relação ao manejo adequado da micção e defecação eram abordados, e se necessário realizados exames complementares e prescrito antibioticoterapia. Nos casos de retenção urinária com fácil esvaziamento, os proprietários foram instruídos a massagear pelo menos três vezes ao dia para estímulo da micção. Nos casos de retenção urinária com difícil esvaziamento por massagem, uma sonda uretral foi fixada por até 1 semana, sendo nestes casos instituído antibioticoterapia.

Todos os proprietários foram orientados quanto a necessidade do confinamento do animal e repouso absoluto por no mínimo de 30 dias, sendo alertado o risco de recidiva ou piora do quadro. Após o período de restrição e posterior melhora, os proprietários foram instruídos a evitar exercícios, caminhadas prolongadas e movimentos de saltar e pular (SHARP; WHEELER, 2005).

Animais com lesões de pele pelo atrito em piso rústico eram medicados com antibioticoterapia e higienização com antisséptico a base de triclosan e aplicação tópica de medicamentos para promover a cicatrização e combater infecções bacterianas secundárias.

Quando da evolução neurológica desfavorável e no aceite do proprietário os pacientes foram encaminhados para o tratamento cirúrgico.

\subsection{ACUPUNTURA}

Grupo 1:

- Aplicações ou sessões de acupuntura manual e eletroacupuntura, de acordo com as condições neurológicas de cada animal, realizadas com o animal em decúbito lateral esquerdo (Figuras 1 e 5).

- Foi utilizado aparelho de eletroestimulação ${ }^{3}$ (Figura 2), agulhas de acupuntura ${ }^{4}$ de aço inoxidável de dimensões $0,25 \mathrm{X} 25 \mathrm{~mm}$ (Figura 3).

- Os principais pontos foram pré-selecionados, variando em alguns casos de acordo com a condição da paraparesia ou paraplegia e presença ou não da percepção da dor

\footnotetext{
${ }^{3}$ Modelo DS100CB Sikuro

${ }^{4}$ Cloud \& Dragon
} 
profunda. Os acupontos utilizados foram: B20 e B23, ID3, B62, Bai Hui lombar, E36, R3/B60, e em alguns casos IG4, B25, VG1 e VB30. A escolha foi baseada nas funções energéticas pela MTC, relatos das pesquisas científicas e região segmentar medular influenciada pela aferência do estímulo sensorial.

- O estímulo acupuntural foi realizado uma vez por semana nos animais com presença da percepção da dor profunda.

- Nos cães sem percepção da dor profunda foi realizada acupuntura duas vezes por semana, nas primeiras duas semanas, posteriormente uma vez por semana.

- Um limite mínimo de 3 aplicações foi estabelecido. As agulhas permaneceram no local por 20 minutos, após inserção profunda e de acordo com a localização.

- Foi utilizada a estimulação das agulhas com eletroacupuntura, com as freqüências densa-dispersa de $3 / 100 \mathrm{~Hz}$, a intervalos de 3 segundos, com a duração total de 20 minutos, nos acupontos B20 e B23 ipsilaterais em ambos os lados ou B23 e B25 ipsilaterais em ambos os lados, Bai Hui lombar e VG1 ou Bai Hui lombar e VB30 do lado direito, E36 e R3/B60 ipsilaterais em ambos os lados.

- A localização dos acupontos (Figura 4) utilizados foi realizada de acordo com a descrição de Torro (1997) e Wynn e Marsden (2003).

\subsection{AVALIAÇÕES DOS PARÂMETROS DE EVOLUÇÃO CLÍNICA DOS SINTOMAS}

As avaliações clínicas foram realizadas mediante a observação da evolução dos sintomas, obedecendo a uma escala funcional numérica, que segundo Olby et al. (2003) foi superior a escala analógica visual em casos de animais com paraparesia ou paraplegia.

Outro fator relevante considerado foi a presença ou ausência da percepção da dor profunda, indicador da intensidade da lesão em medula espinhal (OLBY et al., 2003). A presença da percepção da dor profunda foi pesquisada aplicando pressão sobre o leito ungueal de um dígito (OLBY et al., 2001).

Foram anotados em dias ou semanas, o tempo em que o proprietário ou pesquisador observou a capacidade de locomoção sem necessidade de auxílio, mesmo com dificuldades, e avaliação do retorno da percepção da dor profunda. 
O proprietário também foi questionado sobre a melhora e/ou aparecimento de alguns sintomas no decorrer do tratamento, sendo anotado o tempo em dias em que foram observados.

A escala funcional numérica, em ordem crescente de evolução favorável, foi adaptada de Olby et al. (2003) para os seguintes parâmetros a serem avaliados no momento do atendimento e nos retornos, ou antes da sessão da acupuntura, quando esta foi realizada:

- Postura em estação:

0 = não se mantém em estação, mesmo com ajuda

1 = levanta-se e mantém-se em estação somente com auxílio para sustentação

2 = levanta-se e mantém-se em estação somente com auxílio e permanece por alguns segundos sozinhos sem auxílio

3 = levanta-se e mantém-se em estação somente com auxílio e permanece por vários segundos sozinhos sem auxílio

4 = levanta-se e mantém-se em estação sem necessidade de auxílio

- Movimentação dos membros pélvicos:

0 = ausência de movimentos

1 = movimento de um só membro pélvico e sem capacidade de locomoção

2 = movimento dos dois membros pélvicos e sem capacidade de locomoção

3 = movimento dos dois membros e com capacidade de locomoção, com apoio de um ou dos dois membros, com ataxia

4 = movimento dos dois membros e com capacidade de locomoção com apoio normal dos membros e sem quedas

- Presença de percepção da dor profunda:

0 = ausência de percepção da dor profunda

1 = presença questionável da percepção da dor profunda, necessidade de pesquisar vários dígitos ou a cauda, sendo detectado em uma das estruturas, porém com intensidade duvidosa

2 = presença discreta da percepção da dor profunda em um dígito e/ou cauda, vira o olhar e não manifesta choro

$3=$ presença da percepção da dor profunda em grau maior que anterior 4 = presença inquestionável da percepção da dor profunda

- Controle voluntário da micção:

$0=$ ausência de controle voluntário da micção- retenção ou incontinência 
1 = grau de incontinência razoável, quase o tempo inteiro

2 = grau de incontinência mediana, intermitente ou quando manipulado e necessidade de massagem para esvaziamento da urina residual

3 = controle voluntário esporádico e ausência de incontinência

4 = controle voluntário e sem deficiência

- Função motora ou capacidade de locomoção:

0 = ausência de função motora ou de locomoção

1 = locomoção somente quando sustentado pelo abdômen ou região inguinal

2 = locomoção sem sustentação, intermitente, e ataxia evidente

3 = locomoção sem sustentação na maior parte do tempo e ataxia ligeira ou em piso liso/escorregadio

4 = locomoção normal

Obs: os animais que encontravam-se numa fase entre o escore 3 e 4, eram atribuídos com graduação 3,5.

- Movimentação da cauda:

0 = ausência da movimentação voluntária da cauda.

1 = movimentação da cauda não voluntária.

2 = movimentação da cauda intermitente.

3 = movimentação normal da cauda.

Os valores dos escores totais variaram de 0 a 23 em ordem crescente de evolução neurológica favorável.

Para o proprietário foi solicitado que observasse e marcasse as datas ou tempo estimado dos seguintes eventos (NECAS, 1999):

- Recuperação da capacidade de locomoção sem assistência, no caso de animais com grau 3,4 e 5 .

- Descrição do grau de extensão da recuperação da função motora e urinária, em casos com deficiência.

- Fraqueza residual e/ou incoordenação.

- Recorrência de dor lombar, paresia ou paralisia.

- Recuperação do movimento voluntário da cauda.

Com relação a reabilitação das funções de micção urinária, propriocepção e locomoção foram classificados em níveis de recuperação: 
- RT: recuperação total da função de micção ou retorno da propriocepção e locomoção normal.

- RB: recuperação boa da função de micção com certo grau de incontinência quando animal fica agitado ou retorno parcial da propriocepção ou locomoção ligeiramente incoordenada, mas sem quedas.

- RD: recuperação discreta da função de micção ou melhora discreta da propriocepção ou locomoção incoordenada evidente, podendo ter quedas.

- SR: sem recuperação de nenhuma das funções, seja micção, propriocepção ou locomoção.

Os animais foram filmados a cada avaliação para eventuais dúvidas quanto ao grau de locomoção e movimentação dos membros.

\subsection{COLETA DE DADOS}

Aspectos demográficos dos animais encaminhados ao estudo foram coletados: sexo, idade, raça e peso. Aspectos clínicos foram coletados como início de evolução dos sintomas, local da lesão radiográfica, medicações prévias, grau de controle da micção urinária, presença de paraparesia ou paraplegia, movimentação da cauda, capacidade de se manter em estação, grau de locomoção, presença, ausência ou diminuição da propriocepção, retorno da locomoção, retorno da percepção da dor profunda, retorno do controle da micção, retorno da movimentação voluntária da cauda, escore da escala numérica funcional do estado neurológico, principais acupontos utilizados, presença ou ausência de sonolência, presença ou ausência de salivação ou secreção serosa ocular durante a sessão de acupuntura.

\subsection{MOMENTOS DE AVALIAÇÃO PARA ANÁLISE DOS TRATAMENTOS COM E SEM ACUPUNTURA}

Os dados foram agrupados em 4 momentos em relação a contagem total do escore da escala numérica funcional, consistindo em momento 0 , coletados no $1^{\circ}$ dia de avaliação pelo 
pesquisador; momento $7-7^{\circ}$ dia de tratamento; momento $14-14^{\circ}$ dia de tratamento e momento final - no dia em que foi dado alta ao animal. $\mathrm{O}$ mesmo pesquisador coletou as informações da escala funcional numérica.

\subsection{ANÁLISE ESTATÍSTICA}

Numa primeira etapa foi realizada análise estatística descritiva das variáveis clínicas.

O nível de significância adotado para a análise estatística deste estudo foi de $5 \%$.

Cada um dos momentos entre os grupos com acupuntura e sem acupuntura foram comparados através do teste não paramétrico de Mann Whitney para análise de 2 amostras independentes, pois as variáveis não tiveram as suposições de normalidade e homogeneidade das variâncias, não permitindo o uso de técnicas estatísticas paramétricas (NORMAN; STREINER, 2000). Foram analisados os momentos em relação à totalidade dos animais dos grupos com acupuntura e sem acupuntura e em relação aos graus de lesão dos grupos com acupuntura e sem acupuntura através do teste de Mann Whitney. Posteriormente pelo teste de Friedman para comparação múltipla de amostras dependentes, e caso fosse detectado diferenças significativas, realizou-se o teste de Wilcoxon para comparação de 2 amostras dependentes dentro de cada grupo, com acupuntura e sem acupuntura.

Para a análise do tempo de evolução dos sintomas nos animais com grau 1-2: com capacidade de locomoção; grau 3-4: cães sem capacidade de locomoção e presença da percepção da dor profunda; grau 5: animais sem capacidade de locomoção e sem percepção da dor profunda, foram comparados aos tratamentos com acupuntura e sem acupuntura, realizando-se teste não paramétrico de Mann Whitney.

No caso do tempo de retorno a locomoção nos animais com grau 3 e 4 foi comparado por teste paramétrico T-Student para 2 amostras não pareadas dos grupos sem acupuntura e com acupuntura, somente dos animais que recuperaram a locomoção. Para a análise do tempo de evolução dos animais referidos anteriormente e que retornaram a locomoção, foi realizado teste T-Student para 2 amostras não pareadas. Foi possível o uso de testes paramétricos para estas variáveis, pois obedeceram o critério de normalidade e homogeneidade das variâncias.

Para o resultado no tempo de retorno da movimentação voluntária da cauda foi realizado teste T - Student para 2 amostras não pareadas entre os dois tratamentos. 
Para os resultados da taxa de sucesso de uma forma geral entre os grupos tratamento com acupuntura e sem acupuntura foi realizado teste de Igualdade de Duas Proporções, sendo comparados os grupos com graus de lesão 3-4 e grau 5.

Para os resultados em relação aos níveis de recuperação com relação a micção, propriocepção e locomoção foram realizadas análise descritiva dos dados.

A análise estatística foi realizada em programa de computador (Graphpad Instat e Minitab 14). 


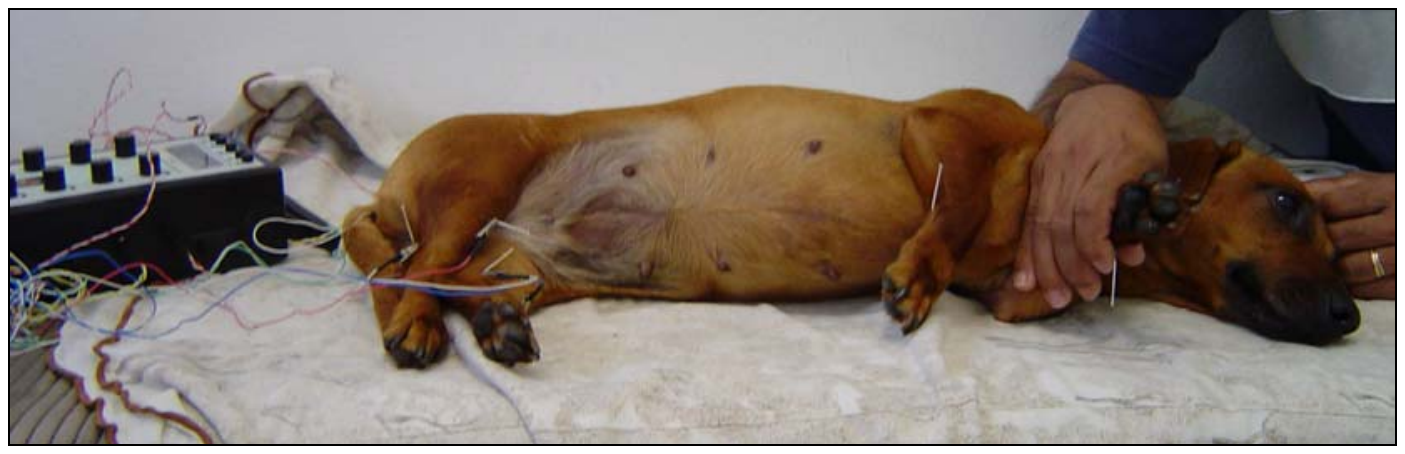

Figura 1 - Cão $\mathrm{n}^{\circ} 14$ em decúbito lateral esquerdo recebendo tratamento com eletroacupuntura percutânea nos acupontos E36 e R3/B60 nos membros pélvicos e acupuntura clássica no acuponto ID3 nos membros torácicos FMVZ/USP - São Paulo, 2006

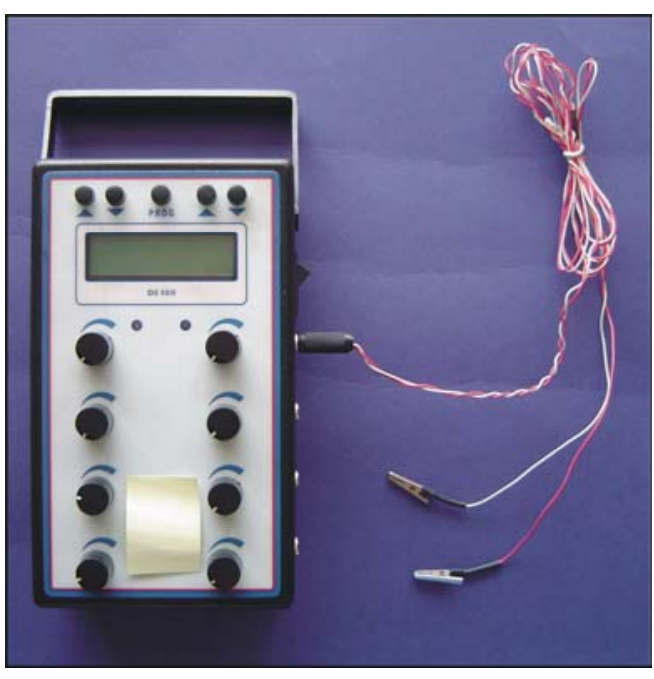

Figura 2 - Aparelho de eletroestimulação - FMVZ/USP São Paulo, 2006

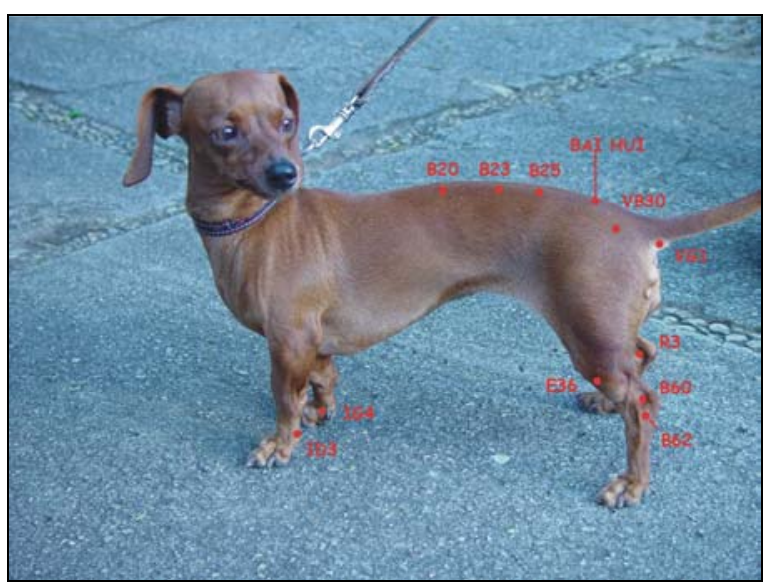

Figura 4 - Localização dos acupontos utilizados no presente estudo - FMVZ/USP - São Paulo, 2006

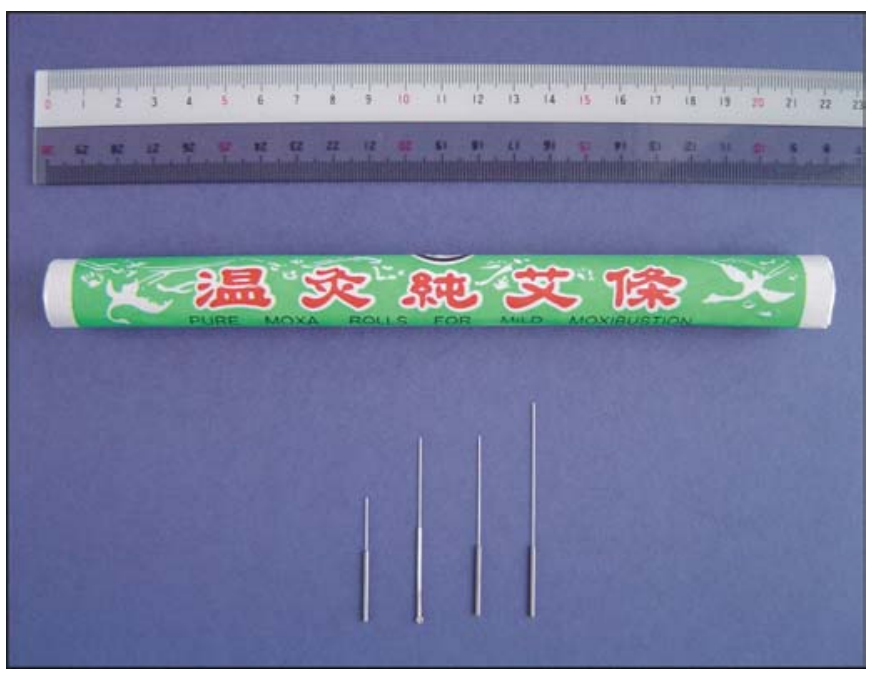

Figura 3 - Agulhas de acupuntura de diferentes tamanhos e bastão da erva Artemísia vulgaris - FMVZ/USP - São Paulo, 2006

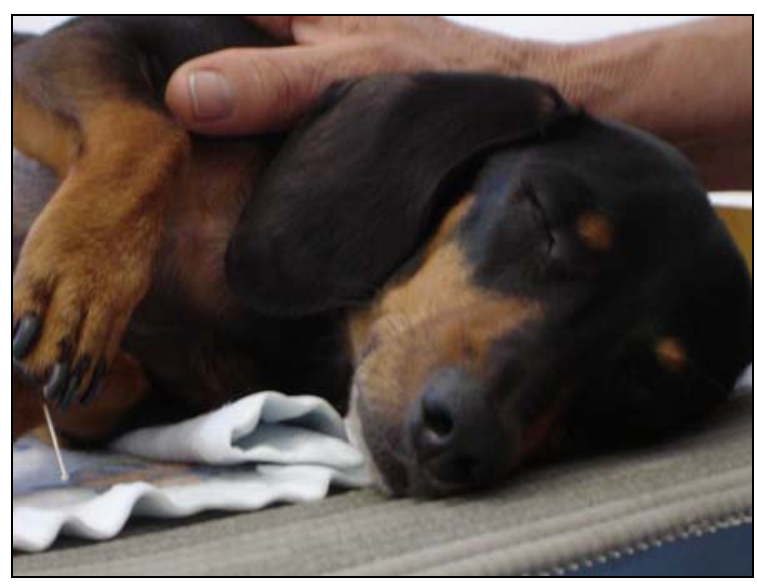

Figura 5 - Cão ${ }^{0} 22$ com aspecto de sonolência durante sessão de acupuntura - FMVZ/USP - São Paulo, 2006 


\section{RESULTADOS}

Foram incluídos no presente estudo 61 cães com afecção degenerativa do disco intervertebral tóraco-lombar, 31 machos (50,82\%) e 30 fêmeas (49,18\%). A idade média dos cães correspondeu a 5,76 $\pm 2,04$ (média \pm desvio padrão) anos, variando de 1 ano a 12 anos. O peso médio dos cães foi de $8,83 \pm 4$, sendo o mínimo de 2,1 e máximo de $24 \mathrm{~kg}$. O tempo de evolução dos sintomas variou de 1 dia a 120 dias, sendo a média de 16,68ะ19,22 (Apêndices A e B-Quadros 1 e 2). A raça mais acometida foi o Dachshund, seguido do Poodle, Cocker Spaniel, sem raça definida, Pequinês, Springer Spaniel e Lhasa apso (Tabela 1).

\begin{tabular}{c|cc} 
Tabela 1 - Porcentagem das raças de \\
cães - FMVZ/USP - São \\
Paulo, 2006 \\
\hline Raças & $\mathbf{n}^{\circ}$ de cães & $\%$ \\
\hline Dachshund & 45 & 72,6 \\
Poodle & 6 & 9,7 \\
Cocker Spaniel & 5 & 8,1 \\
sem raça definida & 3 & 4,8 \\
Pequinês & 1 & 1,6 \\
Springer Spaniel & 1 & 1,6 \\
Lhasa apso & 1 & 1,6 \\
\hline Total & 61 & 100 \\
\hline
\end{tabular}

Considerando-se a localização da extrusão através de métodos de diagnóstico por imagem e presença de acometimento de um espaço intervertebral principal observa-se que foram acometidos com maior freqüência a região T11-T12, seguidos das regiões T12-T13, T13-L1, L2-L3, L1-L2, T10-T11 (Tabela 2). 
Tabela 2 - Porcentagem da localização radiográfica da extrusão do disco intervertebral FMVZ/USP - São Paulo, 2006

\begin{tabular}{c|cc}
\hline & & \\
Disco Intervertebral & $\mathbf{n}^{\mathbf{0}}$ de cães & $\%$ \\
\hline T10-T11 & 1 & 3,12 \\
T11-T12 & 11 & 34,38 \\
T12-T13 & 8 & 25 \\
T13-L1 & 7 & 21,88 \\
L1-L2 & 2 & 6,25 \\
L2-L3 & 3 & 9,37 \\
\hline total & 32 & 100 \\
\hline
\end{tabular}

A análise de animais com localização radiográfica de extrusões em vários espaços revelou que a região torácica, compreendendo as regiões dos espaços intervertebrais T9-T10 a T12-T13 foram as mais acometidas, seguidas da região tóraco-lombar, entre T9-T10 a T13L1, e a região lombar, entre L1-L2 a L5-L6 (Tabela 3).

Tabela 3 - Porcentagem da localização das lesões múltiplas radiográficas - FMVZ/USP São Paulo, 2006

\begin{tabular}{c|cc}
\hline & & \\
Disco Intervertebral & $\mathbf{n}^{\mathbf{0}}$ de cães & $\%$ \\
\hline T9-10 a T12-13 & 15 & 65,22 \\
T9-10 a T13-L1 & 6 & 26,08 \\
& & \\
L1-2 a L5-6 & 2 & 8,7 \\
\hline total & 23 & 100 \\
\hline
\end{tabular}

Os animais encaminhados ao estudo foram distribuídos em dois grupos: 35 no grupo tratamento com acupuntura e 26 no grupo tratamento sem acupuntura.

Dentre os 61 animais, $8(13,11 \%)$ desistiram de continuar o tratamento, sendo 5 $(8,36 \%)$ do grupo acupuntura e $3(4,75 \%)$ do grupo sem acupuntura, 4 (6,55\%) foram eutanasiados por opção do proprietário em outro estabelecimento, sendo todos do grupo 
acupuntura (Apêndices C e D-Quadros 3 e 4). O cão 50 avaliado com lesão tóraco-lombar de grau 5, após recuperação da percepção da dor profunda, não teve sucesso na recuperação da locomoção por 3 semanas, passando a ser avaliado também no grupo de cães com grau de lesão tóraco-lombar grau 4, participando assim duas vezes do estudo (Apêndice B-Quadro 2).

A avaliação de todos os animais do estudo em relação a incidência dos graus de lesão, revelou predomínio do grau 5, seguido dos graus 4, 2, 3 e 1 (Tabela 4).

Tabela 4 - Porcentagem dos graus de lesão tóracolombar dos 62 animais do estudo FMVZ/USP - São Paulo, 2006

\begin{tabular}{c|cc}
\hline Grau & $\mathbf{n}^{\circ}$ cães & $\%$ \\
\hline 1 & 3 & 4,8 \\
2 & 14 & 22,6 \\
3 & 6 & 9,7 \\
4 & 19 & 30,6 \\
5 & 20 & 32,3 \\
\hline Total & 62 & 100 \\
\hline
\end{tabular}

Os animais incluídos na análise dos resultados totalizaram 50, sendo distribuídos em 26 no grupo tratamento com acupuntura e 24 no grupo tratamento sem acupuntura (Apêndices E e F-Quadros 5 e 6). Os pacientes foram agrupados segundo o grau de lesão, permaneceram no grupo 1, com acupuntura: 10 cães com graus 1 ou 2; 13 cães com graus 3 ou 4, sendo 3 excluídos da análise; 12 cães com grau 5, sendo 6 excluídos da análise. Permaneceram no grupo 2, sem acupuntura: 7 cães com graus 1 ou 2; 12 cães com graus 3 ou 4, sendo 3 excluídos da análise; 8 cães com grau 5, sendo que um animal foi para o grupo de grau 4, sendo avaliado duas vezes. Dos animais do grupo 2, sem acupuntura, com graus 3 ou 4, 3 foram excluídos da análise quanto ao tempo de retorno a locomoção, pois não tiveram sucesso em 3 semanas, sendo encaminhados a tratamento cirúrgico.

De acordo com a análise descritiva das medianas dos escores totais da escala funcional numérica do estado neurológico no momento 0 dos 62 cães do estudo, pode-se observar uma tendência similar entre os animais dos graus 1 e 2; graus 3 e 4 e isoladamente nos de grau 5 da lesão tóraco-lombar (Figura 6). 


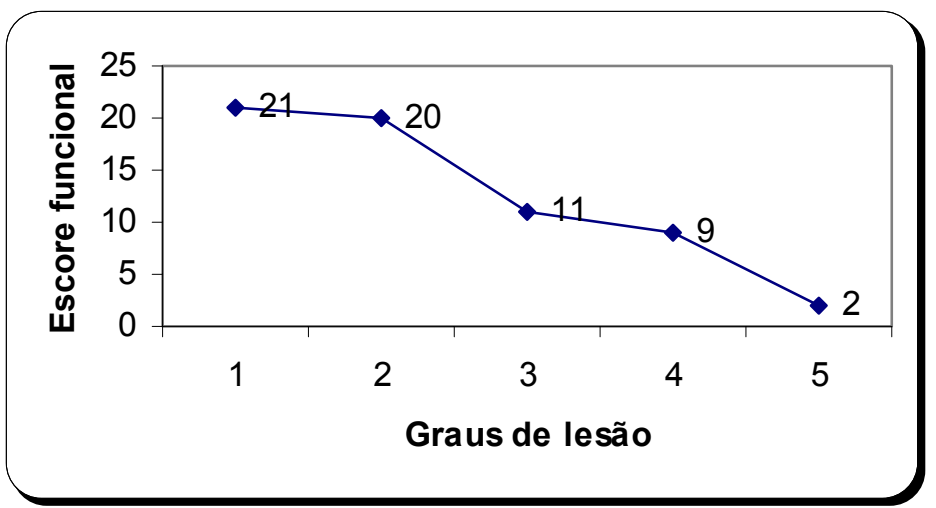

Figura 6 - Medianas do escore funcional no momento 0 da escala funcional numérica em relação aos graus de lesão tóraco-lombar dos 62 casos analisados FMVZ/USP - São Paulo, 2006

Os dados demográficos entre os grupos com acupuntura e sem acupuntura encontramse na tabela 5. O tempo de evolução dos sintomas até o momento 0 , independente do grau de lesão, foi comparado entre os grupos com acupuntura e sem acupuntura, que apresentaram diferença significativa (Tabela 5).

Tabela 5 - Dados demográficos em relação aos tratamentos com e sem acupuntura - FMVZ/USP - São Paulo, 2006

\begin{tabular}{|c|c|c|}
\hline Dados demográficos & $\begin{array}{l}\text { Grupo com } \\
\text { acupuntura }\end{array}$ & $\begin{array}{l}\text { Grupo sem } \\
\text { acupuntura }\end{array}$ \\
\hline Número animais & 26 & 24 \\
\hline Idade (anos) & $6,13 \pm 2,20$ & $4,79 \pm 1,61$ \\
\hline Macho & $13(50 \%)$ & $14(58,33 \%)$ \\
\hline Fêmea & $13(50 \%)$ & $10(41,67 \%)$ \\
\hline Peso (kg) & $8,52 \pm 3,27$ & $9,16 \pm 3,92$ \\
\hline Grau 1 & $2(7,69 \%)$ & $1(4,17 \%)$ \\
\hline Grau 2 & $8(30,77 \%)$ & $6(25 \%)$ \\
\hline Grau 3 & $3(11,54 \%)$ & $1(4,17 \%)$ \\
\hline Grau 4 & $7(26,92 \%)$ & $8(33,33 \%)$ \\
\hline Grau 5 & $6(23,08 \%)$ & $8(33,33 \%)$ \\
\hline $\begin{array}{l}\text { Tempo evolução* } \\
\text { (dias) }\end{array}$ & $21,77 \pm 17,70$ & $15,42 \pm 24,03$ \\
\hline \multicolumn{3}{|l|}{ Distribuição racial } \\
\hline Dachshund & $21(81,50 \%)$ & $16(66,67 \%)$ \\
\hline Cocker spaniel & $1(3,70 \%)$ & $4(16,67 \%)$ \\
\hline Springer spaniel & $1(3,70 \%)$ & 0 \\
\hline Poodle & $2(7,40 \%)$ & $3(12,5 \%)$ \\
\hline Pequinês & 0 & $1(4,16 \%)$ \\
\hline Sem raça definida & $1(3,7 \%)$ & 0 \\
\hline
\end{tabular}

${ }^{*} \mathrm{p}<0,037$ com nível de significância 5\% 
O tempo de evolução dos sintomas com relação ao tratamento com acupuntura e sem acupuntura e dependente do grau de lesão, mostrou diferença significativa $(p<0,016)$ no grupo de graus 1-2. Em relação ao grupo de grau 3-4, o tempo de evolução não mostrou diferença significativa $(p>0,346)$ entre os tratamentos. No grupo de grau 5 , o tempo de evolução também não demonstrou diferença significativa entre os tratamentos ( $p>0,953)$ (Tabela 6).

Tabela 6 - Tempo médio de evolução clínica em relação aos graus de lesão tóraco-lombar FMVZ/UP - São Paulo, 2006

\begin{tabular}{|c|c|c|c|}
\hline \multirow[b]{2}{*}{$\begin{array}{c}\text { Graus de } \\
\text { lesão }\end{array}$} & \multicolumn{2}{|c|}{ Tempo evolução (dias) } & \multirow[b]{2}{*}{$\begin{array}{c}\text { Grau de } \\
\text { significância } \\
\end{array}$} \\
\hline & $\begin{array}{c}\text { Com } \\
\text { acupuntura }\end{array}$ & $\begin{array}{c}\text { Sem } \\
\text { acupuntura }\end{array}$ & \\
\hline $1-2$ & $29,3 \pm 21,88$ & $7,57 \pm 6,08$ & $p<0,016$ \\
\hline $3-4$ & $15,8 \pm 10,02$ & $22,22 \pm 38,3$ & $p>0,346$ \\
\hline 5 & $19,17 \pm 18,21$ & $14,63 \pm 8,21$ & $p>0,953$ \\
\hline
\end{tabular}

Com relação aos cães que não possuíam capacidade de locomoção, mas com presença da percepção da dor profunda, compreendendo os graus 3 e 4, e que retornaram a locomoção, foram comparados em relação ao tempo de retorno a locomoção entre os grupos de tratamento com acupuntura e sem acupuntura, obtendo-se diferença significativa $(p<0,0341)$, sendo o grupo com acupuntura que apresentou um retorno a locomoção mais precoce do que o grupo sem acupuntura. Estes mesmos animais foram analisados em relação ao tempo de evolução clínica, e não se obteve diferença significativa $(\mathrm{p}>0,085)$ (Tabela 7).

Tabela 7 - Tempo médio de retorno à locomoção e evolução clínica do grupo grau 3 e 4 - FMVZ/USP - São Paulo, 2006

\begin{tabular}{c|ccc}
\hline Tempo Médio & $\begin{array}{c}\text { Com } \\
\text { acupuntura } \\
\mathbf{n = 1 0}\end{array}$ & $\begin{array}{c}\text { Sem } \\
\text { acupuntura } \\
\mathbf{n}=6\end{array}$ & $\begin{array}{c}\text { Grau de } \\
\text { significância }\end{array}$ \\
\hline $\begin{array}{c}\text { Retorno } \\
\text { locomoção } \\
\text { (dias) }\end{array}$ & $10,10 \pm 6,49$ & $20,83 \pm 11,99$ & $\mathrm{p}<0,0341$ \\
$\begin{array}{c}\text { Evolução } \\
\text { clínica (dias) }\end{array}$ & $15,8 \pm 10,02$ & $7,16 \pm 6,96$ & \\
\hline & & & $\mathrm{p}>0,085$ \\
\hline
\end{tabular}


A média dos escores totais da escala numérica funcional em relação aos momentos demonstrou na comparação geral dos grupos de tratamento com acupuntura e sem acupuntura, que no M0 não tiveram diferença significativa $(p>0,166)$, o mesmo ocorrendo no M7 $(p>0,069)$ e M14 $(p>0,080)$. No Mfinal $(p<0,007)$ houve diferença significativa entre os dois tipos de tratamentos (Tabela 8). Na análise de comparações múltiplas observou-se diferença significativa tanto nos momentos do grupo com acupuntura e sem acupuntura $(p<0,001)$. Na análise de comparações pareadas, observou-se que houve diferença significativa entre os momentos 0, 7, 14 e final dos grupos com acupuntura e em acupuntura (Tabela 9).

Tabela 8 - Média do escore funcional nos diferentes momentos em relação aos grupos tratamento com e sem acupuntura FMVZ/USP - São Paulo, 2006

\begin{tabular}{c|ccc}
\hline Momentos & $\begin{array}{c}\text { Com acupuntura } \\
(\mathbf{n}=\mathbf{2 6})\end{array}$ & $\begin{array}{c}\text { Sem acupuntura } \\
(\mathbf{n}=\mathbf{2 4})\end{array}$ & $\begin{array}{c}\text { Grau de } \\
\text { significância }\end{array}$ \\
\hline 0 & $12,79 \pm 6,72$ & $10,27 \pm 7,62$ & $\mathrm{p}>0,166$ \\
7 & $15,62 \pm 6,53$ & $11,75 \pm 7,43$ & $\mathrm{p}>0,069$ \\
14 & $17,65 \pm 6,10$ & $13,15 \pm 7,84$ & $\mathrm{p}>0,080$ \\
Final & $21,08 \pm 2,94$ & $15,58 \pm 8,23$ & $\mathrm{p}<0,007$ \\
\hline
\end{tabular}

Tabela 9 - Comparação pareada dos momentos e valores de $\mathrm{p}$ em relação aos grupos com e sem acupuntura - FMVZ/USP - São Paulo, 2006

\begin{tabular}{c|ccc|ccc}
\hline \multirow{2}{*}{ Momentos } & \multicolumn{3}{|c|}{ Com acupuntura } & \multicolumn{4}{c}{ Sem acupuntura } \\
\cline { 2 - 7 } & 0 & 7 & 14 & 0 & 7 & 14 \\
\hline \multirow{2}{*}{7} & $<0,001$ & & & 0,011 & & \\
14 & $<0,001$ & $<0,001$ & & 0,001 & 0,005 & \\
Final & $<0,001$ & $<0,001$ & $<0,001$ & $<0,001$ & $<0,001$ & 0,01 \\
\hline
\end{tabular}

O escore total da escala funcional numérica no grupo de cães com grau de lesão 1 e 2 avaliados em cada momento em relação ao tratamento com acupuntura e sem acupuntura não tiveram diferença significativa entre si em, sendo no M0 (p>0,702), M7 (p>0,764), M14 ( $p>0,508)$ e Mfinal ( $>>0,152)$ (Tabela 10). Na análise de comparações múltiplas observou-se diferenças significativas tanto no grupo com acupuntura $(p<0,001)$ e sem acupuntura $(\mathrm{p}<0,013)$. $\mathrm{Na}$ análise de comparações pareadas dos momentos no grupo com acupuntura observou-se diferença significativa em todos valores. Já no grupo sem acupuntura, não houve diferença significativa entre os momentos 0 e 7,7 e 14, 7 e final, 14 e final (Tabela 11). 
Tabela 10 - Média do escore funcional nos diferentes momentos em cães com grau 1 e 2 em relação aos grupos tratamento com e sem acupuntura - FMVZ/USP - São Paulo, 2006

\begin{tabular}{c|ccc}
\hline Momentos & $\begin{array}{c}\text { Com acupuntura } \\
(\mathbf{n}=\mathbf{1 0})\end{array}$ & $\begin{array}{c}\text { Sem acupuntura } \\
(\mathbf{n}=\mathbf{7})\end{array}$ & $\begin{array}{c}\text { Grau de } \\
\text { significância }\end{array}$ \\
\hline 0 & $20,05 \pm 2,11$ & $20,71 \pm 0,76$ & $\mathrm{p}>0,702$ \\
7 & $21,30 \pm 1,25$ & $20,86 \pm 1,89$ & $\mathrm{p}>0,764$ \\
14 & $21,95 \pm 1,04$ & $22,21 \pm 0,99$ & $\mathrm{p}>0,508$ \\
Final & $22,65 \pm 0,58$ & $22,21 \pm 0,76$ & $\mathrm{p}>0,152$ \\
\hline
\end{tabular}

Tabela 11 - Comparação pareada dos momentos e valores de $\mathrm{p}$ em relação aos cães com grau 1 e 2 nos grupos com e sem acupuntura - FMVZ/USP - São Paulo, 2006

\begin{tabular}{c|ccc|ccc}
\hline & \multicolumn{3}{|c|}{ Com acupuntura } & \multicolumn{4}{c}{ Sem acupuntura } \\
\cline { 2 - 7 } Momentos & 0 & 7 & 14 & 0 & 7 & 14 \\
\hline 7 & 0,026 & & & 0,527 & & \\
14 & 0,007 & 0,039 & & 0,02 & 0,068 & \\
final & 0,005 & 0,011 & 0,026 & 0,027 & 0,114 & 0,891 \\
\hline
\end{tabular}

O escore total da escala funcional nos diferentes momentos no grupo de cães com grau 3 e 4 revelou que não houve diferença significativa entre os grupos acupuntura e sem acupuntura no M0 (p>0,109) e no Mfinal ( $>>0,160)$. Já nos M7 ( $<<0,039)$ e M14 (p<0,020) houve diferença significativa entre os grupos de tratamento com acupuntura e sem acupuntura, o grupo com acupuntura apresentou as maiores médias (Tabela 12). A análise de comparações múltiplas mostrou diferença significativa no grupo com acupuntura $(p<0,001)$ e sem acupuntura $(\mathrm{p}<0,001)$. $\mathrm{Na}$ análise de comparações pareadas dos momentos encontrou-se diferença significativa no grupo com acupuntura em todos os valores. No grupo sem acupuntura observou-se diferença significativa, exceto entre os momentos 7 e 14 (Tabela 13).

Tabela 12 - Média do escore funcional nos diferentes momentos em cães com grau 3 e 4 em relação aos grupos tratamento com e sem acupuntura - FMVZ/USP - São Paulo, 2006

\begin{tabular}{c|ccc}
\hline Momentos & $\begin{array}{c}\text { Com acupuntura } \\
(\mathbf{n}=\mathbf{1 0})\end{array}$ & $\begin{array}{c}\text { Sem acupuntura } \\
(\mathbf{n}=\mathbf{9})\end{array}$ & $\begin{array}{c}\text { Grau de } \\
\text { significância }\end{array}$ \\
\hline 0 & $10,50 \pm 2,27$ & $8,67 \pm 2,78$ & $\mathrm{p}>0,109$ \\
7 & $15,10 \pm 4,28$ & $11,11 \pm 4,20$ & $\mathrm{p}<0,039$ \\
14 & $18,35 \pm 3,33$ & $13,28 \pm 4,21$ & $\mathrm{p}<0,020$ \\
Final & $21,45 \pm 1,28$ & $18,44 \pm 4,81$ & $\mathrm{p}>0,160$ \\
\hline
\end{tabular}


Tabela 13 - Comparação pareada dos momentos e valores de $p$ em relação aos cães com grau 3 e 4 nos grupos com e sem acupuntura - FMVZ/USP - São Paulo, 2006

\begin{tabular}{c|ccc|ccc}
\hline & \multicolumn{3}{|c|}{ Com acupuntura } & \multicolumn{4}{c}{ Sem acupuntura } \\
\cline { 2 - 7 } Momentos & 0 & 7 & 14 & 0 & 7 & 14 \\
\hline 7 & 0,014 & & & 0,042 & & \\
14 & 0,005 & 0,008 & & 0,028 & 0,068 & \\
final & 0,005 & 0,005 & 0,011 & 0,012 & 0,012 & 0,042 \\
\hline
\end{tabular}

Em relação aos cães com grau 5, o escore total da escala funcional numérica entre os grupos tratamento com acupuntura e sem acupuntura demonstrou diferença significativa somente no Mfinal ( $p<0,010)$, sendo que nos M0 ( $>00,398)$, M7 ( $>00,300)$ e M14 (p>0,195) não houve diferenças significativas (Tabela 14). A análise de comparações múltiplas demonstrou que o grupo com acupuntura teve diferença significativa $(p<0,001)$, ao contrário do grupo sem acupuntura que não mostrou diferença significativa $(p>0,060)$. Na análise de comparações pareadas no grupo com acupuntura observou-se diferença significativa entre todos os valores, ao contrário do grupo sem acupuntura que não teve diferença significativa (Tabela 15).

Tabela 14 - Média do escore funcional nos diferentes momentos em cães com grau 5 em relação aos grupos tratamento com e sem acupuntura - FMVZ/USP - São Paulo, 2006

\begin{tabular}{c|ccc}
\hline Momentos & $\begin{array}{c}\text { Com acupuntura } \\
(\mathbf{n}=\mathbf{6})\end{array}$ & $\begin{array}{c}\text { Sem acupuntura } \\
(\mathbf{n}=\mathbf{8})\end{array}$ & $\begin{array}{c}\text { Grau de } \\
\text { significância }\end{array}$ \\
\hline 0 & $4,5 \pm 3,15$ & $2,94 \pm 2,73$ & $\mathrm{p}>0,398$ \\
7 & $7,00 \pm 4,83$ & $4,50 \pm 3,82$ & $\mathrm{p}>0,300$ \\
14 & $9,33 \pm 6,55$ & $5,06 \pm 4,89$ & $\mathrm{p}>0,195$ \\
Final & $17,83 \pm 4,68$ & $6,56 \pm 6,95$ & $\mathrm{p}<0,010$ \\
\hline
\end{tabular}

Tabela 15 - Comparação pareada dos momentos e valores de $p$ em relação aos cães com grau 5 nos grupos com e sem acupuntura - FMVZ/USP - São Paulo, 2006

\begin{tabular}{c|ccc|ccc}
\hline \multirow{2}{*}{ Momentos } & \multicolumn{3}{|c|}{ Com acupuntura } & \multicolumn{3}{c}{ Sem acupuntura } \\
\cline { 2 - 7 } & 0 & 7 & 14 & 0 & 7 & 14 \\
\hline 7 & 0,043 & & & 0,131 & & \\
14 & 0,043 & 0,042 & & 0,131 & 0,285 & \\
final & 0,028 & 0,028 & 0,028 & 0,066 & 0,078 & 0,068 \\
\hline
\end{tabular}


O tempo médio de retorno a locomoção para os animais com grau 5 foi de 14,66 dias para aqueles que receberam acupuntura, correspondendo aos cães números 17, 21 e 25 (Apêndice E-Quadro 5) e um único animal do grupo sem acupuntura, retornou em 18 dias, correspondendo ao cão no 52 (Apêndice E-Quadro 6).

Os pacientes do grupo submetido ao tratamento com acupuntura apresentaram sonolência em 80,77\% (21) dos cães. Em 30,77\% (8) dos animais observou-se salivação e/ou secreção serosa ocular ou nasal.

As taxas de sucesso dos grupos com e sem acupuntura foram de 88,5\% e 58,3\%, respectivamente, sendo esta diferença significativa $(p<0,015)$. Nos cães com graus de lesão 1 e 2 , obteve-se $100 \%$ de sucesso nos dois grupos, acupuntura e sem acupuntura. Nos cães com graus de lesão 3 e 4, obteve-se 100\% de sucesso no grupo com acupuntura e 66,67\% no grupo sem acupuntura, sendo esta diferença significativa $(\mathrm{p}<0,047)$. Nos cães com grau de lesão 5 , obteve-se 50\% de sucesso no grupo com acupuntura e $12,5 \%$ de sucesso no grupo sem acupuntura, sendo esta diferença não significativa $(\mathrm{p}>0,124)$ (Tabela 16).

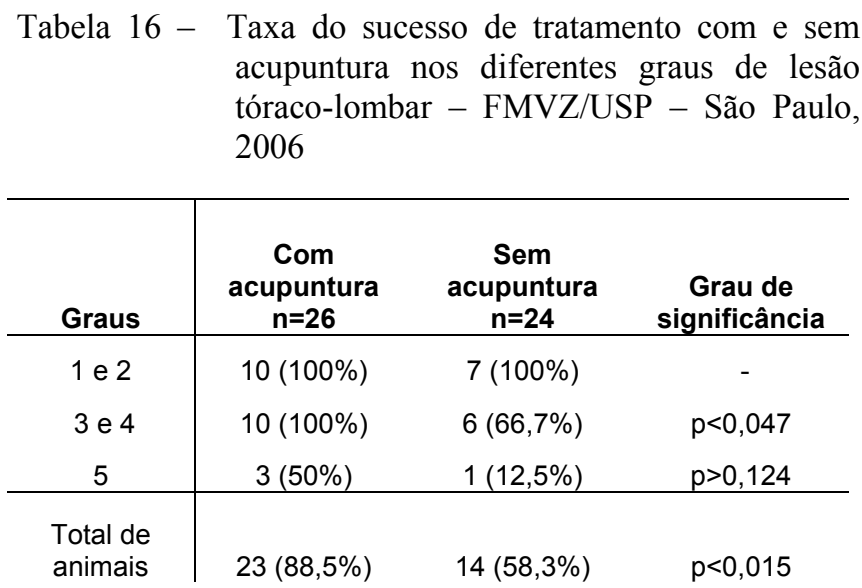

Durante o estudo não foram observadas recidivas dos sintomas nos cães do grupo com acupuntura. No grupo sem acupuntura foi observado recidiva após 4 meses da $1^{\text {a }}$ crise em apenas um animal, cão no 38, do grupo com lesão grau 1 e 2 (Apêndice E-Quadro 5).

Em relação ao tempo de retorno da movimentação voluntária da cauda, não se observou diferença significativa entre os animais tratados com acupuntura e sem acupuntura $(\mathrm{p}>0,27)$.

Quanto ao nível de recuperação, o grupo com acupuntura apresentou em relação a micção $40 \%$ (4) de recuperação total, $40 \%$ (4) de recuperação boa e $20 \%$ (2) sem 
recuperação; em relação a propriocepção 38,46\% (10) de recuperação total, 46,15\% (12) de recuperação boa, 7,69\% (2) de recuperação discreta e 7,69\% (2) sem recuperação; em relação a locomoção 34,61\% (9) de recuperação total, 50\% (13) de recuperação boa, 11,53\% (3) de recuperação discreta e 3,84\% (1) sem recuperação. O grupo sem acupuntura apresentou em relação a micção 16,66\% (2) de recuperação total, 33,33\% (4) de recuperação boa e 50\% (6) sem recuperação; em relação a propriocepção 29,16\% (7) de recuperação total, 25\% (6) de recuperação boa e 45,83\% (11) sem recuperação; em relação a locomoção 4,16\% (1) de recuperação total, 54,17\% (13) de recuperação boa e 41,67\% (10) sem recuperação.

No geral a recuperação no grupo com acupuntura em relação à micção foi de $80 \%$ (8), propriocepção foi de $92,30 \%$ (24) e locomoção foi de 96,14\% (25). No grupo sem acupuntura, a recuperação no geral em relação à micção foi de 49,99\% (6), propriocepção foi de $54,16 \%$ (13) e locomoção foi de 58,33\% (14) (Tabela 17).

Tabela 17 - Níveis de recuperação da micção, propriocepção e locomoção dos 50 animais do estudo - FMVZ/USP - São Paulo, 2006

\begin{tabular}{c|ccc|ccc}
\hline Grupos & \multicolumn{3}{|c|}{ Com acupuntura } & \multicolumn{3}{c}{ Sem acupuntura } \\
\hline Níveis & Micção (n=10) & $\operatorname{Prop}^{1}(\mathrm{n}=26)$ & $\operatorname{Loc}^{2}(\mathrm{n}=26)$ & Miç̧ão $(\mathrm{n}=12)$ & $\operatorname{Prop}^{1}(\mathrm{n}=24)$ & Loc $^{2}(\mathrm{n}=24)$ \\
\hline $\mathrm{RT}^{3}$ & $4(40 \%)$ & $10(38,46 \%)$ & $9(34,61 \%)$ & $2(16,66 \%)$ & $7(29,16 \%)$ & $1(4,16 \%)$ \\
$\mathrm{RB}^{4}$ & $4(40 \%)$ & $12(46,15 \%$ & $13(50 \%)$ & $4(33,33 \%)$ & $6(25 \%)$ & $13(54,17 \%)$ \\
$\mathrm{RD}^{5}$ & 0 & $2(7,69 \%)$ & $3(11,53 \%)$ & 0 & 0 & 0 \\
$\mathrm{SR}^{6}$ & $2(20 \%)$ & $2(7,69 \%)$ & $1(3,84 \%)$ & $6(50 \%)$ & $11(45,83 \%)$ & $10(41,67 \%)$ \\
\hline$\%$ & & & & & & \\
Recuperação & & & & & \\
geral & $80 \%$ & $92,30 \%$ & $96,14 \%$ & $49,99 \%$ & $54,16 \%$ & $58,33 \%$ \\
\hline
\end{tabular}

${ }^{1}$ Prop: propriocepção; ${ }^{2}$ Loc: locomoção; ${ }^{3} \mathrm{RT}$ : recuperação total; ${ }^{4} \mathrm{RB}$ : recuperação boa; ${ }^{5} \mathrm{RD}$ : recuperação discreta; ${ }^{6} \mathrm{SR}$ : sem recuperação

Os principais acupontos utilizados para os animais de grau 1 e 2 foram ID3, B62, E36, R3/B60, B20, B23, Bai Hui lombar e VB30, sendo que em animais com paraparesia acentuada ou alterações na micção, o acuponto VB30 era substituído por VG1; o animal 4 apresentava-se com hiperadrenocorticismo em fase de controle do tratamento (Apêndice IQuadro 9).

Nos cães com grau 3 e 4 foram utilizados os acupontos ID3, B62, E36, R3/B60, B20, B23, Bai Hui lombar e VG1, sendo que no animal 24, em algumas sessões substituiu-se o B20 pelo B25 devido suspeita de acometimento de disco intervertebral posterior a L2-3 e 
substituição do VG1 pelo VB30 em algumas sessões. No animal 22 não foi realizada eletroacupuntura, apresentando-se com diagnóstico provável de aplasia medular, sendo utilizada acupuntura clássica tradicional com inserção de agulhas nos acupontos IG4, B62, E36, R3/B60, B20, B23 e Bai Hui lombar; e no animal 20, substituiu-se os acupontos ID3 e B62 pelo acuponto IG4, pois o animal não permitiu inserção dos referidos acupontos (Apêndice J-Quadro 10).

Nos cães com grau 5, os acupontos utilizados foram ID3, B62, E36, R3/B60, B20, B23, Bai Hui lombar e VG1, sendo que no animal 25, o acuponto B20 foi substituído pelo B25 devido lesão radiográfica em disco intervertebral L4-5 (Apêndice K-Quadro 11).

Em relação ao grupo tratamento com acupuntura também obteve-se os seguintes dados nos cães com grau 1 e 2 que apresentaram um número de 3,4 $\pm 1,265$ de sessões para o retorno de pelo menos em um membro pélvico da propriocepção e número total de 5,2 $\pm 2,34$ sessões. Para os cães com grau 3 e 4, apresentaram um número de 2,4 $\pm 1,17$ sessões para o retorno da propriocepção, 2,2 \pm 0,95 sessões para o retorno da locomoção e número total de sessões de $7,1 \pm 3,57$. Para os cães com grau 5 , obteve-se o resultado de 5,6 $\pm 1,52$ sessões para o retorno da propriocepção, sendo que este ocorreu em 3 animais, $5 \pm 2,65$ sessões para o retorno a locomoção, sendo que este ocorreu também em 3 animais e o número total de sessões foi de $10,66 \pm 4,36$ (Tabela 18). Observou-se também que nos cães $n^{\circ} 18$ e 19, com grau de lesão 5 , ocorreu o fenômeno de caminhar espinhal intermitente, sendo este mais evidente com auxílio de aparelho de sustentação ou carrinho para cães paraplégicos (Apêndice E-Quadro 5).

\section{Tabela 18 - Número de sessões para retorno da propriocepção, locomoção e total de sessões nos 26 cães do tratamento com acupuntura - FMVZ/USP - São Paulo, 2006}

\begin{tabular}{c|ccc}
\hline & \multicolumn{3}{|c}{ Acupuntura } \\
\cline { 2 - 4 } Graus & $\begin{array}{c}\text { Número sessões } \\
\text { para retorno } \\
\text { propriocepção }\end{array}$ & $\begin{array}{c}\text { Número sessões } \\
\text { para retorno } \\
\text { locomoção }\end{array}$ & $\begin{array}{c}\text { Número } \\
\text { total } \\
\text { sessões }\end{array}$ \\
\hline $\begin{array}{c}1 \text { e } 2 \\
(\mathrm{n}=10) \\
3 \text { e } 4 \\
(\mathrm{n}=10) \\
5\end{array}$ & $3,4 \pm 1,265$ & - & $5,2 \pm 2,34$ \\
$\left(\mathrm{n}=6^{*}\right)$ & $2,4 \pm 1,17$ & $2,2 \pm 0,95$ & $7,1 \pm 3,57$ \\
\hline${ }^{*} \mathrm{n}=3$ que conseguiram recuperação da propriocepção e locomoção
\end{tabular}

As medicações utilizadas previamente à admissão ao HOVET e após o momento 0 encontram-se resumidas no quadro 7 do apêndice $\mathrm{G}$ e quadro 8 do apêndice $\mathrm{F}$. 


\section{DISCUSSÃO}

Os autores relataram as raças condrodistróficas como as mais susceptíveis a discopatia tóraco-lombar (COATES, 2000; NECAS, 1999; OLBY; DYCE; HOULTON, 1994). Os dados do presente estudo confirmaram estes achados, mostrando que a raça mais prevalente foi o Dachshund, seguido do Poodle e Cocker Spaniel.

A região mais acometida e detectada por método de diagnóstico por imagem compreendeu de T9-10 a T13-L1 em relação a lesões múltiplas $(91,10 \%)$ e isoladamente nos espaços T11-12, T12-13 e T13-L1, totalizando 81,26\%, correspondendo muito próximo aos dados já descritos em literatura (BRAUND, 1986; BRAY; BURBIDGE, 1998; NECAS, 1999; YOVICHI; READ; EGER, 1994).

Segundo diversos autores o pico de acometimento ocorre entre 4 a 6 anos de idade (BUTTERWORTH; DENNY, 1991; DAVIES; BROWN, 2002; PADILHA FILHO; SELMI, 1999; STILL, 1988). A idade média de 5,76 anos encontrada neste estudo confirmam os dados obtidos por outros estudos.

A discopatia intervertebral tóraco-lombar promove estados dolorosos e muitas vezes debilitantes, caracterizando sinais clínicos neurológicos variáveis, ocorrendo desde uma leve hiperestesia da região, paraparesia de graus variados até paraplegia e alterações na micção, com perda da capacidade de locomoção, atingindo o nível mais grave com a perda da percepção da dor profunda. De acordo com diversos autores, esta variabilidade de sintomas e sinais permite a classificação em graus de lesão neurológica e estabelecendo critérios para $\mathrm{o}$ tratamento e prognóstico (BRAY; BURBIDGE, 1998; COATES, 2000; JANSSENS, 1992; JERRAM; DEWEY, 1999a; PADILHA FILHO; SELMI, 1999; SHARP; WHEELER, 2005). Esta variabilidade também foi encontrada nos animais encaminhados ao estudo, obtendo-se amostragem para cada grau de lesão, estabelecida em grau 1 a 5 . Considerando a ordem crescente de gravidade, houve predomínio dos casos mais debilitantes, ou seja, graus 4 e 5.

Portanto, comparar a melhora clínica do tratamento com a presença de vasta diferença em relação ao estado neurológico de animais com discopatia tóraco-lombar, torna a necessidade de se estabelecer critérios para transformar a amostragem de uma forma mais homogênea e passível de realização de confrontos. O estabelecimento da escala funcional numérica com seus escores foi importante para determinar uma similaridade entre os graus de lesão e permitiu agrupamento entre os graus 1 e 2; graus 3 e 4 e isoladamente o grau 5, através da análise das medianas dos escores totais encontrados em cada grau já referido. 
Através deste agrupamento foi viável a comparação do tratamento médico associado com acupuntura e sem acupuntura.

Em relação aos grupos com acupuntura e sem acupuntura, encontra-se homogeneidade razoável no que se refere ao tamanho da amostra, idade, sexo, peso, distribuição racial, e graus de lesão. Somente em relação ao tempo de evolução clínica considerando todos os graus de lesão, o grupo com acupuntura apresentou casos com evolução crônica.

Mas ao analisar o agrupamento em graus, somente no grupo de grau 1 e 2 houve diferença significativa, onde o grupo de tratamento com acupuntura obteve tempo de evolução clínica mais crônico, e nos grupos de grau 3 e 4, e grau 5, não houve diferença significativa, o que permitiu a comparação entre os tratamentos em relação ao tempo de retorno a locomoção em dias nos referidos grupos.

A evolução crônica em animais de grau 2 foi observada também por Yovich, Read e Eger (1994), com uma média de 48,4 dias e por Butterworth e Denny (1991) em cães com grau 1 e com uma média de 41 dias de evolução clínica. $O$ fato destes animais terem sinais neurológicos mais brandos, acarreta no tratamento inicial médico e nos casos onde não ocorre resposta favorável, há o encaminhamento para outra modalidade de tratamento, acarretando em tempo de evolução mais longo observados neste estudo e nos outros.

Apesar de ser um estudo clínico com possibilidades de falhas na coleta de informação do proprietário, o tempo de retorno à locomoção é um evento muito esperado e marcante, tanto pelo lado psicológico como prático. Representa um fator menos subjetivo do que outros parâmetros, sendo portanto, confiável em ser analisado (FERREIRA; CORREIA; JAGGY, 2002).

A média obtida no tempo de retorno a locomoção por alguns autores em animais com presença de percepção da dor profunda e submetidos a tratamento cirúrgico foi de 10,8 dias (FERREIRA; CORREIA; JAGGY, 2002), 12,9 dias (DAVIES; BROWN, 2002) e 10,6 dias (YOVICH; READ; EGER, 1994). No presente estudo obteve-se média similar de 10,10 dias para cães com grau 3 e 4 e submetidos a acupuntura. Esta resposta foi significativa e a diminuição em cerca de $50 \%$ do período de reabilitação motora quando comparada ao grupo que não recebeu a acupuntura, cuja média foi de 20,83 dias. Mas quando o resultado de 10,10 dias do grupo com acupuntura é comparado com outro estudo com acupuntura, obteve-se resultados mais precoces do que a média relatada de 17,5 dias (JANSSENS, 1983). Esta diferença em dias é importante, principalmente perante o proprietário do animal, onde uma precocidade de 4 a 5 dias no retorno a locomoção constitui-se em fator relevante (FERREIRA; CORREIA, JAGGY, 2002). 
Segundo Janssens (1983), o retorno à locomoção ocorreu após uma média de 4,8 sessões de acupuntura. No presente estudo encontrou-se uma média de 2,2 sessões para a reabilitação motora.

Padilha e Selmi (1999) encontraram uma média de 20,6 dias para o retorno a locomoção em cães com paraplegia e presença de percepção da dor profunda e submetidos à técnica de fenestração dos discos intervertebrais. Este resultado não diferiu do encontrado no presente estudo, onde os cães com grau 3 e 4 e não submetidos à acupuntura apresentaram uma média de 20,83 dias para a reabilitação motora.

Para quantificar a melhora do estado neurológico realizou-se a comparação das médias dos escores da escala funcional numérica nos diferentes momentos em relação ao grupo com e sem acupuntura.

Quando comparados de forma geral, independente dos graus de lesão, ambos os grupos não tiveram diferença significativa no momento 0 , o que permite concluir que no início do tratamento havia homogeneidade em relação ao estado neurológico entre os mesmos, sendo possível o confronto entre os tratamentos a partir desta fase inicial. Nos momentos 7 e 14 também não se observou diferença significativa entre os grupos, mas ao analisar as médias dos escores totais do grupo com acupuntura, estas foram sempre superiores em relação ao grupo sem acupuntura. Este fato sugere que o estado neurológico após 7 e 14 dias de tratamento, dos animais que receberam acupuntura era melhor do que os que não realizaram acupuntura. No momento final, o grupo de tratamento com acupuntura obteve médias superiores em relação ao grupo sem acupuntura, sendo esta diferença significativa, compatível com a melhora no quadro neurológico.

Além disso, análise isolada dentro de cada grupo, com acupuntura e sem acupuntura, revelou uma diferença significativa entre os momentos quando comparados dois a dois, observada em ambos os grupos. Isto representa que a escala funcional numérica foi eficaz em detectar mudança no estado neurológico destes animais ao longo do tratamento e que ambos os grupos apresentaram evolução neurológica favorável.

Outro estudo descreveu uma escala numérica e verificou que foi de forma significativa mais confiável do que escala análoga visual em cães com discopatia tóraco-lombar aguda, com a finalidade de determinar a taxa e o nível de recuperação funcional (OLBY et al., 2001).

Entretanto, no grupo de cães com grau 1 e 2, tanto no tratamento com acupuntura e sem acupuntura, não se obteve diferença significativa na média dos escores da escala funcional numérica, quando comparados entre eles. Isto indica que o estado neurológico 
destes animais não é grave a ponto de alterar a pontuação da referida escala, devendo-se utilizar outro método para determinar o grau de melhora para comparar os dois grupos.

Para estes animais a melhora foi considerada em relação ao controle da dor, nos casos de grau 1, além da melhora da propriocepção e paraparesia nos casos de grau 2. Os resultados de outros estudos em cães tratados com acupuntura (JANSSENS, 1983; STILL, 1988, 1989) foram similares ao presente estudo, que obteve sucesso de $100 \%$, inclusive no grupo sem acupuntura. Foi detectado um caso de recidiva para o grupo sem acupuntura, cujo proprietário do animal relacionou com o período de cio.

Still (1988) comparou eletroacupuntura ocasional e acupuntura simples em cães com grau 1 e 2 e observou que o número médio de sessões no grupo com eletroacupuntura ocasional variou de 4 a 5 sessões, respectivamente. No presente estudo obteve-se resultados similares com uma média total de 5,2 sessões para animais com grau 1 e 2 , sendo que o retorno a propriocepção, observado no dia de retorno, foi alcançado com uma média de 3,4 sessões.

Nos animais de grau 3 e 4, as médias dos escores funcionais no início do tratamento e no final não demonstraram diferença significativa entre os grupos com acupuntura e sem acupuntura, ou seja, logo no início do tratamento os dois grupos possuíam o mesmo nível de estado neurológico, permitindo a sua comparação, sendo que no final do tratamento, atingiram o mesmo nível de melhora neurológica. Entretanto na $1^{\mathrm{a}}$ e $2^{\mathrm{a}}$ semana de tratamento, o grupo com acupuntura teve melhora significativa no estado neurológico em comparação com o grupo sem acupuntura, compatível com o fato de ter antecipado o retorno à locomoção nestes animais.

Os cães com grau 5 e que receberam acupuntura apresentaram estado neurológico superior e significativo em relação ao grupo sem acupuntura somente no final do tratamento. $\mathrm{Na}$ análise isolada no grupo de animais que receberam acupuntura, houve melhora com o passar do tempo, mas na comparação não foi superior do que o grupo que não recebeu acupuntura, exceto no momento final, onde detectou-se diferença significativa. $\mathrm{O}$ grupo que não recebeu acupuntura teve evolução neurológica lenta, sendo esta estacionada até o final do tratamento, não sendo detectada diferença significante entre os momentos de tratamento. Este fato está relacionado à localização da lesão neurológica nestes cães, onde a perda da percepção da dor profunda implica em alteração em tratos espinhais mais profundos e acarretando em uma recuperação mais lenta e às vezes impossível. 
A recuperação ocorreu em menor grau e de forma mais lenta, porém a acupuntura parece ter melhorado o nível do estado neurológico no momento final dos animais com grau de lesão 5.

Estudos revelam que pequenos grupos de axônios sobreviventes podem ocorrer e promover entrada de estímulos de centros superiores, explicando o fato de alguns animais que não retornaram com a percepção da dor profunda, conseguirem o caminhar espinhal e ainda o retorno voluntário da cauda (SHARP; WHEELER, 2005), o que foi observado em dois animais do grupo com acupuntura no presente estudo.

Janssens (1983) encontrou uma média de 76 dias para o retorno a locomoção em cães sem percepção a dor profunda, ou seja grau 5, submetidos à acupuntura. Entretanto no presente estudo observou-se um retorno mais precoce, com média de 14,66 dias em 50\% (3) dos animais com grau 5 e que receberam acupuntura.

Davies e Sharp (1983) observaram taxa de 7\% de animais com grau 5 e que recuperaram a locomoção com tratamento médico e sem acupuntura. Esta taxa foi inferior a encontrada no presente estudo, onde $12,5 \%$ (1) dos cães com grau 5 e que não receberam acupuntura, retornaram a locomoção.

Cerca de $80,77 \%$ dos cães que receberam acupuntura apresentaram sonolência em pelo menos uma sessão, sendo estes resultados similares aos obtidos em outro estudo (CASSU, 2002) e confirmando o efeito hipnótico ou sedativo da acupuntura descrito em literatura (CARNEIRO, 2001; HONG JIN PAI et al., 2004; SMITH, 1992).

A presença de salivação ou secreção serosa em 30,77\% dos cães tratados com acupuntura revela que nestes animais pode ter ocorrido o estímulo parassimpático, promovendo a secreção glandular, assim como obtido em estudos humanos (DAWIDSON et al., 1998, 1999).

O fato da acupuntura ter demonstrado melhora em cães com lesão medular grave, com sinais de fraqueza a paralisia, obtida em diversos estudos (JANSSENS, 1983, 1985, 1992; SHIMIZU, 2003; STILL, 1988), é difícil avaliar se este benefício ocorreu pela acupuntura ou evolução natural do quadro (JOSEPH; 1992). Portanto, o presente estudo foi importante na comparação entre um grupo com acupuntura e sem acupuntura, a fim de estabelecer o parâmetro da melhora e a sua eficácia.

Outro fator de controvérsia é uso de corticosteróide nestes casos com efeitos adversos na recuperação neurológica em humanos e efeito negativo no tratamento com acupuntura (STILL, 1988). 
A maioria dos animais deste estudo receberam terapia prévia ou concomitante a corticosteróides, tanto no grupo com acupuntura como no grupo sem acupuntura. Os resultados finais do sucesso dos tratamentos mostram efeitos benéficos da integração da acupuntura e corticosteróide, apresentando diferença significativa $(p<0,015)$ em relação ao grupo com corticosteróide e sem acupuntura.

Se formos comparar entre os diferentes graus de lesão, não houve diferença no grau 1 e 2, muito embora em ambos os grupos a taxa de sucesso foi de $100 \%$. Em relação ao grupo com acupuntura, foram tratados animais com um tempo de evolução crônica e não responsiva a outros fármacos utilizados, podendo então ser uma opção de tratamento antes da intervenção cirúrgica.

Os resultados mostrando a taxa de sucesso com relação aos animais de grau 3 e 4, mostrou que a integração da acupuntura com tratamento médico não cirúrgico foi benéfica e superior ao grupo sem acupuntura e tratamento médico $(\mathrm{p}<0,047)$. Mas em relação ao grau 5 não houve diferença entre os grupos ( $p>0,124)$, muito embora o número de animais que se recuperaram com acupuntura (3) foi superior ao grupo sem acupuntura (1).

Este efeito sinérgico de ação acupuntura e corticosteróide também foi encontrado em um estudo experimental de injúria medular em cães (JUNG-WHAN YANG et al., 2003), permitindo o uso concomitante destes dois procedimentos, como ocorre na prática clínica em pequenos animais.

Em relação ao nível de recuperação da micção, propriocepção e locomoção, o grupo com acupuntura apresentou taxas de $80 \%, 92,3 \%$ e $96,14 \%$, respectivamente. Em contrapartida a taxa no grupo sem acupuntura foi de $49,99 \%, 54,16 \%$ e 58,33\% demonstrando que o acréscimo da acupuntura é vantajoso para a recuperação destes animais.

O suprimento arterial e venoso da coluna vertebral é segmentado e atinge a região do forame intervertebral, assoalho do canal vertebral e proximidades de nervos espinhais (SHARP; WHEELER, 2005). Dessa forma, sugere-se que os acupontos próximos da região acometida ou que influenciem o segmento medular afetado, possam promover efeitos na região da extrusão, através do relacionamento com o suprimento sanguíneo e aferentes nervosos da região.

Sob este aspecto, a medula espinhal também é ricamente vascularizada, sendo o suprimento arterial oriundo da artéria espinhal e a drenagem venosa pelas veias intervertebrais na região do forame (SHARP; WHEELER, 2005). Observa-se que principalmente os acupontos do Meridiano da Bexiga têm influência nos vasos espinhais e que possam promover efeitos a nível medular. 
Além dos efeitos locais que a acupuntura pode promover, o estímulo das fibras nervosas aferentes acarreta na liberação de neuropeptídeos importantes não só para o fenômeno inicial isquêmico, como também para o processo de regeneração tecidual.

Portanto, sugere-se que a acupuntura pode trazer efeitos positivos tanto nas primeiras 24 horas da injúria, no caso das extrusões, como para o início do processo de regeneração tecidual.

Embora o mecanismo de ação da acupuntura na discopatia intervertebral não está bem esclarecido, a boa recuperação nos animais do presente estudo parece estar relacionado ao fato de que a acupuntura pode ativar regeneração axonal na medula espinhal.

Seus efeitos podem estar relacionados a liberação de neuropeptídeos promotores de regeneração tecidual, como CGRP (DAWIDSON et al., 1998, 1999), e modulação neuroendócrina, com os indícios de liberação de diversos hormônios e fatores liberadores (PULLAN et al., 1983; SHEN MEIHONG et al., 1999), com possíveis efeitos neurotróficos, como o fator liberador de tirotropina (OLBY, 1999).

Mas o foco principal da acupuntura e da MTC é atingir a homeostase ou autoregulação. Tanto o aumento ou a diminuição de uma atividade, seja de um fenômeno fisiológico como patológico, tendem a se normalizar com o estímulo da acupuntura. Pode-se interpretar como uma regulação do sistema simpático e parassimpático. Esta resposta corresponde ao efeito principal de proporcionar um equilíbrio interno, desde que as lesões sejam reversíveis.

O fato das raças condrodistróficas serem predispostas a doença degenerativa do disco intervertebral, corresponde na MTC como um declínio da energia ancestral, ou seja, recebida pelos pais. Esta metáfora pode ser interpretada na linguagem ocidental como a carga genética. Esta predisposição também é justificada pela MTC, onde estes indivíduos estariam mais susceptíveis a fatores externos, como períodos de estações climáticas de frio e umidade, ou movimentos físicos ou exercícios repetitivos, como saltos, pulos. Estes fatores podem causar a extrusão e quadros de dor. Na interpretação da MTC corresponde a um bloqueio da energia no Meridiano envolvido. O princípio de tratamento é representado primariamente em normalizar o fluxo desta energia, desobstruindo o Meridiano, além de fortalecer a resistência do indivíduo a fatores exteriores, e mudanças no hábito de vida. Há necessidade de limitações de determinados movimentos ou exercícios, além de se evitar a obesidade.

Uma vez realizado o diagnóstico da afecção, devem ser propostas ao proprietário do animal todas as possíveis opções de tratamento, levando-se em conta as vantagens e desvantagens de cada uma. Muitas vezes, em alguns pacientes que apresentem efeitos 
adversos a diferentes fármacos ou quando a patologia não responde à terapia convencional, a acupuntura é utilizada de forma integrativa (ALTMAN, 1992).

Animais com discopatia tóraco-lombar que perderam a capacidade de locomoção ou com ausência da percepção da dor profunda por mais de 48 horas, associados ou não a alterações sistêmicas ou restrições financeiras dos proprietários, impedindo o método cirúrgico de tratamento, podem ser abordados por tratamento médico.

A escolha do tipo de tratamento depende de vários fatores, mas qualquer opção que se tome, deve ser instituída o quanto antes. No caso de lesões agudas com menos de 24 horas, em qualquer caso, deve incluir sempre o tratamento medicamentoso, com intuito de impedir os processos decorrentes da concussão medular.

A acupuntura tem sido integrada a este tratamento e devido a uma maior informação dos clientes sobre as técnicas médicas disponíveis e um aumento da expectativa em relação aos tratamentos de seus animais de estimação (ALTMAN, 1992), há uma tendência de aumento da solicitação desta modalidade terapêutica, já considerada como especialidade da área médica e veterinária. 


\section{CONCLUSÕES}

A análise dos resultados obtidos neste estudo permitiu concluir que:

1. A associação do tratamento da acupuntura ao tratamento médico em cães com discopatia tóraco-lombar com grau de lesão 3 e 4 antecipou a melhora do estado neurológico e o retorno à locomoção.

2. A associação do tratamento da acupuntura ao tratamento médico em cães com discopatia tóraco-lombar com grau de lesão 1 e 2 apresentou o mesmo efeito benéfico quando comparado ao tratamento médico isolado.

3. A acupuntura proporcionou uma melhor recuperação dos animais quanto à micção e à propriocepção, quando comparado ao grupo que não foi tratado com a acupuntura. 


\section{REFERÊNCIAS}

ALTMAN, S. Acupuncture therapy in small animal practice. Compendium on Continuing Education for the Practicing Veterinarian. v. 19, n. 11, p. 1238-1244, 1997.

ALTMAN, S. Terapia pela Acupuntura na clínica de pequenos animais. In: ETTINGER, S. J. Tratado de medicina interna veterinária. São Paulo: Manole, 1992. v. 1, p. 507-522.

ANGELI, A. L.; JOAQUIM, J. G. F.; GAMA, E. D.; LUNA, S. P. L. Outcome of 119 dogs and cats treated at the acupuncture unit of the Faculty of Veterinary Medicine and Animal Science of the University of São Paulo State, Botucatu City, Brazil. In: ANNUAL INTERNATIONAL CONGRESS ON VETERINARY ACUPUNCTURE, 29., 2003, Santos. Proceedings...Santos: International Veterinary Acupuncture Society, 2003. p. 337-345.

ARRUDA, B. F.; CARVALHO, A. L. Registro de Título de Especialista em áreas da Medicina Veterinária. Revista Conselho Federal de Medicina Veterinária. v. 9, n. 30, p. 10-12, 2003

BAKHTIARI, J.; SHARIFI, D.; MARJANMEHR, H.; ZARINMEHR, M. Evaluation of the effect of Acupuncture therapy in treatment of muscle injuries in dog. In: ANNUAL INTERNATIONAL CONGRESS ON VETERINARY ACUPUNCTURE, 29., 2003, Santos. Proceedings...Santos: International Veterinary Acupuncture Society, 2003. p. 183-184.

BONTA, I. L. Acupuncture beyond the endorphin concept? Medical Hypotheses, v. 58, n. 3, p. 221-224, 2002.

BRAUND, K. G. Clinical syndromes in veterinary neurology. U.S.A: Willianms e Wilkins, $1986,257 \mathrm{p}$.

BRAY, J. P.; BURBIDGE, H. M. The canine intervertebral disk. Part one: Structure and function. Journal of the American Animal Hospital Association, v. 34, n. 1, p. 55-63, 1998.

CARNEIRO, N. M. Fundamentos da acupuntura médica. Florianópolis: Sistema, 2001, $728 \mathrm{p}$.

CASSU, R. N.Avaliação dos efeitos cardiorrespiratório, endócrino e analgésico da eletroacupuntura em cães. 2002. 197 f. Tese (Doutorado em Anestesiologia) - Faculdade de Medicina, Universidade Estadual Paulista, Botucatu, 2002. 
CASSU, R. N.; LUNA, S. P. L.; CLARK, R. M. O.Eletroacupuncture analgesia in dogs: Is there a difference between uni or bilateral stimulation? In: ANNUAL INTERNATIONAL CONGRESS ON VETERINARY ACUPUNCTURE, 29., 2003, Santos. Proceedings... Santos: International Veterinary Acupuncture Society, 2003. p. 121-136.

CHRISMAN, C.; MARIANI, C.; PLATT, S.; CLEMMS, R. Neurologia para o clínico de pequenos animais. São Paulo: Roca, 2005. 336 p.

COATES, J. R. Intervertebral disk disease. Veterinary Clinics of North América, v. 31, n. 1, p. 77-110, 2000.

COATES, J. R.; SORJONEN, D. C.; SIMPSON, S.; COX, N. C.; WRIGHT, J. C.; HUDSON, J.; FINN-BODNER, S. T.; BROWN, S. A. Clinicopathologic effects of a 21-aminosteroid compound (U74389G) and high-dose methylprednisolone on spinal cord function after simulated spinal cord trauma. Veterinary Surgery, v. 24, n. 2, p. 128-139, 1995.

COLE, E. F. Avaliação dos efeitos terapêuticos obtidos com a alopatia e a acupuntura no tratamento de distúrbios neurológicos decorrentes da cinomose canina. 1996. $205 \mathrm{f}$. Dissertação (Mestrado)- Universidade Federal Rural de Pernambuco, Recife, 1996.

COUGHLAN, A. R. Secondary injury mechanisms in acute spinal cord trauma. Journal of Small Animal Practice, v. 34, n. 3, p. 117- 122, 1993.

DAVIES, J. V.; SHARP, N. J. H. A comparison of conservative treatment and fenestration for thoracolumbar intervertebral disease in the dog. Journal of Small Animal Practice, v. 24, n. 12, p. 721-729, 1983.

DAWIDSON, I.; ANGMAR-MANSON, B.; BLOM, M.; THEODORSSON, E.; LUNDEBERG, T.Sensory stimulation (acupuncture) increases the release of calcitonin generelated peptide in the saliva of xerostomia sufferers. Neuropeptides, v. 33, n. 3, p. 244-250, 1999.

DAWIDSON, I.; ANGMAR-MANSON, B.; BLOM, M.; THEODORSSON, E.; LUNDENBERG, T. Sensory stimulation (acupuncture) increases the release of vasoative intestinal polypeptide in the saliva of xerostomia sufferers. Neuropeptides, v. 32, n. 6, p. 543$548,1998$.

DRAEHMPAEHL, D.; ZOHMANN, A. Acupuntura no cão e no gato. Princípios básicos e prática científica. São Paulo: Roca, 1994. 245 p.

DUVAL, J.; DEWEY, C.; ROBERTS, R.; ARON, D. Spinal cord swelling as a myelographic indicator of prognosis: a retrospective study in dogs with intervertebral disc disease and loss of deep pain perception. Veterinary Surgery, v. 25, n. 1, p. 6-12, 1996. 
FERREIRA, A. J. A.; CORREIA, J. H. D.; JAGGY, A. Thoracolumbar disc disease in 71 paraplegic dogs: influence of rate of onset and duration of clinical signs on treatment results. Journal of Small Animal Practice, v. 43, n. 4, p. 158-163, 2002.

GADULA, E. Acupuncture in paraplegia. Disponível em:

$<$ http://users.med.auth.gr/ karanik/english/articles/icmart99/ab9.htm>. Acesso em: 05 fev. 2004.

GAVIOLLE, M. C. Modelo experimental para o estudo da interação entre acupuntura e o fenômeno regenerativo induzido em caudas de girinos de Rana catesbiana (SHAW, 1802). 1999. 105 f. Tese (Doutorado em Patologia Experimental e Comparada) - Faculdade de Medicina Veterinária e Zootecnia, Universidade de São Paulo, São Paulo, 1999.

GUYTON, A. C. Tratado de fisiologia médica. Rio de Janeiro: Interamericana, 1984, 926 p.

HAYASHI, A. M.; CARREIRA, C. C. Acupuntura e reabilitação locomotora na cinomose canina - relato de caso. In: CONGRESSO PAULISTA DE CLÍNICOS DE VETERINÁRIOS DE PEQUENOS ANIMAIS, 4., 2004, São Paulo. Anais... São Paulo: Associação Nacional de Clínicos de Pequenos Animais de São Paulo, 2004. p. 105.

HAYASHI, A. M.; MATERA, J. M. ; SOARES, T. S.; PINTO, A. C. B. C. F. Acupuntura e medicina herbal chinesa no tratamento de compressão extra-dural cervical: relato de caso em cão. In: CONGRESSO PAULISTA DE CLÍNICOS VETERINÁRIOS DE PEQUENOS ANIMAIS, 5, 2005, São Paulo. Anais... São Paulo: Associação Nacional de Clínicos de Pequenos Animais de São Paulo, 2005. p.181.

HAYASHI, A. M.; SHIGUIHARA, C. A.; TORRO, C. A. Acupuntura e fitoterapia chinesa como medicina complementar em alterações locomotoras em cães. Relato de 3 casos.

Brazilian Journal Veterinary Research And Animal Science, v. 40, p. 200, 2003.

Suplement.

HONG JIN PAI, H. J.; VALLE, L. B. S.; BABÁ, C. R.; PORTIOLLI, C. Y.; SUDA, E.;HOSSOMU, J.; ARACAVA, M.; YAMAMOTO, R.; ABRAMAVICUS, S.; LESSA, S. M. R.; MARIOTTO, T. R. Mecanismos analgésicos da acupuntura. Disponível em : $<$ http:// www.smba.org.br/artigos_mecanismos.htm>. Acesso em: 12 mar. 2004.

HUKKANEN, M.; KONTTINEN, Y. T.; SANTAVIRTA, S.; PAAVOLAINEN, P.; GU, X. H.; TERENGHI, G.; POLAK, J. M. Rapid proliferation of calcitonin gene-related peptideimmunoreactive nerves during healing of rat tibial fracture suggests neural involvement in bone growth and remodelling. Neuroscience. v. 54, n. 4, p. 969-979, 1993.

JAGGAR, D. History and basic introduction to veterinary acupuncture. Problems in Veterinary Medicine, v. 4, n. 1, p. 1-11, 1992. 
JANSSENS, L. A. A. Acupuncture treatment for canine thoracolumbar disk protusions. A review of 78 cases. Veterinary Medicine Small Animal Clinician, v. 78, n. 10, p. 1580$1585,1983$.

JANSSENS, L. A. A.Acupuncture for the treatment of thoracolumbar and cervical disc disease in the dog. Problems in Veterinary Medicine, v. 4, n. 1, p. 107-116, 1992.

JANSSENS, L. A. A. Mechanical and pathophysiological aspects of acute spinal cord trauma. Journal of Small Animal Practice, v. 32, n. 11, p. 572-578, 1991.

JANSSENS, L. A. A. Observations on acupuncture therapy of chronic osteoarthritis in dogs: a review of sixty-one cases. Journal Small Animal Practice, v. 27, n. 12, p. 825-837, 1986.

JANSSENS, L. A. A.The treatment of canine cervical disc disease by acupuncture: a review of thirty two cases. Journal Small Animal Practice, v. 26, n. 4, p. 203-212, 1985.

JEN-CHUEN HSIEH; CHUNG-HAOW TU; FANG-PEY CHEN; MIN-CHI CHEN; TZUCHEN YEH; HUI-CHENG CHENG; YU-TE WU; REN-SHYAN LIU; LOW-TONE HO. Activation of the hypothalamus characterizes the acupuncture stimulation at the analgesic point in human: a positron emission tomography study. Neuroscience Letters, v. 307, n. 2, p. 105-108, 2001.

JEN-HSOU LIN; PANZER, R. Acupuncture for reprodutive disorders. Problems in Veterinary Medicine, v. 4, n. 1, p. 155-161, 1992.

JEN-HWEY CHIU; MAO-SHU CHUNG; HUI-CHENG CHENG; TZU-CHENG YEH; JENCHUEN HSIEH; CHUNG-YEN CHANG; WAN-YO KUO; HENRICH CHENG; LOWTONE HO. Different central manifestations in response to electroacupuncture at analgesic and nonanalgesic acupoints in rats: a manganese-enhanced functional magnetic resonance imaging study. Canine Journal Veterinary Research, v. 67, n. 2, p. 94-101, 2003.

JEOUNG-WOO KANG; TAE-WAN KIM; JUN-HO LA; TAE-SIK SUNG; HYUN-JU KIM; YOUNG-BAE KWON; JEUM-YONG KIM; IL-SUK YANG. Electroacupuncture ameliorates experimental colitis induced by acetic acid in rat. Journal of Veterinary Science, v. 5, n. 3, p. 189-195, 2004.

JERRAM, R. M.; DEWEY, C. W. Acute thoracolumbar disk extrusion in dogs - Part I. Compendium on Continuing Education for the Practice Veterinary, v. 21, n. 10, p. $922-$ 930, 1999a.

JERRAM, R. M.; DEWEY, C. W. Acute thoracolumbar disk extrusion in dogs - Part II. Compendium on Continuing Education for the Practice Veterinary, v. 21, n. 11, p. 10371047, $1999 \mathrm{~b}$. 
JI-SHENG HAN. Acupuncture and endorphins. Neuroscience Letters, v. 361, n. 3, p. 258 $261,2004$.

JOAQUIM, J. G. F Acupuntura e motilidade gastrointestinal. In: WORLD CONGRESS OF INTEGRATED MEDICAL ACUPUNCTURE - ICMART; CONGRESSO MÉDICO BRASILEIRO DE MEDICINA CHINESA - ACUPUNTURA DA AMBA, 9., 2003, Guarujá. Anais... Guarujá: Associação Brasileira de Acupuntura Veterinária, 2003. p. 52-58.

JOAQUIM, J. G. F.; LUNA, S. P. L.; TORELLI, S.; ANGELI, A. L.; GAMA, E. D. Study of 43 dogs with neurological disease: A Western and Eastern View of the Neurological Pattern of diseases. In: ANNUAL INTERNATIONAL CONGRESS ON VETERINARY ACUPUNCTURE, 29., 2003, Santos. Proceedings... Santos: International Veterinary Acupuncture Society, 2003. p. 289-300.

JOSEPH, R. Neurologic evaluation and its relation to acupuncture. Acupuncture for neurologic disorders. Problems in Veterinary Medicine, v. 4, n. 1, p. 98-106, 1992.

JUNG-WHAN YANG; SEONG-MOK JEONG; KANG-MOON SEO; TCHI-CHOU NAM. Effects of corticosteroid and electroacupuncture on experimental spinal cord injury in dogs. Journal of Veterinary Science, v. 4, n. 1, p. 97 - 101, 2003.

KAWAKITA, K.; GOTOH, K. Role of polymodal receptors in the acupuncture-mediated endogenous pain inhibitory systems. Progress in Brain Research, v. 113, p. 507-523, 1996.

KIRSCH, D. L.; LERNER, F. N. Eletromedicine.The textbook of the american academy of pain management. The Web-Journal of Acupuncture. Disponível em: $<$ http://users.med.auth.gr/ karanik/english/electro.htm>. Acesso em 01 mar. 2004.

KLIDE, A. M.; KUNG, S. H. Veterinary Acupuncture. Pennsylvania: University of Pennsylvania Press, 1977, 297 p.

KONTTINEN, Y. T.; IMAI, S.; SUDA, A. Neuropeptides and the puzzle of bone remodeling. state of the art. Acta Orthopaedica Scandinavica, v. 67, n. 6, p. 632-639, 1996.

LANGEVIN, H. M.; CHURCHILL, D. L.; CIPOLLA, M. J. Mechanical signaling through connective tissue: a mechanism for the therapeutic effect of acupuncture. FASEB Journal, v.15, n. 12, p. 2275-2282, 2001.

LECOUTEUR, R. A.; CHILD, G. Moléstias da medula espinhal. In: ETTINGER, S. J. Tratado de medicina interna veterinária. São Paulo: Manole, 1992. v. 2, p.655-736.

LI DING. Acupuntura, teoria do Meridiano e pontos de acupuntura. São Paulo: Roca, 1996, $461 \mathrm{p}$. 
LIANFANG HE .Involvement of endogenous opioid peptides in acupuncture analgesia. Pain, v. 31, p. 99-121, 1987.

LIPPINCOTT, C. L. Hemilaminectomy in dogs without deep pain perception. California Veterinary, v. 45, n. 5, p. 24-28, 1991.

LOONEY, A. L. Using acupuncture in veterinary practice. Veterinary Medicine. v. 95, n. 8, p. 615-619, 2000.

LÓPEZ, H. S.; BUENDIA, G. L. Acupuntura veterinária. México: Nueva Editorial Interamericana, 1990, $346 \mathrm{p}$.

LOW, J.; REED, A. Eletroterapia explicada: princípios e prática. 3. ed. São Paulo: Manole, 2001. $472 \mathrm{p}$.

LUNA, S. P. L. Emprego da acupuntura em anestesia. In: FANTONI, D.T.; CORTOPASSI, S.R.G. Anestesia em cães e gatos. São Paulo: Roca, 2002. 389 p.

MACIOCIA, G. Os fundamentos da medicina chinesa. Um texto abrangente para acupunturistas e fitoterapeutas. São Paulo: Roca, 1996. 658 p.

MAYER, D. J. Biological mechanisms of acupuncture. Progress in Brain Research, v. 122, p. 457-477, 2000.

MAYHEW, P. D.; MCLEAR, R. C.; ZIEMER, L. S.; CULP, W. T. N.; RUSSELL, K. N.; SHOFER, F. S.; KAPATKIN, A. S.; SMITH, G. K. Risk factors for recurrence of clinical signs associated with thoracolumbar intervertebral disk herniation in dogs: 229 cases (19942000). Journal of the American Veterinary Medical Association, v. 225, n. 8, p. 12311236, 2004.

MC DONNELL, J. J.; PLATT, S. R.; CLAYTON, L. A. Neurologic conditions causing lameness in companion animals. Veterinary Clinics of North America. Small Animal Practice, v. 31, n. 1, p. 17-38, 2001.

MINCHEOL CHOI; JUHYUN JUNG; MINHO SEO; KICHANG LEE; TCHICHOU NAM; ILSUK YANG; YEOSUNG YOON; JUNGHEE YOON. Ultrasonographic observation of intestinal mobility of dogs after acupunctural stimulation on acupoints ST36 and BL-27. Journal of Veterinary Science, v. 2, n. 3, p. 221-226, 2001.

NECAS, A. Clinical aspects of surgical treatment of thoracolumbar disc disease in dogs. A retrospective study of 300 cases. Acta Veterinary Brno, v. 68, p. 121-130, 1999.

NORMAN, G. R.; STREINER, D. L. Biostatistics. The bare essentials. 2. ed. Canada: B.C. Decker Inc., 2000, 324 p. 
OLBY, N. Current concepts in the management of acute spinal cord injury. Journal of Veterinary Internal Medicine, v. 13, n. 5, p. 399-407, 1999.

OLBY, N. J.; DE RISIO, L.; MUNANA, K. R.; WOSAR, M. A.; SKEEN, T. M.; SHARP, N. J. H.; KEENE, B. W. Development of a functional scoring system in dogs with acute spinal cord injuries. American Journal of Veterinary Research, v. 62, n. 10, p. 1624-1628, 2001.

OLBY, N. J.; DYCE, J.; HOULTON, J. E. F. Correlation of plain radiographic and lumbar myelographic findings with surgical findings in thoracolumbar disc disease. Journal of Small Animal Practice, v. 35, n. 7, p. 345-350, 1994.

OLBY, N. J.; LEVINE, J.; HARRIS, T.; MUNANA, K.; SKEEN, T.; SHARP, N. Long term functional outcome of dogs with severe injuries of the thoracolumbar spinal cord: 87 cases (1996-2001). Journal of the American Veterinary Medical Association, v. 222, n. 6, p. 762-769, 2003.

OLBY, N. J.; MUÑANA, K. R.; SHARP, N. J.; THRALL, D. E. The computed tomographic appearance of acute thoracolumbar intervertebral disc herniations in dogs. Veterinary Radiology, v. 41, n. 5, p. 396-402, 2000.

PADILHA FILHO, J. G.; SELMI, A. L. Retrospective study of thoracolumbar ventral fenestration through intercostal thoracotomy and paracostal laparatomy in the dog. Brazilian Journal of Veterinary Research and Animal Science, v. 36, n. 4, p. 223-227, 1999.

PULLAN, P. T.; FINCH, P. M.; YUEN, R. W. M.; WATSON, F. E. Endogenous opiates modulate release of growth hormone in response to electroacupuncture. Life Science, v. 32, n. 15, p. 1705-1709, 1983.

ROGERS, P. A. M.; SCHOEN, A. M.; LIMEHOUSE, J. Acupuncture for immune-mediated disorders. Problems in Veterinary Medicine, v. 4, n. 1, p. 162-193, 1992.

ROSS, J. Combinações dos pontos de acupuntura. A chave para o êxito clínico. São Paulo: Roca, 2003. 490 p.

SÁNCHEZ-ARAÚJO, M.; PUCHI, A. Acupuncture enhances the efficacy of antibiotics treatment for canine otitis crises. Acupuncture \& Electro-therapeutics Research, v. 22, n. 4, p.191-206, 1997.

SANDE, R. D. Radiography, myielography, computed tomography, and magnetic resonance imaging of the spine. Veterinary Clinics of North America: Small Animal Practice, v. 22, n. 4, p. 811-831, 1992.

SCHOEN, A. M. Veterinary acupuncture, ancient art to modern medicine. St. Louis: Mosby, 1994. $707 \mathrm{p}$. 
SCOGNAMILLO-SZABÓ, M. V. R. Efeito da acupuntura sobre a reação inflamatória imune induzida pelo carrapato Rhipicephalus sanguineus (Latreille, 1806) em cobaias e cães. 1999. 119 f. Dissertação (Mestrado em Patologia Animal) - Faculdade de Ciências Agrárias e Veterinárias, Universidade de São Paulo, Jaboticabal, 1999.

SCOGNAMILLO-SZABÓ, M. V. R.; BECHARA, G. H. Acupuntura: bases científicas e aplicações. Ciência Rural, Santa Maria, v. 31, n. 6, p. 1091-1099, 2001.

SCOTT, H. W.; McKEE, W. M. Laminectomy for 34 dogs with thoracolumbar intervertebral disc disease and loss of deep pain perception. Journal of Small Animal Practice, v. 40, n. 9 , p. 417-422, 1999.

SHARIFI, D.; BAKHTIARI, J. Histomorphologycal evaluation of acupuncture therapy on radial fracture healing in dog. Journal of Faculty of Veterinary Medicine, University of Tehran, v. 58, n. 1, p.73-77, 2003.

SHARIFI, D.; BAKHTIARI, J.; SASSANI, F.; REZAEI, T. Evaluation of the effect of acupuncture therapy on repair of the achills tendon (Tendo Calcaneus) in dog. In:

INTERNATIONAL CONGRESS ON VETERINARY ACUPUNCTURE, 29., 2003, Santos. Proceedings... Santos: International Veterinary Acupuncture Society, 2003. p. 185-186.

SHEN MEIHONG; QI XIAOHUA; HUANG YE; LÜ YUE. Effects of acupuncture on the pituitary-thyroid axis in rabbits with fracture. Journal of Traditional Chinese Medicine, $v$. 19, n. 4, p. 300-303, 1999.

SHI PING ZHANG; JIN SHAN ZHANG; KEN K. L. YUNG; HONG QI ZHANG. Nonopioid-dependent anti-inflammatory effects of low frequency electroacupuncture. Brain Research Bulletin, v. 62, n. 4, p. 327-334, 2004.

SHIMIZU, E. Eletroacupuncture treatment of acute thoracolumbar disk disease type I grade 4 $\mathrm{C}$ in condrodistrophic dogs not treated with surgery. In: INTERNATIONAL CONGRESS ON VETERINARY ACUPUNCTURE, 29., 2003, Santos. Proceedings... Santos: International Veterinary Acupuncture Society, 2003. p. 407-413.

SHORES, A.; ROUDEBUSH, P. Ataxia, paresia e paralisia. In: ETTINGER, S. J., Tratado de medicina interna veterinária. São Paulo: Manole, 1992. v. 1, p. 61-64.

SIENDENTOPF, C. M.; GOLASZEWSKI, S. M.; MOTTAGHY, F. M; RUFF, C. C.; FELBER, S.; SCHLAGER, A. Functional magnetic resonance imaging detects activation of the visual association cortex during laser acupuncture of the foot in humans. Neuroscience Letters, v. 327, n. 1, p. 53-5, 2002.

SMITH, F. W. K. Neurophysiologic basis of acupuncture. Problems in Veterinary Medicine, v. 4, n. 1, p. 34-52, 1992. 
SMITH, J. D.; NEWELL, S. M.; BUDSBERG, S. C.; BENNETT, R. A. Incidence of contralateral versus ipsilateral neurological signs associated with lateralised Hansen type I disc extrusion. Journal of Small Animal Practice, v. 38, n. 11, p. 495-497, 1997.

STANDARD international acupuncture nomenclature: memorandum from a WHO meeting. Bulletin of World Health Organization, v. 68, n. 2, p. 165-169, 1990.

STENER-VICTORIN, E.; LUNDEBERG, T.; WALDENSTRÖM, U.; BILEVICIUTELJUNGAR, I.; JANSON, P. O. Effects of electro-acupuncture on corticotropin-releasing factor in rats with experimentally-induced polycystic ovaries. Neuropeptides, v. 35, n. 5, p. 227-231, 2001.

STILL, J. Acupuncture treatment of thoracolumbar disc disease: a study of 35 cases. Companion Animal Practice, v. 2, n. 1, p. 19-24, 1988.

STILL, J. Analgesic effects of acupuncture in thoracolumbar disc disease in dogs. Journal of Small Animal Practice, v. 30, n. 5, p. 298-301, 1989.

STILL, J. Muscle paresis and paralysis. In: INTERNATIONAL CONGRESS ON VETERINARY ACUPUNCTURE, 29., 2003, Santos. Proceedings... Santos: International Veterinary Acupuncture Society, 2003. p. 69-72.

TOOMBS, J. P. Cervical intervertebral disk disease in dogs. Continuing Education for the Practicing Veterinarian, v. 14, n. 11, p. 1477-1489, 1992.

TORRO, C. A. Atlas prático de acupuntura no cão. São Paulo: Varela, 1997. 186 p.

WYNN, S.G.; MARSDEN, S. Manual of natural veterinary medicine science and tradition. Missouri: Mosby, 2003. 740 p.

YAMAMURA, Y. Acupuntura tradicional. A arte de inserir. 2. ed. São Paulo: Roca, 2001. $919 \mathrm{p}$.

YAMAMURA, Y. Efeitos da acupuntura evidenciados por estudos clínicos e experimentais controlados e realizados na Universidade Federal de São Paulo, Escola Paulista de Medicina, no período de 1992 a 2002. 2002. $81 \mathrm{f}$. Tese (Livre-Docência em Ortopedia e Traumatologia) - Faculdade de Medicina, Universidade Federal de São Paulo, São Paulo, 2002.

YAMAMURA, Y.; FILHO, J. L.; NOVO, N. F.; PUERTAS, E. B.; VASCONCELOS, L. P. W. G. Tratamento da hérnia do disco intervertebral lombar pela acupuntura. Revista Brasileira de Acupuntura, v. 2, n. 1, p. 13-24, 1996. 
YAMAMURA, Y.; MELLO, L. E. A. M.; NOVO, N. F.; GUIMARÃES, C. M.; TABOSA, A. M. F. Aspectos elétricos das agulhas de acupuntura. Revista Paulista de Acupuntura, v. 2, n. 1, p. 2-6, 1996.

YAMAMURA, Y.; MELLO, L. E. A. M; TABOSA, A. M. F.; CRICENTI, S. V.; DIDIO, L. J. A. Acupuncture: phisiologic effects explained on a neuroanatomical and neurophysiological basis. Revista Paulista de Acupuntura, v. 3, n. 1, p. 14-18, 1997.

YANN-CHING HWANG. Anatomy and classification of acupoints. Problems in Veterinary Medicine, v. 4, n. 1, p. 12-15, 1992.

YOVICH, J. C.; READ, R.; EGER, C. Modified lateral spinal decompression in 61 dogs with thoracolumbar disc protusion. Journal of Small Animal Practice, v. 35, n. 7, p. 351-356, 1994. 
APÊNDICE A

\begin{tabular}{|c|c|c|c|c|c|c|}
\hline Cão no & $\begin{array}{c}\text { Prontuário } \\
\text { HOVET }\end{array}$ & Raça & Sexo & $\begin{array}{l}\text { Idade } \\
\text { (anos) }\end{array}$ & $\begin{array}{l}\text { Peso } \\
\text { (kg) }\end{array}$ & Lesão \\
\hline 1 & 160121 & Dachshund & Fêmea & 5 & 9,9 & L2-3 \\
\hline 2 & 160034 & Dachshund & Fêmea & 7 & 6,8 & L1-2 \\
\hline 3 & 166928 & Dachshund & Macho & 6 & 8,5 & T13-L1 \\
\hline 4 & 148504 & Dachshund & Fêmea & 7 & 5 & L1-2; L4-5; L5-6 \\
\hline 5 & 159571 & Dachshund & Fêmea & 5 & 6 & T11-12 \\
\hline 6 & 162316 & Cocker spaniel & Fêmea & 5 & 12,3 & T9-10; T10-11; L2-3 \\
\hline 7 & 134180 & Springer spaniel & Macho & 7 & 20,4 & T13-L1 \\
\hline 8 & 165056 & Dachshund & Macho & 7 & 7,7 & T9-10; T11-12 a T13-L1 \\
\hline 9 & 150560 & Dachshund & Macho & 7 & 9,5 & T10-11;T12-13 a L2-3 \\
\hline 10 & 168467 & Dachshund & Fêmea & 3 & 7,2 & T11-12 extrusão \\
\hline 11 & 162818 & Dachshund & Fêmea & 4 & 7,4 & T13-L1 \\
\hline 12 & 161342 & Dachshund & Macho & 5 & 9,5 & T13-L1; T12-13 \\
\hline 13 & 161146 & Poodle & Macho & 7 & 8,2 & sem lesão radiográfica \\
\hline 14 & 167087 & Dachshund & Fêmea & 5 & 6,8 & L1-2 \\
\hline 15 & 162644 & Dachshund & Fêmea & 6 & 6 & T10-11; T11-12; T12-13 \\
\hline 16 & 163361 & Dachshund & Fêmea & 4 & 8 & $\mathrm{~T} 12-13$ \\
\hline 17 & 161145 & Dachshund & Fêmea & 6 & 8,2 & $\mathrm{~T} 11-12$ \\
\hline 18 & 162847 & Dachshund & Macho & 6 & 9,3 & T12-13 \\
\hline 19 & 161070 & Dachshund & Macho & 7 & 5,6 & T11-12; L4-5; L5-6 \\
\hline 20 & 167652 & Poodle & Fêmea & 1,7 & 2,5 & T13-L1; T10-11; T12-13 \\
\hline 21 & 166754 & Dachshund & Macho & 6,16 & 10,4 & T11-12; L2-3 \\
\hline 22 & 167664 & Dachshund & Macho & 7 & 6,6 & $\mathrm{~T} 12-13$ \\
\hline 23 & 167638 & Dachshund & Macho & 6,4 & 8,5 & $\mathrm{~T} 11-12$ \\
\hline 24 & 93438 & Dachshund & Macho & 12 & 12 & - \\
\hline 25 & 169567 & SRD & Macho & 12 & 11,5 & L2-3 e discreto L4-5 \\
\hline 26 & 167330 & Dachshund & Fêmea & 6 & 7,9 & T10-11; T11-12; T12-13 \\
\hline 27 & 166950 & Dachshund & Fêmea & 7 & 9,5 & - \\
\hline 28 & 161063 & Dachshund & Fêmea & 7 & 5,6 & T12-13 \\
\hline 29 & 162838 & SRD & Fêmea & 10 & 24 & T13-L1 \\
\hline 30 & 162776 & Dachshund & Fêmea & 4 & 7,7 & T12-13; T11-12; T10-11 \\
\hline 31 & 157935 & Dachshund & Fêmea & 6 & 7,7 & T11-12; T12-13 \\
\hline 32 & 108653 & Poodle & Fêmea & 7 & 7,1 & T11-12 \\
\hline 33 & 142422 & Dachshund & Fêmea & 9 & 8,6 & T10-11; T11-12; T12-13 \\
\hline 34 & 169112 & Dachshund & Macho & 8 & 8,1 & T10-11; T11-12; L3-4 \\
\hline 35 & 170320 & Dachshund & Macho & 4 & 3 & T12-13; T13-L1; L3-4; L5-6; \\
\hline 36 & 166358 & Poodle & Fêmea & 4 & 4,2 & T11-12; T12-13 \\
\hline 37 & 167352 & Cocker spaniel & Fêmea & 4 & 15,3 & T11-12; T12-13 \\
\hline 38 & 163429 & Dachshund & Fêmea & 2 & 5,5 & $\mathrm{~T} 10-11$ \\
\hline 39 & 163094 & Dachshund & Macho & 5 & 10 & T11-12 \\
\hline 40 & 163462 & Dachshund & Macho & 5 & 16,8 & $\mathrm{~T} 11-12$ \\
\hline
\end{tabular}

Quadro 1 - Número do animal, número de identificação no Hospital Veterinário, raça, sexo, idade (em anos), peso (em quilogramas) e local da lesão detectadas por imagens radiográficas dos cães atendidos durante o estudo (1 a 40) - FMVZ/USP - São Paulo, 2006 
APÊNDICE B

\begin{tabular}{|c|c|c|c|c|c|c|}
\hline Cão $\mathbf{n}^{\mathbf{0}}$ & $\begin{array}{c}\text { Prontuário } \\
\text { HOVET }\end{array}$ & Raça & Sexo & $\begin{array}{c}\text { Idade } \\
\text { (anos) }\end{array}$ & Peso (kg) & Lesão \\
\hline 41 & 163148 & Dachshund & Macho & 4 & 7,7 & T11-12 \\
42 & 165012 & Pequinês & Macho & 5 & 5,4 & T11-12 \\
43 & 166227 & Dachshund & Fêmea & 7 & 8 & - \\
44 & 164095 & Dachshund & Macho & 7 & 10,4 & - \\
45 & 166584 & Cocker spaniel & Macho & 5 & 19,5 & T12-13 \\
46 & 165849 & Dachshund & Macho & 4 & 9,1 & T11-12; T12-13 \\
47 & 165314 & Dachshund & Macho & 5 & 10,2 & L2-3 \\
48 & 164402 & Dachshund & Fêmea & 6 & 6,8 & T11-12 Extrusão ventral \\
$49^{1}$ & 163068 & Dachshund & Fêmea & 5 & 8,3 & T13-L1 Extrusão à esquerda \\
$50^{*}$ & 164159 & Dachshund & Fêmea & 4 & 6,3 & T13-L1 Extrusão à direita \\
$51^{1}$ & 169762 & Dachshund & Macho & 6 & 6,7 & T12-13 Extrusão à esquerda \\
52 & 166472 & Poodle & Macho & 1 & 3,4 & T12-13 \\
53 & 161485 & Lhasa apso & Fêmea & 4 & 8 & L2-3 \\
54 & 163492 & Dachshund & Macho & 6 & 7,7 & T10-11; T11-12; T12-13 \\
55 & 163193 & Cocker spaniel & Macho & 4 & 12 & T12-13; T11-12 \\
56 & 164286 & Dachshund & Fêmea & 3 & 8,3 & T13-L1 \\
57 & 166361 & Dachshund & Macho & 7 & 11 & T11-12 \\
58 & 163071 & Cocker spaniel & Macho & 8 & 13 & - \\
59 & 169458 & SRD & Fêmea & 6 & 12,3 & T9-10; T10-11; T11-12 \\
60 & 169480 & Poodle & Macho & 6 & 2,1 & T11-12;T12-13 \\
61 & 166300 & Dachshund & Macho & 7 & 8,1 & T12-13 \\
\hline
\end{tabular}

${ }^{1}$ Animais que não retornaram a locomoção e foram encaminhados à cirurgia e excluídos da análise quanto ao tempo de retorno a locomoção em dias do grupo de animais com grau 3 e 4

*Animal que participou da análise dos resultados duas vezes, participando do grupo 5 e grupo 4 após retorno da sensibilidade dolorosa profunda

"Animais que foram submetidos a exames de tomografia computadorizada e mielografia

Quadro 2 - Número do animal, número de identificação no Hospital Veterinário, raça, sexo, idade (em anos), peso (em quilogramas) e local da lesão detectadas por imagens radiográficas e/ou tomografia computadorizada e mielografia dos cães atendidos durante o estudo (41 a 61) - FMVZ/USP - São Paulo, 2006 


\section{APÊNDICE C}

\begin{tabular}{|c|c|c|c|c|}
\hline $\begin{array}{c}\text { Etapas de } \\
\text { análise }\end{array}$ & $\begin{array}{c}\text { Primeira } \\
\text { avaliação }\end{array}$ & $\begin{array}{c}\text { Sétima } \\
\text { Avaliação }\end{array}$ & $\begin{array}{c}\text { Décima quarta } \\
\text { Avaliação }\end{array}$ & $\begin{array}{c}\text { Última } \\
\text { Avaliação }\end{array}$ \\
\hline Cão $n^{\circ}$ & Momento 0 & Momento 7 & Momento 14 & Momento Final \\
\hline 1 & 20 & 22 & 22,5 & 23 \\
\hline 2 & 21 & 21 & 21,5 & 21,5 \\
\hline 3 & 22 & 22 & 22,5 & 23 \\
\hline 4 & 17 & 19 & 23 & 23 \\
\hline 5 & 16 & 21 & 21 & 22 \\
\hline 6 & 19 & 20 & 20 & 23 \\
\hline 7 & 21 & 23 & 23 & 23 \\
\hline 8 & 21 & 21 & 21 & 22 \\
\hline 9 & 21 & 21 & 22 & 23 \\
\hline 10 & 22,5 & 23 & 23 & 23 \\
\hline 11 & 10 & 17 & 20 & 22 \\
\hline 12 & 11 & 21 & 21 & 23 \\
\hline 13 & 10 & 8 & 10,5 & 22 \\
\hline 14 & 12 & 13 & 20 & 22 \\
\hline 15 & 6 & 13 & 17 & 22,5 \\
\hline 16 & 9 & 11 & 18 & 20,5 \\
\hline 17 & 1 & 1 & 1 & 22,5 \\
\hline 18 & 4 & 4,5 & 8,5 & 14 \\
\hline 19 & 1 & 3,5 & 4,5 & 12 \\
\hline 20 & 9 & 20 & 20,5 & 21 \\
\hline 21 & 8 & 10 & 12 & 22 \\
\hline 22 & 14 & 20 & 22 & 22 \\
\hline 23 & 11 & 14 & 16 & 21 \\
\hline 24 & 13 & 14 & 18,5 & 18,5 \\
\hline 25 & 5 & 14 & 20 & 21,5 \\
\hline 26 & 8 & 9 & 10 & 15 \\
\hline 27 & 4 & DESISTÊNCIA & - & - \\
\hline 28 & 1 & EUTANÁSIA & - & - \\
\hline 29 & 2 & EUTANÁSIA & - & - \\
\hline 30 & 0 & DESISTÊNCIA & - & - \\
\hline
\end{tabular}

Quadro 3 - Avaliação do estado neurológico com relação a escala funcional numérica total nas diferentes etapas de análise dos cães de número 1 a 30 - FMVZ/USP - São Paulo, 2006 
APÊNDICE D

\begin{tabular}{|c|c|c|c|c|}
\hline $\begin{array}{c}\text { Etapas de } \\
\text { análise }\end{array}$ & $\begin{array}{l}\text { Primeira } \\
\text { avaliação }\end{array}$ & $\begin{array}{c}\text { Sétima } \\
\text { Avaliação }\end{array}$ & $\begin{array}{l}\text { Décima quarta } \\
\text { Avaliação }\end{array}$ & $\begin{array}{c}\text { Última } \\
\text { Avaliação }\end{array}$ \\
\hline Cão $n^{\circ}$ & Momento 0 & Momento 7 & Momento 14 & Momento Final \\
\hline 31 & 11 & 12 & EUTANÁSIA & - \\
\hline 32 & 1 & EUTANÁSIA & - & - \\
\hline 33 & 12 & 12 & 16 & DESISTÊNCIA \\
\hline 34 & 0 & DESISTÊNCIA & - & - \\
\hline 35 & 0 & DESISTÊNCIA & - & - \\
\hline 36 & 21 & 23 & 23 & 23 \\
\hline 37 & 21 & 21,5 & 21,5 & 22 \\
\hline 38 & 19 & 21 & 21 & 21,5 \\
\hline 39 & 21 & 21 & 23 & 23 \\
\hline 40 & 21 & 22 & 23 & 21 \\
\hline 41 & 21 & 17 & 23 & 22,5 \\
\hline 42 & 21 & 20,5 & 21 & 22,5 \\
\hline 43 & 6 & 8 & 17,5 & 20,5 \\
\hline 44 & 8 & 8 & 8 & 21 \\
\hline 45 & 8 & 21 & 21 & 23 \\
\hline 46 & 9 & 10 & 13 & 21,5 \\
\hline 47 & 12 & 13 & 13 & 22 \\
\hline 48 & 8 & 8 & 8 & 21,5 \\
\hline 49 & 4 & 9 & 11 & 10,5 \\
\hline 50 & 9 & 10 & 10 & 13 \\
\hline 51 & 10 & 10 & 15 & 13 \\
\hline 52 & 1 & 11 & 15 & 21 \\
\hline 53 & 2 & 2 & 2 & 2 \\
\hline 54 & 4 & 4 & 4 & 4 \\
\hline 55 & 2,5 & 3 & 2,5 & 2,5 \\
\hline 56 & 2 & 3 & 4 & 6 \\
\hline 57 & 3 & 2 & 2 & 3 \\
\hline 58 & 0 & 1 & 1 & 1 \\
\hline 59 & 11 & DESISTÊNCIA & - & - \\
\hline 60 & 6 & DESISTÊNCIA & - & - \\
\hline 61 & 13 & DESISTÊNCIA & - & - \\
\hline $50^{*}$ & 13 & 13 & 13 & 13 \\
\hline
\end{tabular}

50* Animal que participou duas vezes da análise durante o estudo, classificado no grupo de animais com grau 5 e grau 4

Quadro 4 - Avaliação do estado neurológico com relação a escala funcional numérica total nas diferentes etapas de análise dos cães de número 31 a 61 e número 50*-FMVZ/USP - São Paulo, 2006 
APÊNDICE E

\begin{tabular}{|c|c|c|c|c|c|c|c|}
\hline Cão $n^{\circ}$ & Grau lesão & $\begin{array}{l}\text { Evolução } \\
\text { sintomas }\end{array}$ & $\begin{array}{c}\text { Grupo de } \\
\text { tratamento }\end{array}$ & Tempo loc $^{2}$ & Propriocepção $^{3}$ & $\begin{array}{l}\text { Tempo } \\
\text { cauda }^{4}\end{array}$ & $\begin{array}{l}\text { Tempo } \\
\text { micção }^{5}\end{array}$ \\
\hline 1 & 2 & 0 & acupuntura & - & 7 & - & - \\
\hline 2 & 2 & 45 & acupuntura & - & 7 & - & - \\
\hline 3 & 2 & 45 & acupuntura & - & 31 & - & - \\
\hline 4 & 2 & 30 & acupuntura & - & 11 & - & 15 \\
\hline 5 & 2 & 10 & acupuntura & - & 18 & - & 4 \\
\hline 6 & 2 & 6 & acupuntura & - & 33 & - & 4 \\
\hline 7 & 1 & 60 & acupuntura & - & 21 & - & - \\
\hline 8 & 2 & 22 & acupuntura & - & 34 & - & - \\
\hline 9 & 2 & 10 & acupuntura & - & 7 & - & - \\
\hline 10 & 1 & 60 & acupuntura & - & 7 & - & - \\
\hline 11 & 3 & 15 & acupuntura & 14 & 14 & - & 6 \\
\hline 12 & 3 & 14 & acupuntura & 1 & 14 & - & 5 \\
\hline 13 & 4 & 7 & acupuntura & 14 & 5 & 28 & 26 \\
\hline 14 & 4 & 10 & acupuntura & 8 & 18 & - & - \\
\hline 15 & 4 & 8 & acupuntura & 18 & 19 & 9 & 2 \\
\hline 16 & 4 & 30 & acupuntura & 7 & 27 & - & 27 \\
\hline 17 & 5 & 5 & acupuntura & 8 & 22 & 63 & 28 \\
\hline $18^{\#}$ & 5 & 5 & acupuntura & Insucesso & Insucesso & 21 & Insucesso \\
\hline $19^{\#}$ & 5 & 10 & acupuntura & Insucesso & Insucesso & 38 & Insucesso \\
\hline 20 & 4 & 21 & acupuntura & 3 & 7 & - & - \\
\hline 21 & 5 & 15 & acupuntura & 21 & 27 & - & - \\
\hline 22 & 4 & 20 & acupuntura & 4 & 6 & - & - \\
\hline 23 & 4 & 32 & acupuntura & 20 & 28 & - & - \\
\hline 24 & 3 & 1 & acupuntura & 12 & 21 & - & - \\
\hline 25 & 5 & 28 & acupuntura & 15 & 39 & 6 & - \\
\hline 26 & 5 & 52 & acupuntura & Insucesso & Insucesso & - & - \\
\hline 27 & 5 & 7 & acupuntura & Desistência & Desistência & Desistência & Desistência \\
\hline 28 & 4 & 8 & acupuntura & Desistência & Desistência & Desistência & Desistência \\
\hline 29 & 5 & 7 & acupuntura & Desistência & Desistência & Desistência & Desistência \\
\hline 30 & 5 & 14 & acupuntura & Desistência & Desistência & Desistência & Desistência \\
\hline 31 & 3 & 7 & acupuntura & Desistência & Desistência & Desistência & Desistência \\
\hline 32 & 5 & 4 & acupuntura & Desistência & Desistência & Desistência & Desistência \\
\hline 33 & 4 & 14 & acupuntura & Desistência & Desistência & Desistência & Desistência \\
\hline 34 & 5 & 11 & acupuntura & Desistência & Desistência & Desistência & Desistência \\
\hline 35 & 5 & 7 & acupuntura & Desistência & Desistência & Desistência & Desistência \\
\hline 36 & 2 & 7 & sem acupuntura & - & 8 & - & - \\
\hline 37 & 2 & 21 & sem acupuntura & - & 6 & - & - \\
\hline $38^{*}$ & 2 & 6 & sem acupuntura & - & 7 & 23 & - \\
\hline 39 & 1 & 6 & sem acupuntura & - & 7 & - & - \\
\hline 40 & 2 & 6 & sem acupuntura & - & 8 & - & - \\
\hline
\end{tabular}

${ }^{1}$ Evolução sintomas: tempo em dias do início dos sintomas até a $1^{\mathrm{a}}$ avaliação; ${ }^{2}$ Tempo loc: tempo de retorno a locomoção, mesmo intermitente, em dias; ${ }^{3}$ Propriocepção: tempo em dias de retorno ou melhora propriocepção em pelo menos um membro; ${ }^{4}$ Tempo cauda: tempo em dias de retorno movimentação voluntária da cauda; ${ }^{5}$ Tempo micção: tempo em dias de retorno da micção urinária; ${ }^{18}$ e 19: animais que retornaram com caminhar espinhal; * 38: animal que recidivou sintomas após 4 meses da $1^{\text {a }}$ avaliação

Quadro 5 - Número do animal, grau de lesão de discopatia tóraco-lombar, evolução dos sintomas em dias, grupos de acupuntura e sem acupuntura, tempo de retorno à locomoção, tempo de retorno da propriocepção, tempo de retorno da movimentação cauda e tempo de retorno da micção urinária dos cães de número 1 a 40 - FMVZ/USP São Paulo, 2006 


\section{APÊNDICE F}

\begin{tabular}{|c|c|c|c|c|c|c|c|}
\hline Cão $^{\circ}$ & Grau lesão & $\begin{array}{c}\text { Evolução } \\
\text { sintomas }^{1}\end{array}$ & $\begin{array}{c}\text { Grupo de } \\
\text { tratamento }\end{array}$ & Tempo loc & ${ }^{2}$ Propriocepção $^{3}$ & $\begin{array}{c}\text { Tempo } \\
\text { cauda }^{4}\end{array}$ & $\begin{array}{c}\text { Tempo } \\
\text { micção }^{5}\end{array}$ \\
\hline 41 & 2 & 4 & sem acupuntura & - & 16 & - & 1 \\
\hline 42 & 2 & 3 & sem acupuntura & - & 27 & - & - \\
\hline 43 & 4 & 1 & sem acupuntura & 13 & 29 & 11 & 14 \\
\hline 44 & 4 & 7 & sem acupuntura & 26 & 33 & 20 & 26 \\
\hline 45 & 4 & 1 & sem acupuntura & 5 & 12 & 7 & - \\
\hline 46 & 3 & 6 & sem acupuntura & 23 & Insucesso & 13 & 27 \\
\hline 47 & 4 & 20 & sem acupuntura & 18 & 21 & - & - \\
\hline 48 & 4 & 8 & sem acupuntura & 40 & 43 & - & 23 \\
\hline 49 & 4 & 2 & sem acupuntura & Insucesso & Insucesso & 5 & 12 \\
\hline 50 & 5 & 14 & sem acupuntura & Insucesso & Insucesso & - & - \\
\hline 51 & 4 & 120 & sem acupuntura & Insucesso & Insucesso & - & - \\
\hline 52 & 5 & 4 & sem acupuntura & 18 & 34 & 5 & 7 \\
\hline 53 & 5 & 30 & sem acupuntura & Insucesso & Insucesso & Insucesso & - \\
\hline 54 & 5 & 15 & sem acupuntura & Insucesso & Insucesso & - & - \\
\hline 55 & 5 & 21 & sem acupuntura & Insucesso & Insucesso & - & - \\
\hline 56 & 5 & 12 & sem acupuntura & Insucesso & Insucesso & 49 & - \\
\hline 57 & 5 & 15 & sem acupuntura & Insucesso & Insucesso & - & - \\
\hline 58 & 5 & 6 & sem acupuntura & Insucesso & Insucesso & - & - \\
\hline 59 & 4 & 14 & sem acupuntura & Desistência & Desistência & Desistência & Desistência \\
\hline 60 & 4 & 10 & sem acupuntura & Desistência & Desistência & Desistência & Desistência \\
\hline 61 & 3 & 14 & sem acupuntura & Desistência & Desistência & Desistência & Desistência \\
\hline $50^{*}$ & 4 & 35 & sem acupuntura & Insucesso & Insucesso & - & - \\
\hline
\end{tabular}

${ }^{1}$ Evolução sintomas: tempo em dias do início dos sintomas até a $1^{\text {a }}$ avaliação; ${ }^{2}$ Tempo loc: tempo de retorno a locomoção, mesmo intermitente, em dias; ${ }^{3}$ Propriocepção: tempo em dias de retorno ou melhora propriocepção em pelo menos um membro; ${ }^{4}$ Tempo cauda: tempo em dias de retorno movimentação voluntária da cauda; ${ }^{5}$ Tempo micção: tempo em dias de retorno da micção urinária; * 50: animal que participou duas vezes da análise, como grau 5 e posteriormente grau 4

Quadro 6 - Número do animal, grau de lesão de discopatia tóraco-lombar, evolução dos sintomas em dias, grupos de acupuntura e sem acupuntura, tempo de retorno à locomoção, tempo de retorno da propriocepção, tempo de retorno da movimentação cauda e tempo de retorno da micção urinária dos cães de número 41 a 61 e 50* - FMVZ/USP - São Paulo, 2006 


\section{APÊNDICE G}

\begin{tabular}{|c|c|c|c|c|c|}
\hline \multirow{3}{*}{$\begin{array}{l}\text { Grupo } \\
\text { Cão no }\end{array}$} & \multicolumn{5}{|c|}{ Acupuntura } \\
\hline & \multicolumn{3}{|c|}{ Nível de Recuperação } & \multirow{2}{*}{$\begin{array}{c}\text { Medicação prévia a } 1^{\mathrm{a}} \\
\text { avaliação ou Momento } 0\end{array}$} & \multirow[b]{2}{*}{$\begin{array}{c}\text { Medicação a partir } 1^{a} \\
\text { avaliação ou Momento } 0\end{array}$} \\
\hline & Micção $^{1}$ & Prop $^{2}$ & Locomoção $^{3}$ & & \\
\hline 1 & - & $\mathrm{RT}$ & $\mathrm{RT}$ & sem medicação & prednisona, dipirona \\
\hline 2 & - & RB & RB & prednisona, dipirona, ranitidina & prednisona \\
\hline 3 & - & RT & RT & $\begin{array}{c}\text { prednisona, dipirona, ranitidina, } \\
\text { citoneurim }\end{array}$ & sucralfato, ranitidina \\
\hline 4 & RT & RT & RT & dipirona, cloridrato de tramadol & dipirona, cloridrato de tramadol \\
\hline 5 & RT & $\mathrm{RB}$ & $\mathrm{RB}$ & prednisona, enrofloxacin & prednisona, Xiao Huo Luo Dan \\
\hline 6 & RT & RT & RT & $\begin{array}{c}\text { prednisona, ampicilina, dipirona, } \\
\text { metoclopramida }\end{array}$ & $\begin{array}{c}\text { prednisona, dipirona, cloridrato de } \\
\text { tramadol, ranitidina }\end{array}$ \\
\hline 7 & - & RT & RT & $\begin{array}{l}\text { meloxicam, cloridrato de tramadol, } \\
\text { dipirona e brometo de } \\
\text { Nbutilescopolamina }\end{array}$ & $\begin{array}{c}\text { cloridrato de tramadol, dipirona, } \\
\text { enrofloxacin }\end{array}$ \\
\hline 8 & - & $\mathrm{RD}$ & $\mathrm{RD}$ & $\begin{array}{c}\text { prednisona, dipirona, prometazina, } \\
\text { adifenina }\end{array}$ & dipirona \\
\hline 9 & - & $\mathrm{RT}$ & RT & meloxicam, prednisona, dipirona & dipirona \\
\hline 10 & - & $\mathrm{RB}$ & RT & $\begin{array}{c}\text { prednisona, cloridrato de tramadol, } \\
\text { dipirona }\end{array}$ & cloridrato de tramadol, dipirona \\
\hline 11 & - & $\mathrm{RB}$ & RB & $\begin{array}{l}\text { prednisona, vitamina complexo } \mathrm{B}, \\
\text { dipirona }\end{array}$ & prednisona, dipirona \\
\hline 12 & RT & RT & RT & $\begin{array}{c}\text { prednisona, vitamina complexo B, } \\
\text { omeprazol }\end{array}$ & prednisona, dipirona \\
\hline 13 & RB & $\mathrm{RB}$ & RB & $\begin{array}{c}\text { meloxicam, vitamina complexo B, } \\
\text { corticosteróide injetável }\end{array}$ & $\begin{array}{l}\text { prednisona, cloridrato de tramadol, } \\
\text { dipirona, }\end{array}$ \\
\hline 14 & - & RT & RB & dexametazona, vitamina complexo B & prednisona, dipirona, ranitidina \\
\hline 15 & $\mathrm{RB}$ & RT & RT & dexametazona, ácido acetil salicílico & $\begin{array}{c}\text { prednisona, dipirona, cloridrato de } \\
\text { tramadol, ranitidina }\end{array}$ \\
\hline 16 & RB & $\mathrm{RB}$ & RB & $\begin{array}{c}\text { dexametazona, vitamina complexo B, } \\
\text { succinato de metil prednisolona }\end{array}$ & dipirona \\
\hline 17 & RB & RB & RB & $\begin{array}{c}\text { dexametazona, vitamina complexo B, } \\
\text { enrofloxacin, prednisona }\end{array}$ & $\begin{array}{l}\text { prednisona, dipirona, cloridrato de } \\
\text { tramadol }\end{array}$ \\
\hline 18 & SR & SR & $\mathrm{RD}$ & $\begin{array}{l}\text { prednisona, dipirona, cloridrato de } \\
\text { tramadol }\end{array}$ & $\begin{array}{c}\text { prednisona, dipirona, cloridrato de } \\
\text { tramdol, ranitidina }\end{array}$ \\
\hline 19 & SR & $\mathrm{RD}$ & $\mathrm{RD}$ & dexametazona, dipirona & $\begin{array}{c}\text { prednisona, dipirona, cloridrato de } \\
\text { tramadol }\end{array}$ \\
\hline 20 & - & $\mathrm{RB}$ & RB & $\begin{array}{l}\text { prednisona, dipirona, cloridrato de } \\
\text { tramadol }\end{array}$ & dipriona, cloridrato de tramadol \\
\hline 21 & - & $\mathrm{RB}$ & RB & $\begin{array}{c}\text { prednisona, vitamina complexo } \mathrm{B}, \\
\text { dipirona }\end{array}$ & prednisona, dipirona \\
\hline 22 & - & RT & RB & prednisona, dipirona, cefalexina & prednisona, dipirona, ranitidina \\
\hline 23 & - & $\mathrm{RB}$ & RB & $\begin{array}{l}\text { prednisona, cloridrato de tramadol, } \\
\text { dipirona }\end{array}$ & dipirona \\
\hline 24 & - & $\mathrm{RB}$ & RB & $\begin{array}{c}\text { cloridrato de tramado, corticóide } \\
\text { injetável }\end{array}$ & Xiao Huo Luo Dan \\
\hline 25 & - & $\mathrm{RB}$ & RB & prednisona & $\begin{array}{l}\text { Xiao Huo Luo Dan, cloridrato de } \\
\text { tramadol, dipirona }\end{array}$ \\
\hline 26 & - & SR & SR & $\begin{array}{c}\text { vitamina complexo B e } \mathrm{C} \text {, } \\
\text { dexametazona }\end{array}$ & prednisona, dipirona \\
\hline
\end{tabular}

${ }^{1}$ Micção: grau de recuperação da capacidade de micção urinária; ${ }^{2}$ Prop: grau de recuperação do retorno ou melhora da propriocepção; ${ }^{3}$ Locomoção: grau de recuperação da locomoção, RT: recuperação total; RB: recuperação boa; RD: recuperação discreta; SR: sem recuperação

Quadro 7 - Número do animal, nível de recuperação em relação a capacidade de micção, retorno ou melhora da propriocepção, locomoção, medicações associadas no tratamento antes da $1^{\mathrm{a}}$ avaliação e a partir da $1^{\mathrm{a}}$ avaliação, dos animais 1 a 26 do grupo tratamento com acupuntura - FMVZ/USP - São Paulo, 2006 
APÊNDICE H

\begin{tabular}{|c|c|c|c|c|c|}
\hline \multirow{3}{*}{$\begin{array}{l}\text { Grupo } \\
\text { Cão no }\end{array}$} & \multicolumn{5}{|c|}{ Sem acupuntura } \\
\hline & \multicolumn{3}{|c|}{ Nível de Recuperação } & \multirow{2}{*}{$\begin{array}{c}\text { Associação de Medicações } \\
\text { prévia a } 1^{\text {a }} \text { avaliação }\end{array}$} & \multirow{2}{*}{$\begin{array}{c}\text { Associação de Medicações a } \\
\text { partir } 1^{\text {a }} \text { avaliação }\end{array}$} \\
\hline & Micção ${ }^{1}$ & Prop ${ }^{2}$ & Locomoção $^{3}$ & & \\
\hline 36 & - & RT & RT & $\begin{array}{l}\text { meloxicam, dexametazona, vitamina } \\
\text { complexo B }\end{array}$ & prednisona, dipirona \\
\hline 37 & - & RT & RB & dexametazona e após prednisona & dipirona, enrofloxacin \\
\hline 38 & - & RT & $\mathrm{RB}$ & $\begin{array}{l}\text { prednisona, dipirona, cloridrato de } \\
\text { tramadol }\end{array}$ & prednisona, dipirona, ranitidina \\
\hline 39 & - & RT & RB & prednisona & prednisona \\
\hline 40 & - & RT & RB & dipirona & prednisona, dipirona \\
\hline 41 & - & RB & RB & $\begin{array}{c}\text { prednisona, succinato de metil } \\
\text { prednisolona }\end{array}$ & prednisona, dipirona, ranitidina \\
\hline 42 & - & RB & RB & meloxicam, condroitina, prednisona & prednisona, dipirona \\
\hline 43 & RB & RB & RB & prednisona & prednisona, ranitidina, dipirona \\
\hline 44 & RT & RB & $\mathrm{RB}$ & prednisona, condroitina, meloxicam & prednisona, dipirona \\
\hline 45 & - & $\mathrm{RT}$ & $\mathrm{RB}$ & - & $\begin{array}{c}\text { succinato de metil prednisolona, } \\
\text { prednisona, cloridrato de tramadol, } \\
\text { dipirona }\end{array}$ \\
\hline 46 & RB & SR & RB & $\begin{array}{l}\text { prednisona, dipirona, vitamina } \\
\text { complexo B }\end{array}$ & prednisona, dipirona \\
\hline 47 & - & RB & RB & carproflan, prednisona, dipirona & prednisona, dipirona \\
\hline 48 & $\mathrm{RB}$ & $\mathrm{RT}$ & RB & $\begin{array}{c}\text { cetoprofeno, dexametazona, vitamina } \\
\text { complexo B }\end{array}$ & prednisona, dipirona \\
\hline 49 & RB & SR & SR & $\begin{array}{l}\text { succinato de metil prednisolona, } \\
\text { prednisona }\end{array}$ & $\begin{array}{c}\text { prednisona, dipirona, cloridrato de } \\
\text { tramadol, ranitidina }\end{array}$ \\
\hline 50 & - & SR & SR & $\begin{array}{c}\text { dexametazona, dipirona, cloridrato de } \\
\text { tramadol } \\
\end{array}$ & prednisona, dipirona \\
\hline 51 & - & SR & SR & $\begin{array}{c}\text { prednisona, cloridrato de tramadol, } \\
\text { dipirona }\end{array}$ & $\begin{array}{c}\text { cloridrato de tramadol, meloxicam, } \\
\text { dipirona }\end{array}$ \\
\hline 52 & RT & RB & RB & dexametazona & prednisona, dipirona, ranitidina \\
\hline 53 & $\mathrm{SR}$ & $\mathrm{SR}$ & SR & $\begin{array}{c}\text { prednisona, dipirona, condroitina, } \\
\text { hialuronidase }\end{array}$ & prednisona, hialuronidase \\
\hline 54 & $\mathrm{SR}$ & SR & SR & prednisona, vitamina complexo B & prednisona \\
\hline 55 & SR & SR & SR & dexametazona & prednisona, dipirona, enrofloxacin \\
\hline 56 & SR & SR & SR & prednisona & prednisona, dipirona \\
\hline 57 & SR & SR & SR & $\begin{array}{c}\text { prednisona, enrofloxacin, vitamina } \\
\text { complexo B e C, dexametazona, } \\
\text { dipirona e brometo de } \\
\text { Nbutilescopolamina }\end{array}$ & prednisona, dipirona \\
\hline 58 & $\mathrm{SR}$ & SR & SR & $\begin{array}{c}\text { prednisona, vitamina complexo B, } \\
\text { enrofloxacin }\end{array}$ & $\begin{array}{c}\text { prednisona, cloridrato de tramadol, } \\
\text { dipirona }\end{array}$ \\
\hline
\end{tabular}

${ }^{1}$ Micção: grau de recuperação da capacidade de micção urinária; ${ }^{2}$ Prop: grau de recuperação do retorno ou melhora da propriocepção; ${ }^{3}$ Locomoção: grau de recuperação da locomoção; RT: recuperação total; RB: recuperação boa; RD: recuperação discreta; SR: sem recuperação; ${ }^{*} 50$ : Animal participante duas vezes da análise, no grupo de grau 4 e 5.

Quadro 8 - Número do animal, nível de recuperação em relação à capacidade de micção, retorno ou melhora da propriocepção, locomoção, medicações associadas no tratamento antes da $1^{\text {a }}$ avaliação e a partir da $1^{\text {a }}$ avaliação, dos animais 36 a 58 do grupo tratamento sem acupuntura - FMVZ/USP - São Paulo, 2006 


\section{APÊNDICE I}

\begin{tabular}{|c|c|c|c|c|c|c|}
\hline Cão $n^{\circ}$ & $\begin{array}{c}n^{\circ} \text { sessões } \\
\text { prop }^{1}\end{array}$ & $\begin{array}{l}n^{0} \text { total } \\
\text { sessões }^{2} \\
\end{array}$ & Eletroacupuntura $^{3}$ & Acupuntura $^{4}$ & Sonol $^{5}$ & Saliv $^{6}$ \\
\hline 1 & 3 & 4 & $\begin{array}{c}\text { B20 e B23; E36 e R3/B60; VG1 e Bai } \\
\text { Hui lombar }\end{array}$ & ID3; B62 & $\operatorname{sim}$ & $\operatorname{sim}$ \\
\hline 2 & 4 & 4 & $\begin{array}{c}\text { B20 e B23; E36 e R3/B60; Bai Hui } \\
\text { lombar e VB30 }\end{array}$ & ID3; B62 & $\operatorname{sim}$ & não \\
\hline 3 & 3 & 4 & $\begin{array}{c}\text { B20 e B23; E36 e R3/B60; Bai Hui } \\
\text { lombar e VB30 }\end{array}$ & ID3; B62 & $\operatorname{sim}$ & não \\
\hline $4^{*}$ & 2 & 4 & $\begin{array}{c}\text { B20 e B23; E36 e R3/B60; Bai Hui } \\
\text { lombar e VB30 }\end{array}$ & ID3; B62 & $\operatorname{sim}$ & não \\
\hline 5 & 3 & 5 & $\begin{array}{c}\text { B20 e B23; E36 e R3/B60; VG1 e Bai } \\
\text { Hui lombar }\end{array}$ & ID3; B62 & $\operatorname{sim}$ & $\operatorname{sim}$ \\
\hline 6 & 5 & 9 & $\begin{array}{c}\text { B20 e B23; E36 e R3/B60; VG1 e Bai } \\
\text { Hui lombar }\end{array}$ & ID3; B62 & não & não \\
\hline 7 & 3 & 5 & $\begin{array}{c}\text { B20 e B23; E36 e R3/B60; Bai Hui } \\
\text { lombar e VB30 }\end{array}$ & ID3; B62 & $\operatorname{sim}$ & $\operatorname{sim}$ \\
\hline 8 & 6 & 10 & $\begin{array}{c}\text { B20 e B23; E36 e R3/B60; Bai Hui } \\
\text { lombar e VB30 }\end{array}$ & ID3; B62 & $\operatorname{sim}$ & não \\
\hline 9 & 3 & 4 & $\begin{array}{c}\text { B20 e B23; E36 e R3/B60; Bai Hui } \\
\text { lombar e VB30 }\end{array}$ & ID3; B62 & $\operatorname{sim}$ & não \\
\hline 10 & 2 & 3 & $\begin{array}{c}\text { B20 e B23; E36 e R3/B60; Bai Hui } \\
\text { lombar e VB30 }\end{array}$ & ID3; B62 & não & $\operatorname{sim}$ \\
\hline
\end{tabular}

${ }^{1} \mathbf{n}^{\mathbf{0}}$ sessões prop: número de sessões de acupuntura realizadas até observação retorno ou melhora propriocepção de pelo menos um membro; ${ }^{2}$ $\mathbf{n}^{0}$ total sessões: número total de sessões realizadas; ${ }^{3}$ Eletroacupuntura: acupontos onde foi utilizado eletroacupuntura percutânea; ${ }^{4}$ Acupuntura: acupontos onde foi utilizada acupuntura clássica com inserção agulhas; ${ }^{5}$ Sonol: presença de sonolência durante pelo menos uma sessão; ${ }^{6}$ Saliv: presença de salivação ou secreção serosa ocular durante pelo menos uma sessão; ${ }^{7} \mathbf{n}^{0}$ sessões loc: número de sessões de acupuntura realizadas até observação de retorno a locomoção; $4^{*}$ : animal com diagnóstico de hiperadrenocorticismo

Quadro 9 - Número do animal; número de sessões para reabilitação total ou parcial da propriocepção; número total de sessões; acupontos com eletroacupuntura; acupontos com inserção simples da agulha; presença ou ausência de sonolência e salivação ou secreção serosa ocular dos animais do grupo acupuntura com grau 1 ou 2 de lesão (animais 1 a 10) - FMVZ/USP - São Paulo, 2006 


\section{APÊNDICE J}

\begin{tabular}{|c|c|c|c|c|c|c|c|}
\hline Cão $n^{\circ}$ & $\begin{array}{c}n^{0} \text { sessões } \\
\operatorname{loc}^{7}\end{array}$ & $\begin{array}{c}n^{0} \text { total } \\
\text { sessões }\end{array}$ & Eletroacupuntura $^{3}$ & Acupuntura $^{4}$ & Sonol $^{5}$ & Saliv $^{6}$ & $\begin{array}{c}n^{\circ} \text { sessões }^{\text {prop }^{1}} \\
\end{array}$ \\
\hline 11 & 3 & 4 & $\begin{array}{l}\text { B20 e B23; E36 e R3/B60; } \\
\text { VG1 e Bai Hui lombar }\end{array}$ & ID3; B62 & $\operatorname{sim}$ & $\operatorname{sim}$ & 2 \\
\hline 12 & 1 & 10 & $\begin{array}{l}\text { B20 e B23; E36 e R3/B60; } \\
\text { VG1 e Bai Hui lombar }\end{array}$ & ID3; B62 & $\operatorname{sim}$ & $\operatorname{sim}$ & 2 \\
\hline 13 & 3 & 10 & $\begin{array}{l}\text { B20 e B23; E36 e R3/B60; } \\
\text { VG1 e Bai Hui lombar }\end{array}$ & ID3; B62 & $\operatorname{sim}$ & não & 1 \\
\hline 14 & 2 & 5 & $\begin{array}{l}\text { B20 e B23; E36 e R3/B60; } \\
\text { VG1 e Bai Hui lombar }\end{array}$ & ID3; B62 & $\operatorname{sim}$ & não & 3 \\
\hline 15 & 3 & 14 & $\begin{array}{l}\text { B20 e B23; E36 e R3/B60; } \\
\text { VG1 e Bai Hui lombar }\end{array}$ & ID3; B62 & $\operatorname{sim}$ & não & 3 \\
\hline 16 & 2 & 10 & $\begin{array}{l}\text { B20 e B23; E36 e R3/B60; } \\
\text { VG1 e Bai Hui lombar }\end{array}$ & ID3; B62 & $\operatorname{sim}$ & não & 4 \\
\hline 20 & 1 & 5 & $\begin{array}{l}\text { B20 e B23; E36 e R3/B60; } \\
\text { VG1 e Bai Hui lombar }\end{array}$ & IG4 & não & não & 1 \\
\hline $22^{\#}$ & 1 & 5 & $\begin{array}{l}\text { Não realizado } \\
\text { eletroacupuntura }\end{array}$ & $\begin{array}{c}\text { IG4; B62; R3/B60; } \\
\text { E36; B20; B23; } \\
\text { Bai Hui lombar }\end{array}$ & $\operatorname{sim}$ & não & 1 \\
\hline 23 & 3 & 4 & $\begin{array}{l}\text { B20 e B23; E36 e R3/B60; } \\
\text { VG1 e Bai Hui lombar }\end{array}$ & ID3; B62 & $\operatorname{sim}$ & $\operatorname{sim}$ & 3 \\
\hline 24 & 3 & 4 & $\begin{array}{l}\text { B23 e B20 ou B25; E36 e } \\
\text { R3/B60; VG1 e Bai Hui } \\
\text { lombar ou VB30 }\end{array}$ & ID3; B62 & $\operatorname{sim}$ & não & 4 \\
\hline
\end{tabular}

${ }^{1} \mathbf{n}^{\mathbf{0}}$ sessões prop: número de sessões de acupuntura realizadas até observação retorno ou melhora propriocepção de pelo menos um membro; ${ }^{2} \mathbf{n}^{\mathbf{0}}$ total sessões: número total de sessões realizadas; ${ }^{3}$ Eletroacupuntura: acupontos onde foi utilizado eletroacupuntura percutânea; ${ }^{4}$ Acupuntura: acupontos onde foi utilizada acupuntura clássica com inserção agulhas; ${ }^{5}$ Sonol: presença de sonolência durante pelo menos uma sessão; ${ }^{6}$ Saliv: presença de salivação ou secreção serosa ocular durante pelo menos uma sessão; ${ }^{7} \mathbf{n}^{\mathbf{0}}$ sessões loc: número de sessões de acupuntura realizadas até observação de retorno a locomoção; $22^{\#}$ : animal com diagnóstico provável de aplasia medular

Quadro 10 - Número do animal; número de sessões para reabilitação total ou parcial da propriocepção; número total de sessões; acupontos com eletroacupuntura; acupontos com inserção simples da agulha; presença ou ausência de sonolência e salivação ou secreção serosa ocular dos animais do grupo acupuntura com grau 3 ou 4 de lesão (animais 11 a 16;20;22 a 24) - FMVZ/USP - São Paulo, 2006 
APÊNDICE K

\begin{tabular}{|c|c|c|c|c|c|c|c|}
\hline Cão $n^{\circ}$ & $\begin{array}{c}\mathrm{n}^{\circ} \text { sessões } \\
\operatorname{loc}^{1}\end{array}$ & $\begin{array}{l}n^{0} \text { total } \\
\text { sessões }^{2} \\
\end{array}$ & Eletroacupuntura $^{3}$ & Acupuntura $^{4}$ & Sonol $^{5}$ & Saliv $^{6}$ & $\begin{array}{c}n^{0} \text { sessões } \\
\text { prop }^{7}\end{array}$ \\
\hline 17 & 8 & 14 & $\begin{array}{l}\text { B20 e B23; E36 e R3/B60; } \\
\text { VG1 e Bai Hui lombar }\end{array}$ & ID3; B62 & $\operatorname{sim}$ & não & 7 \\
\hline 18 & - & 8 & $\begin{array}{l}\text { B20 e B23; E36 e R3/B60; } \\
\text { VG1 e Bai Hui lombar }\end{array}$ & ID3; B62 & $\operatorname{sim}$ & não & - \\
\hline 19 & - & 18 & $\begin{array}{l}\text { B20 e B23; E36 e R3/B60; } \\
\text { VG1 e Bai Hui lombar }\end{array}$ & ID3; B62 & sim & não & - \\
\hline 21 & 3 & 7 & $\begin{array}{l}\text { B20 e B23; E36 e R3/B60; } \\
\text { VG1 e Bai Hui lombar }\end{array}$ & ID3; B62 & não & não & 4 \\
\hline 25 & - & 9 & $\begin{array}{l}\text { B23 e B25; E36 e R3/B60; } \\
\text { VG1 e Bai Hui lombar }\end{array}$ & ID3; B62 & $\operatorname{sim}$ & não & 6 \\
\hline 26 & 4 & 8 & $\begin{array}{l}\text { B20 e B23; E36 e R3/B60; } \\
\text { VG1 e Bai Hui lombar }\end{array}$ & ID3; B62 & não & não & - \\
\hline
\end{tabular}

${ }^{1} \mathbf{n}^{\mathbf{0}}$ sessões loc: número de sessões de acupuntura realizadas até observação do retorno da locomoção; ${ }^{2} \mathbf{n}^{\mathbf{0}}$ total sessões: número total de sessões realizadas; ${ }^{3}$ Eletroacupuntura: acupontos onde foi utilizado eletroacupuntura percutânea; ${ }^{4}$ Acupuntura: acupontos onde foi utilizada acupuntura clássica com inserção agulhas; ${ }^{5}$ Sonol: presença de sonolência durante pelo menos uma sessão; ${ }^{6}$ Saliv: presença de salivação ou secreção serosa ocular durante pelo menos uma sessão; ${ }^{7} \mathbf{n}^{\mathbf{0}}$ sessões prop: número de sessões de acupuntura realizadas até observação retorno ou melhora propriocepção de pelo menos um membro

Quadro 11 - Número do animal; número de sessões para reabilitação total ou parcial da propriocepção; número total de sessões; acupontos com eletroacupuntura; acupontos com inserção simples da agulha; presença ou ausência de sonolência e salivação ou secreção serosa ocular dos animais do grupo acupuntura com grau 5 de lesão (animais 17 a 19; $21 ; 25$ e 26) - FMVZ/USP - São Paulo, 2006 